\author{
UNIVERSIDADE DE SÃO PAULO \\ ESCOLA DE COMUNICAÇÃO E ARTES \\ PROGRAMA DE PÓS-GRADUAÇÃO EM MÚSICA
}

ANA ISABEL FERREIRA REBELLO

SEMELHANÇAS E DISPARIDADES NO ENSINO E NA EXEÇUÇÃO DA VIOLA E DO VIOLINO

SÃO PAULO 


\author{
UNIVERSIDADE DE SÃO PAULO \\ ESCOLA DE COMUNICAÇÃO E ARTES \\ PROGRAMA DE PÓS-GRADUAÇÃO EM MÚSICA
}

ANA ISABEL FERREIRA REBELLO

\title{
SEMELHANCCAS E DISPARIDADES NO ENSINO E NA EXECUÇÃO DA VIOLA E DO VIOLINO
}

Dissertação apresentada ao Programa de PósGraduação em Música da Universidade de São Paulo como requisito parcial para obtenção do título de Mestre em Artes.

Área: Musicologia

Escola de Comunicações e Artes

Orientador: Prof. Dr. Sérgio Cascapera.

SÃO PAULO 
Rebello, Ana Isabel Ferreira.

Semelhanças e disparidades no ensino e na execução da viola e do violino/Ana Isabel Ferreira Rebello - São Paulo: [s.n] 2011.

$108 \mathrm{f}$.

Orientador: Prof. Dr. Sérgio Cascapera

Dissertação [Mestrado] - Universidade de São Paulo, Escola de Comunicação e Arte, São Paulo, 2011.

Similarities and disparities in education and implementation of the violin and viola.

1. Viola, 2. Violino, 3. Técnica, 4. Diferenças, 5. Pedagogia. I. Título 


\section{ANA ISABEL FERREIRA REBELLO}

\section{SEMELHANÇAS E DISPARIDADES NO ENSINO E NA EXEÇUÇÃO DA VIOLA E DO VIOLINO}

São Paulo, de agosto de 2011.

Prof(a). Dr(a).

Prof(a). Dr(a). 


\section{AGRADECIMENTOS}

À minha mãe (em memória), pelo apoio que sempre me proporcionou.

Ao meu pai pela colaboração prestada.

Ao meu orientador, Prof. Dr. Sérgio Cascapera, pelas sugestões apresentadas para as pesquisas, pela firme orientação e pela paciência sempre presente.

À Prof. Dra. Eliane Tokeshi, pelo grande auxílio.

Aos amigos que colaboraram com idéias e incentivos. 


\section{RESUMO}

A viola e o violino são instrumentos aparentemente semelhantes, tanto em seu formato físico quanto na maneira de tocar. Entretanto, apesar dessas semelhanças, são dois instrumentos distintos no que concerne à produção de som, o que acarreta em disparidades paradoxalmente sutis na execução de ambos os instrumentos.

A técnica e método de ensino específicos da viola vieram a ser aprimorados somente no início do século XX, como conseqüência da valorização do instrumento.

Com esse trabalho pretende-se ampliar o conhecimento dessas diferenças para que haja maior conscientização dos professores e instrumentistas ao ministrar aulas tanto de violino quanto de viola.

Palavras-chave: Viola, Violino, Técnica, Diferenças, Pedagogia, Semelhanças, Execução. 


\begin{abstract}
The viola and the violin are similar instruments, in shape as much as in its way of playing. However, besides all those similarities, they are two distinct instruments in what are related to the sound production, and it results in subtle differences in playing both instruments.

The specific viola technique and teaching method was improved just at the beginning of the 20th century, as consequence of the instrument valorization.

With this work, we intend to increase the knowledge of those differences to increase the teachers and players knowledge to give violin and viola classes.
\end{abstract}

Keywords: Viola, Violin, Technique, Differences, Pedagogy, Similarities, implementation. 


\section{LISTA DE FIGURAS}

Figura 1 - Nomenclatura do violino

Figura 2 - Diferenças entre o violino barroco (Stainer, 1668) e o contemporâneo (J.B.Vuillaume, 1867).

Figura 3 - (a) arco barroco; (b) arco clássico e (c) arco moderno, respectivamente

Figura 4 - Nove estágios no desenvolvimento do arco do violino (17561820)

Figura 5 - Violino e Viola. 26

Figura 6 - Diagrama de forças. 29

Figura 7 - Posição correta... 39

Figura 8 - Posições incorretas. 39

Figura 9 - Mão na primeira posição 40

Figura 10 - Mão na terceira posição 40

Figura 11 - A forma da mão 40

Figura 12 - Posições corretas. 41

Figura 13 - Posições incorretas......................................................... 41

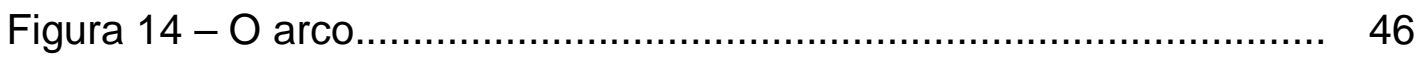

Figura 15 - Forma de onda de saída.............................................. 51

Figura 16 - Escola franco-belga de arco............................................ 54

Figura 17 - Algumas maneiras de segurar o arco................................ 55

Figura 18 - Força $x$ distância............................................................ 57

Figura 19 - Posição da mão no talão, meio e ponta do arco.................. 59

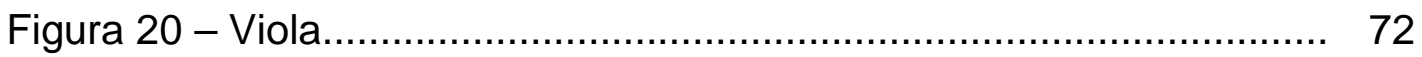

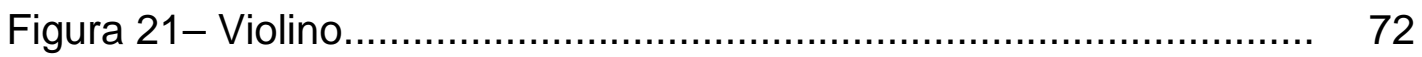

Figura 22 - $1^{\circ}$ mov. Cadência, comp 11-12 com scordatura..................... 84

Figura 23 - $1^{\circ}$ mov. Cadência, comp. 11-12 sem scordatura................... 84

Figura 24- 3o mov. Cadência, comp. 279-282 com scordatura............... 84

Figura 25 - 3으. mov. Cadência, comp. 279-282 sem scordatura................ 84

Figura 26 - $1^{\circ}$ mov. Compassos 211-212 com scordatura....................... 85

Figura 27 - 1ํㅡ. mov. Compassos 211-212 sem scordatura...................... 85 
Figura 28 - $1^{\circ}$ mov. Compassos 321-323 com scordatura...................... 85

Figura 29 - $1^{\circ}$ mov. Compassos 321-323 sem scordatura...................... 85

Figura 30 - $1^{\circ}$ mov. Compassos 156-158 com scordatura...................... 85

Figura 31 - $1^{\circ}$ mov. Compassos 156-158 sem scordatura....................... 85

Figura 32 - 3ำ mov. Compassos 435-439 com scordatura....................... 86

Figura 33 - 3ำ mov. Compassos 435-439 sem scordatura....................... 86 


\section{LISTA DE TABELAS}

Tabela 1 - Violino versus Viola............................................................ 28

Tabela 2 - Comparação dos comprimentos e volumes da caixa de ressonância do violino e da viola............................................................ 32

Tabela 3 - Cordas Jargar com centro de aço (em mm)........................ 45 


\section{SUMÁRIO}

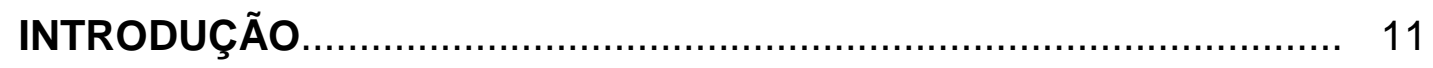

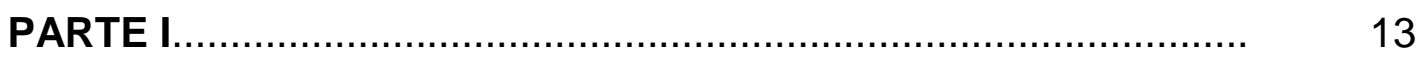

Capítulo 1 - O Violino e a Viola ...................................................... 13

1.1. O Violino.......................................................................... 13

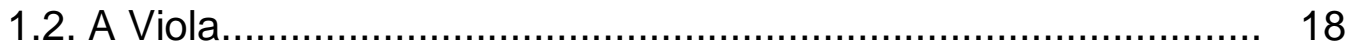

Capítulo 2 - 0 Arco: História e Evolução.......................................... 21

Capítulo 3 - Diferenças entre Violino e Viola................................... 25

3.1. Tamanho dos Instrumentos..................................................... 26

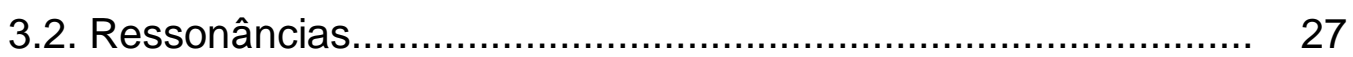

3.3. Espessura das Lâminas...................................................... 34

3.4. Características do Som....................................................... 35

3.4.1. Concepção de sonoridade............................................ 36

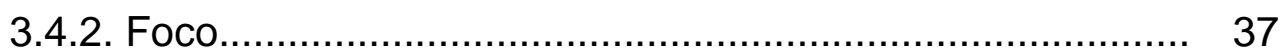

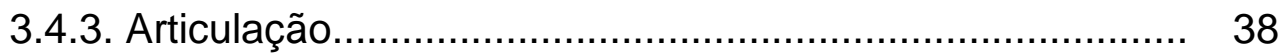

3.4.4. Espessura das cordas................................................. 45

3.5. Arco do Instrumento.......................................................... 46

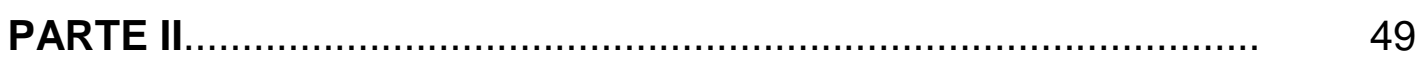

Capítulo 1 - Execução no que concerne à mão direita..................... 49

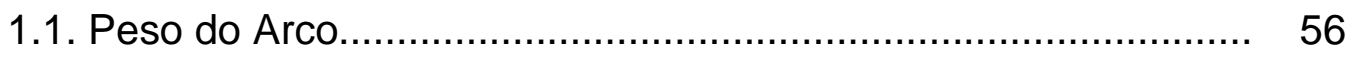

1.2. Distribuição e Velocidade do Arco na Corda.............................. 60

1.3. Ataque e Relaxamento........................................................ 61

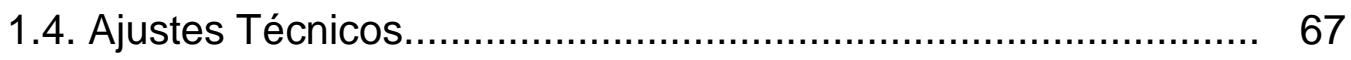

Capítulo 2 - Execução no que concerne à mão esquerda................... 69

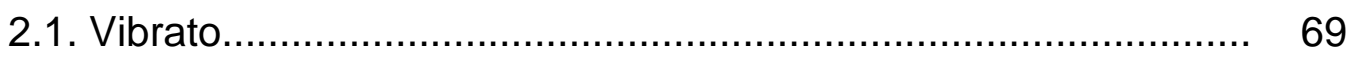

2.2. Dedilhado e Mudança de Posição............................................ 71

2.3. Scordatura.................................................................... 73

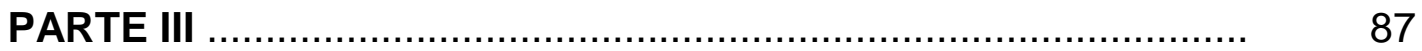


Didática

CONCLUSÃO.

REFERÊNCIAS BIBLIOGRÁFICAS.

ANEXO A - Análise de Livros Específicos..

ANEXO B - Conteúdo Programático.

\title{
INTRODUÇÃO
}

Ligeti (2001), no Prefácio da partitura da Sonata para Viola Solo, diz que:

\begin{abstract}
A viola é na aparência somente um violino grande afinado uma quinta abaixo. Na realidade, os dois instrumentos são mundos à parte. Ambos possuem três cordas em comum, Lá, Ré e Sol. A corda Mi aguda dá ao violino uma luminosidade poderosa som metálico penetrante, que a viola não possui. $O$ violino lidera, a viola permanece em segundo plano. Em compensação, a corda Dó grave concede à viola uma singular aspereza, compacta, de certa forma rouca, com o sabor posterior da madeira, terra e ácido tânico ${ }^{1}$.
\end{abstract}

A viola é pouco maior que o violino, e também, o arco tem tamanho e peso diferentes. Porém, para tocar ambos instrumentos adota-se técnica praticamente idêntica, utilizando as mesmas escolas de arco e mão esquerda e, na maioria das vezes, pelos mesmos métodos, transpostos uma quinta abaixo. É preciso, no entanto, que se valorize essas diferenças para explorar todo o seu potencial sonoro.

Nesse sentido, a fim de abordar o tema proposto, este trabalho encontra-se dividido em seis partes. O capítulo inicial desta primeira parte apresenta um pequeno histórico com as origens dos dois instrumentos, o violino e a viola e sua construção. O segundo capítulo também traz um pequeno histórico sobre o arco do instrumento.

\footnotetext{
1 "The viola is seemingly just a big violin but tuned a fifth lower. In reality the two instruments are worlds apart. They both have three strings in common, the A, D and G string. The high E-string lends the violin a powerful luminosity and metallic penetrating tone which is missing in the viola. The violin leads, the viola remains in the shade. In return the low C-string gives the viola a unique ascerbity, compact, somewhat hoarse, with the aftertaste of Wood, earth and tannic acid."
} 
O terceiro discorre sobre as diferenças físicas entre os dois instrumentos, tratando sobre o tamanho, a ressonância, a espessura das lâminas, as características do som e as diferenças no arco dos instrumentos.

$\mathrm{Na}$ segunda parte serão abordados os aspectos relacionados à execução e suas sutis diferenças entre os dois instrumentos, concernentes à mão direita $e$ esquerda. Sobre a mão direita são tratados os tópicos de peso do arco, distribuição e velocidade do arco na corda, ataque e relaxamento e ajustes técnicos. Sobre a mão esquerda, o vibrato, o dedilhado, a mudança de posição e a scordatura.

A parte final traz uma análise de alguns dos métodos de estudo mais utilizados no estudo e ensino dos dois instrumentos, com uma pequena abordagem histórica. 


\section{PARTE I}

\section{Capítulo 1 - 0 Violino e a Viola: breve descrição}

\section{1- O Violino}

Membro soprano da família dos instrumentos de arco, é um dos instrumentos mais versáteis que já existiram. Além de possuir grande capacidade de sustentação do som e gama de expressão e intensidade, é um instrumento que abrange uma extensão de até quatro oitavas, sendo também capaz de realizar acordes. Essa versatilidade é refletida no repertório solo, camerístico e orquestral, fazendo com que se tornasse um instrumento essencial há mais de três séculos.

Apesar de aparentemente simples, o violino moderno é composto por mais de setenta peças diferentes. Seu corpo é uma caixa oca, consistindo de um tampo superior ligeiramente abaulado e de um fundo de placas planas, unidos por ilhargas ${ }^{2}$ sobre as quais se apóiam. $O$ tampo harmônico ${ }^{3}$ contém duas aberturas acústicas em forma de "f", um estandarte que fixa as cordas e um espelho sem trastes que se projeta pela frente do braço, em cuja extremidade existe uma voluta ornamentada, pela qual originalmente o violino era suspenso.

As cordas têm uma extremidade presa ao estandarte, atravessam um cavalete de madeira, rigorosamente ajustado em altura, espessura, largura e posição, estendendo-se sobre o espelho, e uma pestana de ébano ou marfim, para enrolar-se nas cravelhas, que regulam sua tensão e proporciona a altura adequada do som a ser produzido por cada corda (sol, ré, lá, mi).

Originalmente essas cordas eram feitas de tripa. Atualmente existem cordas de diversos materiais, como aço, tungstênio, prata, ouro e tripa revestida por metal.

Ao serem tangidas com o arco, essas cordas produzem vibrações que são transmitidas para o tampo harmônico e para o tampo inferior, através do cavalete e da alma ${ }^{4}$, dessa forma amplificando o som. Os "efes" formam um sistema acústico subsidiário e contribuem de forma considerável para a ressonância total. O tampo

\footnotetext{
${ }^{2}$ Tábuas que formam os lados das caixas.

${ }^{3}$ Tampo superior do violino.

${ }^{4}$ Peça de madeira colocada verticalmente no interior do corpo do violino, com a função de escorar o cavalete e transmitir vibrações ao restante do instrumento. É usualmente feita de pinho e posicionada sob o pé direito do cavalete.
} 
superior e o fundo ${ }^{5}$ dos instrumentos de corda são feitos com madeiras diferentes. 0 abeto é a madeira tradicionalmente empregada no tampo, por ser muito elástica, firme e resistente. Para o fundo (tampo inferior), é utilizado o ácero, que apresenta densidade e rigidez maiores que a do abeto. É importante salientar que os tampos dos violinos não são meras peças de madeira: elas precisam se comportar como "tábuas harmônicas", com modos normais de vibração cujas freqüências sigam um padrão aproximadamente harmônico. Os luthiers ${ }^{6}$ fazem um cuidadoso trabalho de desbaste nas madeiras dos tampos e testam seus modos de vibração batendo levemente os dedos em lugares determinados até alcançar o resultado pretendido ${ }^{7}$. Dispostos simetricamente nos dois lados do cavalete, existem os "efes", orifícios em forma de um "f" estilizado, que, além de conferir certo charme à estética do instrumento, têm funções acústicas bem definidas. (DONOSO, et al, 2010, p.23).

Em primeiro lugar, tornam o tampo mais flexível na área mais central, onde fica o cavalete, facilitando a transmissão da vibração da corda para o corpo do violino. Em segundo lugar conectam a caixa acústica, uma cavidade cheia de ar, com o exterior, o que também influencia o som emitido (DONOSO, et al, 2008, p.4).

As vibrações geradas na corda são transmitidas ao tampo superior através do cavalete e ao fundo através da alma. As vibrações dos tampos fazem com que o ar, dentro da caixa, também vibre. A freqüência da ressonância dessa cavidade chamada de "ressonância do ar" - entre 270 e $290 \mathrm{~Hz}$, reforça significativamente a sonoridade da nota da segunda corda do violino (ré, com freqüência de 293,66 Hz) (DONOSO, et al, 2010, p. 24).

O cavalete é uma peça crucial para o violino, porque faz o acoplamento entre as cordas e o corpo do instrumento. Fabricado com madeiras duras, o cavalete fica na parte mais flexível do corpo do instrumento, exatamente a mais favorável para transmitir a vibração da corda para a caixa acústica. É importante salientar que o cavalete atua também como filtro acústico, transmitindo melhor algumas freqüências e enfraquecendo outras. A disposição das cordas, que passam pelo cavalete, por ranhuras específicas para cada corda, impõe uma força considerável sobre a superfície do tampo. Essa força vertical atinge em torno de 90 newtons, 0 que equivale ao peso de um corpo com cerca de $9 \mathrm{~kg}$ sobre o delicado tampo. A

\footnotetext{
${ }^{5}$ Tampo inferior do violino.

${ }^{6}$ Artesãos que constroem instrumentos de cordas.

${ }^{7}$ A nota resultante desse tipo de procedimento é denominada Tap Note.
} 
forma arqueada deste ajuda a distribuir essa carga, evitando que ceda com o tempo (DONOSO, et al, 2010, p. 24).

A alma do violino é um pino cilíndrico de madeira de abeto posicionado (não colado) entre os dois tampos, logo abaixo do pé do cavalete no lado onde estão as cordas mais agudas. Pequenas alterações em sua posição ou forma alteram significativamente o timbre e a sonoridade do instrumento. Ela altera os modos de vibração de ambos os tampos e funciona como o ponto de apoio de uma alavanca, imprimindo um leve movimento de balanço ao cavalete (como uma gangorra), que se acopla aos modos de vibração dos tampos. (DONOSO, et al, 2010, p. 24).

Assim como nas caixas acústicas, onde os sons graves são produzidos por alto-falantes relativamente grandes, que deslocam grandes quantidades de ar, 0 movimento de grande amplitude dos tampos na região das cordas mais graves também desloca grandes quantidades de ar. No lado direito, onde se localizam as cordas mais agudas, a alma limita a amplitude desse movimento. O resultado é uma radiação sonora de maior intensidade para o instrumento em sua totalidade e, além disso, uma intensidade mais balanceada do som, já que a intensidade das cordas mais graves se torna comparável à da corda mais aguda. (DONOSO, et al, 2010, p.24).

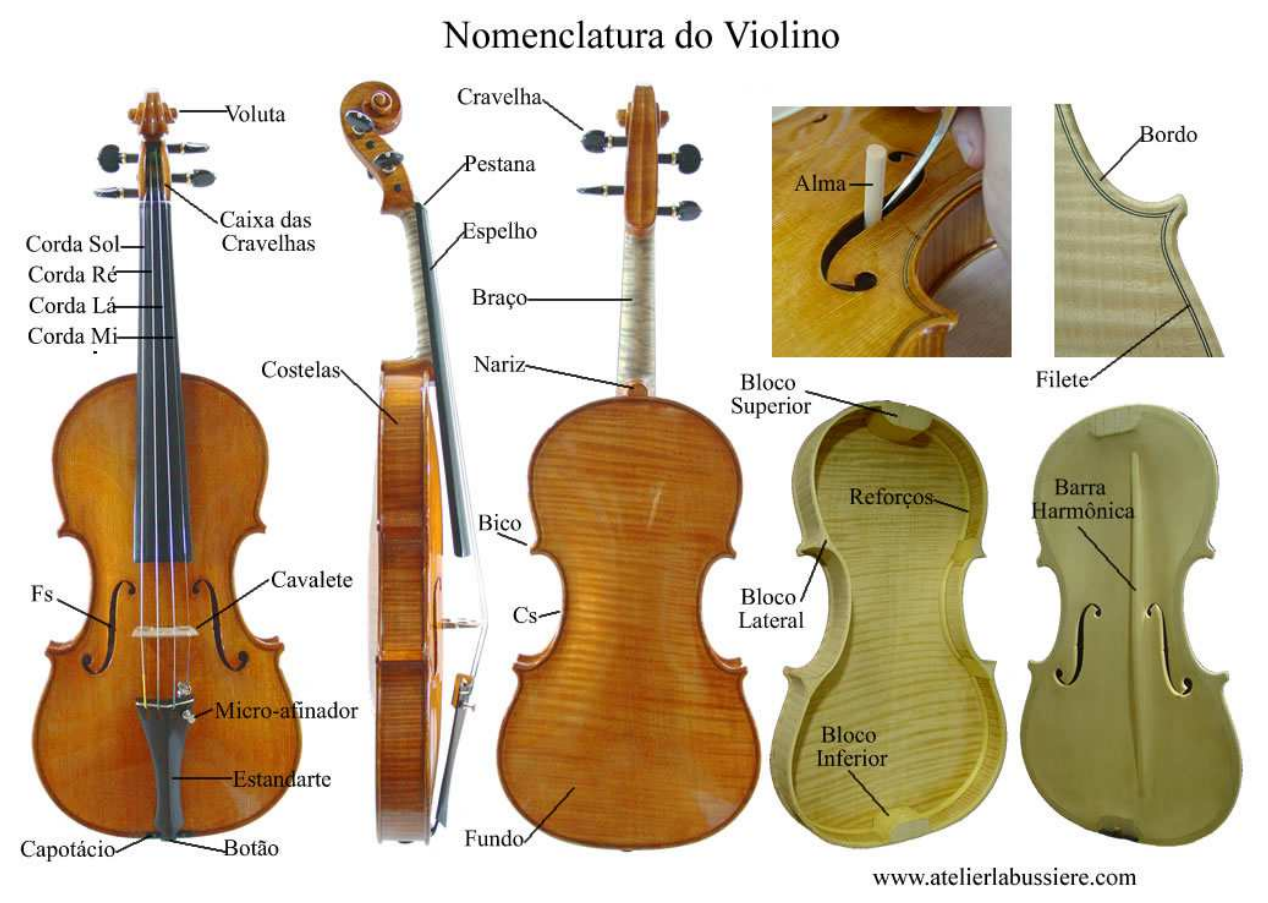

Figura 1 - Nomenclatura do violino. Fonte: Atelier La Bussiere, 2010. 
Embora precedido por um modelo de três cordas, o violino de quatro cordas já era conhecido em 1550. O instrumento era um amálgama da rabeca renascentista e da lira da braccio. (NELSON, 2003, p.16)

No século XVII os compositores passaram a explorar mais o instrumento, particularmente em óperas, sonatas e concertos. A escola italiana de luthiers, que despontou em meados do século XVI com Andrea Amati (ca.1505 - ca.1578) em Cremona e Gasparo da Salò (1540 - 1609) em Brescia, acompanhou a evolução dessas exigências através de constantes adaptações e aprimoramentos.

A fabricação de violinos teve seu auge entre 1650 e 1750, com os trabalhos do austríaco Jacob Stainer (1617-1683), do cremonense Nicolo Amati (1596-1864) e de seus alunos Giuseppe Guarnieri (1698-1744) e Antonio Stradivari (1644-1737). A produção desses dois últimos caracteriza-se por uma conformação mais plana do instrumento, modernização necessária para assegurar o potencial sonoro exigido pelas orquestras e maiores salas de concerto do século XIX.

No início do século XVIII, Antonio Stradivari, depois de muita experimentação, desenvolveu um violino com som mais poderoso para ajustar sua utilização nos concertos para violino. Stradivari criou seu novo modelo de violino achatando o tampo normalmente bem curvado, aprofundando os "c" para maior facilidade nas arcadas, aumentando os "f", melhorando o verniz e estabelecendo uma proporção entre a altura das laterais e o comprimento do corpo. Stradivari construiu cerca de 500 violinos e somente 18 violas. Entretanto, seus conceitos estruturais de construção dos instrumentos foram importantes para a construção de violas nas gerações seguintes.

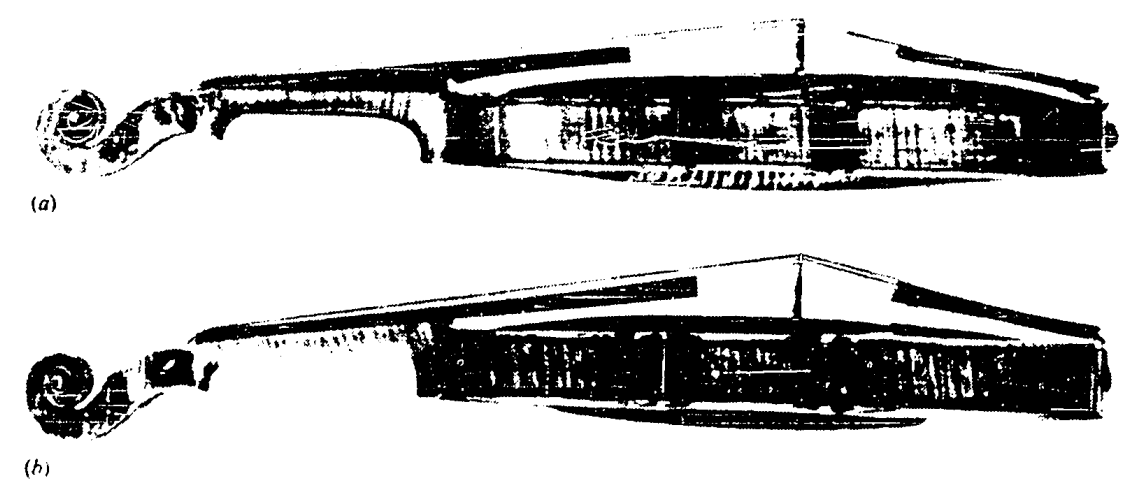

Figura 2 - Diferenças entre o violino barroco (Stainer, 1668) e o contemporâneo (J.B.Vuillaume, 1867).

Fonte: BOYDEN, 1980, p. 828. 
Apesar de mudanças de menor impacto, como a queixeira ${ }^{8}$, inventada por Spohr por volta de 1820, a forma e a técnica do violino já estavam padronizadas em 1800. Isso pode ser notado pelo fato de a maioria dos intérpretes atuais preferirem um violino italiano antigo juntamente com um arco do tipo Tourte ${ }^{9}$. No entanto, o instrumento é normalmente adaptado ao uso contemporâneo, com reforço interno, um cavalete mais elevado e o braço em ângulo mais agudo em relação ao corpo, para permitir maior tensão das cordas (Figura 2). Possui também um espelho mais longo, possibilitando alcançar notas mais agudas.

Não houve desenvolvimento significativo do violino desde o século XVIII, apesar das tentativas de aprimoramento das formas do corpo, dos materiais a partir dos quais o instrumento é manufaturado e de sua estrutura acústica. Há quase dois séculos existem os violinos produzidos em série, para uso educacional, não apenas nos grandes centros educacionais da Europa, mas atualmente também nos Estados Unidos e China.

O som do violino é obtido deslizando-se o arco sobre as cordas, produzindo vibrações que são transmitidas através do cavalete para o tampo harmônico, e da alma para o fundo.

Existe uma grande variedade de movimentos de arco, possibilitando ao executante a articulação dos sons em um extenso leque de gradações, do legato ao staccato. Além disso, são possíveis outros efeitos, como o pizzicato ${ }^{10}$, o tremolo $^{11}$, o col legno ${ }^{12}$, sul ponticello ${ }^{13}$ e sul tasto ${ }^{14}$.

Inclinando-se o arco num ângulo que encoste em duas cordas simultaneamente, produz-se acordes de duas notas. Lançando o arco através das cordas, é possível obter acordes de três a quatro notas, porém arpejados, devido ao ângulo da disposição das cordas. O executante pode deslizar a mão esquerda ao longo do braço, em diferentes posições ${ }^{15}$, fazendo uma seleção diferente das notas disponíveis, conforme a necessidade da música.

\footnotetext{
${ }^{8}$ Peça existente na viola e no violino, onde se apóia o queixo, e também auxilia a manter o instrumento na posição correta.

${ }^{9}$ Esse item será mais aprofundado no Capítulo III, que se encontra no decorrer deste estudo.

${ }^{10}$ Maneira de tocar as notas puxando as cordas com a ponta do dedo.

11 Maneira de tocar com o arco, muito rapidamente com movimentos pequenos em vaivém, produzindo um efeito trêmulo sobre as cordas.

12 Maneira de tocar utilizando a madeira do arco, ao invés das crinas, utilizando esta como uma pequena baqueta.

${ }^{13}$ Maneira de tocar rente ao cavalete, obtendo um som raspado.

${ }^{14}$ Maneira de tocar próximo ao espelho, produzindo sonoridade delicada.

${ }^{15}$ As posições no braço do violino são relativas à posição dos dedos.
} 
É possível produzir harmônicos encostando-se levemente o dedo numa corda, ao invés de pressioná-la contra o espelho. O resultado é um som agudo e delicado, como o de uma flauta. Os primeiros harmônicos naturais de cada corda são facilmente obtidos. Também é possível produzir harmônicos artificiais. ${ }^{16}$

\subsection{A Viola}

A viola é o instrumento de tessitura intermediária da família dos violinos. Sua posição pode ser comparada com a voz contralto da formação normal de um coro Soprano, Alto, Tenor e Baixo (SATB), estando o contralto logo abaixo da tessitura do soprano. Na realidade, a tradução da palavra viola para o francês é alto.

Assim como o violino, possui quatro cordas, sendo que a mais grave soa uma quinta abaixo que a mais grave do violino. É tocada com o arco e apoiada no ombro do instrumentista, do mesmo modo que o violino. Em alemão, a palavra para viola é bratsche, tendo como origem a palavra em italiano braccio, que significa braço em português. A etimologia da palavra viola, ou viola da braccio, leva alguns historiadores a acreditar que a família do violino surgiu na Itália durante o início do século XVI. A viola possivelmente surgiu pouco antes do violino - a palavra violino é diminutivo de viola.

A viola pode, portanto, ser considerada antepassada do violino, tendo sido resultado do aperfeiçoamento da vielle e ter dado origem a uma família inteira de instrumentos de características iguais e tamanhos diferentes. $O$ arco também possui tamanho e peso diferente do violino, porém, para se tocar o instrumento, adota-se técnica praticamente idêntica.

Pelo fato de ter a mesma forma do violino, ou seja, ter o mesmo tipo de construção e serem utilizados os mesmos materiais que um violino, mas em tamanho maior, a viola possui as mesmas possibilidades técnicas que este, com diferenças sutis em sua execução.

Embora estivesse definitivamente estabelecida como membro da recémcriada família dos violinos, em 1535 não era chamada "viola", uma vez que o termo

\footnotetext{
${ }^{16}$ Quando o executante prende a corda com um dedo e posiciona outro dedo num ponto equivalente a uma nota uma quarta ou quinta acima daquela que está presa, obtendo um som duas oitavas acima da nota cujo dedo está preso.
} 
possuía uma gama de aplicações, referindo-se tanto a instrumentos específicos quanto, genericamente, a qualquer instrumento de cordas tangidas com arco ou pinçadas. No século XVIII, a viola era designada usualmente pela expressão viola da braccio. A partir do século XVII, a viola era o instrumento central indispensável nos conjuntos de cordas; havia geralmente duas ou três, cumprindo tanto a função de contralto como de tenor e construídas em tamanhos proporcionais. Nos grupos de cordas francesas a cinco partes, as três partes centrais eram executadas por violas.

No século XVIII, houve uma padronização dos naipes de cordas, tanto nas orquestras como nos grupos de câmara, principalmente com o surgimento da formação do quarteto de cordas, cujo reconhecimento se deve a Joseph Haydn (1732-1809), depois imortalizado por Wolfgang Amadeus Mozart (1756-1791). Outros compositores, como Beethoven (1770-1827), Schubert (1797-1828), Brahms (1833-1897), Mendelssohn (1809-1847), Schumann (1810-1856), Dvorák (18411904), Smetana (1824-1884) e Bartók (1881-1945), contribuíram, no decorrer da história, para o desenvolvimento do gênero.

No movimento das variações do Quarteto op.20 n.4 de Haydn (1772), a viola divide a primeira variação com o segundo violino, e no movimento das variações do Quarteto op.76 n.3, "Imperador" (1797), a viola tem um tema solo. No Quarteto K.421 de Mozart (1783) há uma variação lírica no último movimento efetuada pela viola, e no Quarteto op.59 n.3 de Beethoven, o violista tem de saltar da primeira à quinta posição na corda mais grave (dó) em resposta a passagens similares do violino e do violoncelo.

Schubert pede cordas duplas sucessivas em terças e sextas, embora na primeira posição, em seu Quarteto op.161. Brahms deixa a viola sem surdina no movimento Agitato de seu Quarteto op.67, expondo material temático, sendo que os outros três instrumentos utilizam a surdina. Dvorák e Smetana não somente escreveram partes de viola proeminentes, como ambos os compositores colocaram o tema de abertura do primeiro movimento na viola.

Compositores sinfônicos após 1750 também começaram a explorar a sonoridade única e o timbre da viola.

Já no século XIX houve uma exploração considerável das possibilidades da viola na música orquestral, que continuou durante 0 século $X X$ com 0 reconhecimento da viola como instrumento solista. 
Para enfatizar as qualidades da viola na voz mais aguda, por exemplo, Brahms eliminou todos os violinos no primeiro movimento do Réquiem Alemão, e de toda a Serenata op.16, tornando as violas a voz predominante nas cordas. Richard Strauss (1864-1949) e Berlioz (1803-1869) escreveram longas partes solo obligato para a viola, destacando-a na orquestra, nas obras Dom Quixote e Haroldo na Itália, respectivamente.

O papel da viola, em outros tempos limitado a desempenhar as modestas, embora necessárias, funções de preencher a harmonia no quarteto e na orquestra, adquiriu pouco a pouco, na segunda metade do século XIX, uma função bem distinta, alcançando um valor expressivo e autônomo reservado até então somente aos violinos. No fim do século XIX o instrumento deu passos gigantescos com 0 desenvolvimento da técnica por Lionel Tertis ${ }^{17}$ e as obras virtuosísticas escritas para viola solista por compositores como Bartók, Ligeti, Hindemith (1895-1963) e Bloch (1880-1959).

\footnotetext{
${ }^{17}$ Violista inglês nascido em 1876 foi o primeiro instrumentista a valorizar a viola como instrumento solista e a formar uma escola técnica para o instrumento.
} 


\section{Capítulo 2 - O Arco: História e Evolução}

Em sua origem, o arco dos instrumentos de cordas em tudo se assemelhava ao seu homônimo, peça de arma utilizada para arremessar flechas: vareta curvada em forma de meia-lua, a cujas pontas se atava algum tipo de corda ou cerda retorcida, mais tarde substituída por crina animal. Era com artefato similar que o músico da antiguidade efetuava o atrito com a corda necessário para a produção do som.

A utilização do arco para a obtenção de som de um instrumento de cordas tem sua origem quase seis séculos antes da evolução da família dos violinos. Violinistas e violistas adotaram, inicialmente, os tipos de arco utilizados por executantes de outros instrumentos de cordas, como a rabeca e a viola da gamba. Não havia padrão de peso, comprimento, forma e tipo de madeira para esses arcos, mas eles possuíam algumas características em comum.

Muitos modelos do início do século XVII eram curtos (cerca de $36 \mathrm{~cm}$ ), mas há evidências de que chegaram a ter $61 \mathrm{~cm}$ até o fim do século (STOWELL, 2001, p. 38). Normalmente eram convexos e os fios da crina eram esticados com uma tensão fixa entre a ponta (em alguns casos, não havia uma ponta definida, a crina simplesmente encontrava a madeira em um ponto qualquer) e o talão na parte inferior da madeira.

Foram pesquisados alguns exemplos de arco do século XVII, mas as evidências iconográficas sugerem que a forma dos arcos estava diretamente ligada a gostos e necessidades musicais. Arcos pequenos, leves e praticamente retos eram ideais para os músicos de dança e especialmente populares na França, enquanto o aumento do emprego da forma sonata e do concerto na Itália fazia necessária a utilização de arcos mais compridos, retos (embora às vezes levemente convexos), modelos capazes de produzirem estilo mais cantabile com maior abrangência de dinâmicas. Arcos convexos, com comprimento intermediário eram preferidos pelos instrumentistas alemães, porque facilitavam a execução do estilo polifônico alemão.

A padronização gradual dos estilos durante o século XVIII e a demanda pelo aumento de volume de som e extensão das dinâmicas, além do desenvolvimento na construção dos instrumentos, levaram à construção de arcos mais estreitos e 
longos. O estreitamento da madeira exigiu que houvesse também modificações no peso e na curvatura da chamada "cabeça de cisne"18, com o objetivo de permitir uma separação suficiente entre a crina e a madeira.

No século XVIII, os fabricantes começaram a antecipar a utilização do ângulo côncavo dos arcos modernos e outras modificações foram necessárias para que houvesse uma otimização da separação entre crina e madeira no meio do arco.

Das grandes curvaturas côncavas, passou por uma silhueta quase retilínea, até a incorporação da forma atual, convexa. Paralelamente à evolução dos instrumentos de cordas, o arco, peça fundamental à sua execução, foi objeto de transformação equivalente (Vide figuras 3 e 4).

Giuseppe Tartini (1692-1770) ${ }^{19}$ foi o principal idealizador do parafuso de ajuste do talão, que veio possibilitar o controle da tensão da crina - mecanismo introduzido por Nicolas Tourte $(1700-1764)^{20}$, pai de François ${ }^{21}$. Anteriormente à invenção do parafuso, era com o dedo mínimo da mão direita que as cerdas dos arcos dos violones, por exemplo, eram puxadas para baixo, aumentando ou diminuindo-lhes a tensão. Por essa razão surgiu a maneira peculiar de empunhar o arco, por baixo do talão, entre os instrumentos da família da viola da gamba, cuja adaptação para contrabaixo ficou conhecida como Bolonhesa ou à Dragonetti.

Essa modalidade foi adotada posteriormente pelos alemães, razão pela qual, ironicamente, recebeu a denominação arco tedesco ${ }^{22}$ até mesmo na Itália, seu país de origem.

Foi na França, entretanto, que no final do século XVIII François Tourte ${ }^{23}$ fez uma modificação que revolucionou a técnica de todos os instrumentos de cordas. Por volta de 1770 ele vergou a madeira do arco em sentido contrário, convexamente, com a barriga da curva em direção à crina. A vareta foi, assim, dotada de maior tensão e flexibilidade.

Foi também Tourte, originalmente um modesto relojoeiro, o responsável por experiências que levaram à escolha da madeira ideal, hoje universalmente utilizada - o pau-brasil, também conhecida como pau-rosado ou Pernambuco. Tourte

\footnotetext{
${ }^{18}$ Ponta do arco.

${ }^{19}$ Violinista, compositor e fundador de uma escola de violino (1692-1770).

${ }^{20}$ Luthier francês.

${ }^{21}$ François Tourte (1747-1835) foi um luthier francês que efetuou modificações significativas na forma do arco no período clássico, cuja forma é utilizada até hoje.

${ }^{22}$ Alemão, em italiano.

${ }^{23}$ Fabricante de arcos. 1747-1835.
} 
também fixou as dimensões ideais para o arco do violino, cuja medida padrão é 75 $\mathrm{cm}, 60$ gramas e 150 fios de crina, e do arco de viola, $74 \mathrm{~cm}, 70$ gramas e 175 fios de crina.

Quanto à construção, o arco moderno pode ser subdividido em dois grupos principais. O primeiro seria o modelo do violino, padrão também empregado pela viola e o violoncelo, assim como uma das modalidades do arco do contrabaixo, a denominada francesa. O segundo seria o modelo da outra modalidade do arco do contrabaixo, a denominada alemã.

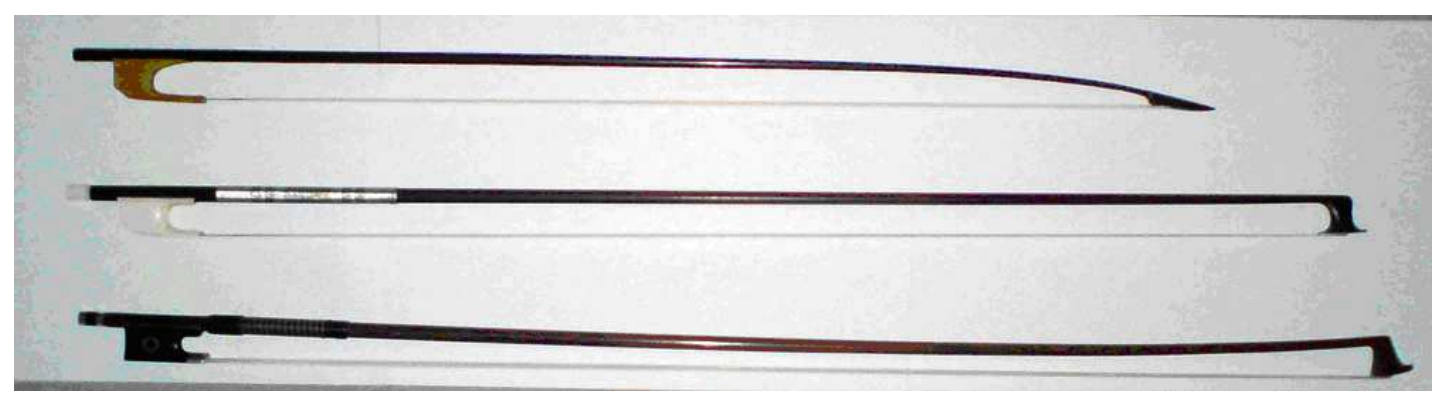

Figura 3 - (a) arco barroco; (b) arco clássico e (c) arco moderno, respectivamente. Fonte: NELSON, 2003, p. 126. 


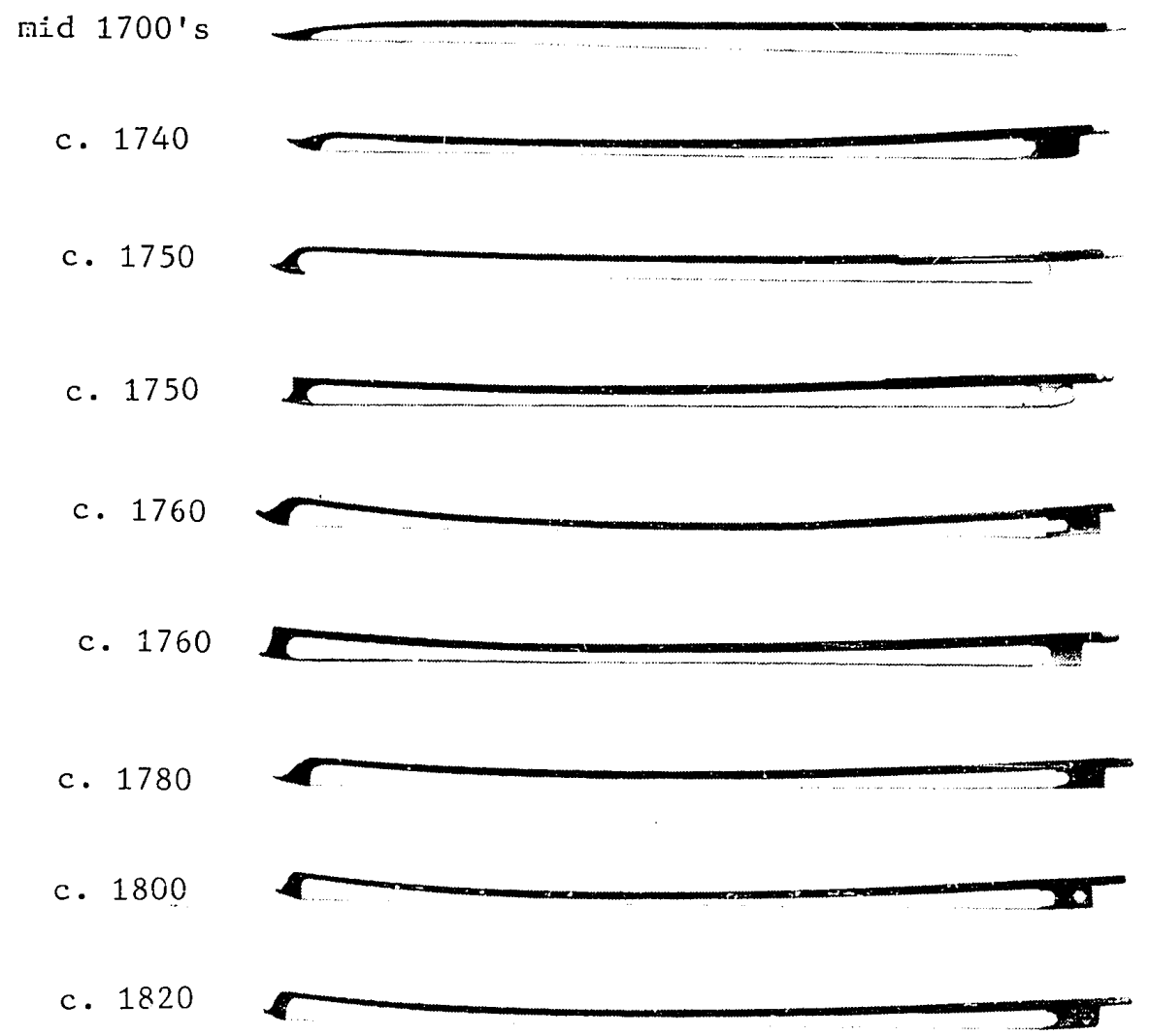

Figura 4 - Nove estágios no desenvolvimento do arco do violino (1756-1820). Fonte: NELSON, 2003, p. 128. 


\title{
Capítulo 3 - Diferenças entre Violino e Viola
}

\author{
O violino e a viola apresentam diferenças significativas, que influenciam a \\ afinação, a sonoridade e outros aspectos importantes. Segundo Boyden (1980, p. \\ 809):
}

\begin{abstract}
Diferenças na técnica estão relacionadas com o tamanho maior da viola. Para começar, seu peso e tamanho exigem com que seja segurada geralmente com a voluta um pouco mais baixa que a do violino; a posição tipicamente horizontal do violino seria muito cansativa. $O$ dedilhado da viola, apesar de similar ao do violino, exige alongamentos maiores e, às vezes, maior pressão da mão esquerda; o da viola é, portanto, de alguma forma, mais difícil de lidar. O vibrato é mais lento e menos intenso na viola que no violino. Além disso, as arcadas da viola são a princípio as mesmas que as do violino, exceto que o violista utiliza mais pressão nas cordas mais grossas para fazê-las soar apropriadamente, e o arco é geralmente mais grosso, mais pesado e um pouco mais curto. ${ }^{24}$
\end{abstract}

Já Riley (1980, p. 185) sugere diferenças técnicas mais detalhadas:

\begin{abstract}
Algumas diferenças são sutis, entretanto são cruciais para produzir a sonoridade característica da viola e para a performance com uma técnica mais simples. Violas grandes freqüentemente exigem a utilização da meia posição, extensões, substituições do terceiro dedo pelo quarto para acomodar mãos pequenas em grandes extensões, e a substituição do terceiro dedo pelo segundo em passagens arpejadas para prevenir um alongamento difícil que poderia ocorrer de outra maneira entre o terceiro e quarto dedos. Para obter resposta e ressonância máxima em muitas violas, é necessário tocar com toda a crina do arco na corda ao invés do ângulo característico do violino. ${ }^{25}$
\end{abstract}

\footnotetext{
24 "Differences in technique are related to the viola's large size. For one thing, its weight and size require that it be held with its scroll generally a bit lower than it is on the violin; the violin's typically horizontal position would be too tiring. Viola fingering, while similar to the violin's, demands grater stretches and sometimes greater left-hand pressure; the viola is thus somewhat more difficult to handle. The vibrato is generally somewhat slower and less intense on the viola than on the violin. Again, viola bowing is in principal the same as the violin's except that the violist uses somewhat heavier pressure on his thicker strings to make them speak properly, and the bow itself is generally a bit thicker, heavier, and slightly shorter"(BOYDEN, 1980. p. 809).

25 "Some of these differences are subtle, but nevertheless are crucial to producing the characteristic viola sound and to performing with a facile technique. Large violas frequently require the use of half-position, extensions, substitutions of the 4th finger for the 3rd to accomodate small hands in excessive reaches, and substitutions of the 2nd finger for the 3rd in arpeggiated passages to obviate an awkward stretch that would otherwise occur between the $3 r d$ and the 4 th fingers. To obtain maximun ressonance and response on many violas, it is necessary to bow with the hair flat on the string rather than at an angle characteristic of the violin" (RILEY, 1980, p. 185).
} 


\subsection{Tamanho dos Instrumentos}

A viola é afinada uma quinta abaixo que o violino, sua corda mais grave $\left(\text { dó }_{2}\right)^{26}$ tem uma freqüência de $130 \mathrm{~Hz}$, significando 1,5 vez maior que a freqüência da corda mais grave do violino ( sol $_{2}$ ), com freqüência de $196 \mathrm{~Hz}$ (DAVIS, 2010). Se as características acústicas da viola fossem as mesmas do violino, a viola deveria ter proporcionalmente, em teoria, uma caixa 1,5 vez maior que a do violino.

O tamanho aproximado da caixa de um violino padrão é $35,5 \mathrm{~cm}$. Conseqüentemente, a escala proporcional para o tamanho da caixa da viola deveria ser 53,8cm. Entretanto, esse tamanho de viola é impraticável para os instrumentistas, pois o instrumento seria muito grande e pesado, e o braço do instrumentista não alcançaria a região grave de cada corda a ser dedilhada.

Os luthiers passaram a construir violas em uma dimensão menor, entre 38 e $43 \mathrm{~cm}$, ou seja, 1,07 a 1,2 vez maior que o violino. O tamanho proporcionalmente menor da viola, relativo à propagação do som na freqüência mais grave possui diversas implicações para as propriedades acústicas do instrumento.

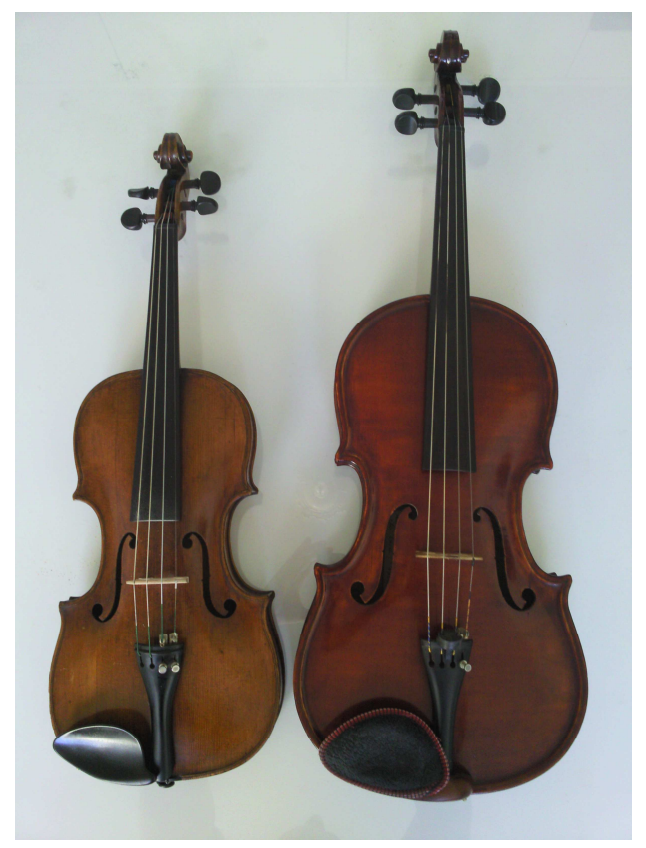

Figura 5 - violino (à esquerda) e viola (à direita)

Fonte: Imagens captadas pela autora.

\footnotetext{
${ }^{26} \mathrm{O}$ dó central é o dó 3 .
} 
Para entender essas implicações há necessidade de examinar primeiramente, a maneira que os instrumentos vibram.

\subsection{Ressonâncias}

Um violino é constituído por um conjunto de quatro cordas esticadas sobre uma caixa acústica. As quatro cordas estão afinadas em intervalos de quintas justas - o que significa sete semitons - e suas notas musicais e respectivas freqüências são: sol $_{2}$ (196 hertz, ou ciclos por segundo), ré $3(293,66 \mathrm{~Hz})$, lá $3(440 \mathrm{~Hz})^{27}$ e mi

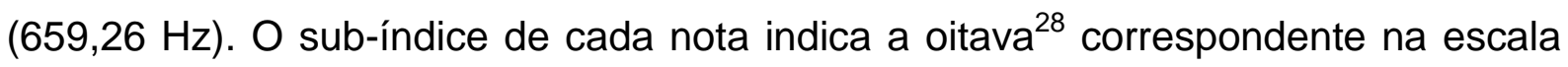
temperada ${ }^{29}$.

Assim, o lá indica a nota lá da quarta oitava, com freqüência de $440 \mathrm{~Hz}$. A corda $\mathrm{mi}_{4}$, que é a mais fina de todas, é uma corda simples enquanto as cordas lá, ré $_{3}$ e sol $_{2}$ são compostas, com uma corda central e um bordão em forma de fita enrolado por cima.

Cada uma das cordas da viola é afinada uma quinta abaixo das respectivas cordas do violino, ou seja: dó 2 : 130.8 Hz; sol 2 : 196 Hz; rés: $293.7 \mathrm{~Hz}$ e lá 3 : $440 \mathrm{~Hz}$. Pelo fato de num intervalo de quinta as freqüências das notas estão numa razão $3: 2^{30}$, poderíamos pensar que, para fabricar uma viola bastaria então aumentar as dimensões de um violino num fator 1.5 .

Como já foi mencionado, a caixa do violino tem $35 \mathrm{~cm}$ de comprimento ${ }^{31}$. A viola "ideal" teria então cerca de $53 \mathrm{~cm}$. Porém esta viola seria um instrumento demasiado grande para ser apoiado sobre o ombro. O tamanho de uma viola moderna é de 40 a $42 \mathrm{~cm}$, ou seja, cerca de 17\% maior que um violino, mas suas ressonâncias principais são de $20 \%$ a $40 \%$ mais baixas que as do violino (Tabela 1 ).

\footnotetext{
${ }^{27}$ Frequiência padrão de vibrações da nota lá para afinação, embora hoje em dia seja utilizada a afinação em 441 ou $442 \mathrm{~Hz}$.

${ }^{28}$ Denomina-se 'oitava' o intervalo em que a freqüência de um som dobra. A nota lá $x_{3}$ tem freqüência de $440 \mathrm{~Hz}$ e o lá 4 de $880 \mathrm{~Hz}$, por exemplo.

${ }^{29}$ Escala temperada é a escala musical com subdivisões (12 semitons em uma oitava) sempre iguais, utilizada na música atual.

30 Três dividido por dois.

${ }^{31}$ Medidas do instrumento inteiro, considerando corpo, braço e voluta. As medidas padrão do instrumento se referem apenas ao tamanho do corpo.
} 
É importante salientar que esse aumento na dimensão da viola cobre apenas uma parte da diminuição da freqüência da cavidade, sendo o restante conseguido utilizando-se cordas mais grossas (DONOSO, et al, 2008, p. 8).

Tabela 1 - Violino versus Viola*

\begin{tabular}{ccccc}
\hline & Afinação & Comprimento $(\mathrm{cm})$ & Fator da escala & Frequencia de ressonância \\
\hline Violino & Sol Ré Lá Mi & 35 & 1.00 & $270-280 \mathrm{~Hz}$ \\
Viola & Dó Sol Ré Lá & $40-42$ & 1.17 & $\sim 220 \mathrm{~Hz}$
\end{tabular}

Fonte: DONOSO, et al, 2008.

* Afinação das quatro cordas do violino e da viola; comprimento típico da caixa dos instrumentos e o fator de escala entre eles, considerando o violino como dimensão unitária, e freqüência de ressonância da cavidade do instrumento.

Apesar de pertencer à mesma família de instrumentos, a viola não pode ser considerada apenas um "violino grande", por ser um instrumento com característica sonora própria.

A característica do violino é atribuída à existência de um timbre ${ }^{32}$ específico em cada uma de suas cordas. A mais aguda $\left(\mathrm{mi}_{4}\right)$ é brilhante e incisiva; a segunda (lás) é doce e delicada; a terceira (ré $_{3}$ ) tem uma sonoridade profunda, ressonante e melodiosa; e a quarta $\left(\mathrm{sol}_{2}\right)$ é grave e imponente.

O som emitido por uma corda que vibra é determinado pela freqüência fundamental $^{33}$ e seus parciais, ou harmônicos ${ }^{34}$. A vibração da corda friccionada por um arco é diferente da vibração da corda tangida, como a de um violão, por exemplo. Quando uma corda é "beliscada"35, o som não é contínuo, portanto, os parciais gerados decaem rapidamente e são inarmônicos ${ }^{36}$. Se a corda é friccionada por um arco, porém, a oscilação é mantida e a onda sonora resultante assume uma forma denominada "dente de serra" ${ }^{37}$, composta pela repetição e superposição de harmônicos (DONOSO, et al, 2008, p. 15).

\footnotetext{
${ }^{32}$ Característica sonora.

${ }^{33}$ Fundamental é a mais baixa e mais forte frequência componente da série harmônica de um som. Tecnicamente a fundamental corresponde ao primeiro harmônico. A fundamental é responsável pela percepção da altura de uma nota, enquanto que os demais harmônicos participam da composição da forma de onda do som.

${ }^{34}$ Vibrações com frequiências múltiplas de uma freqüência fundamental.

35 Tocada com a ponta dos dedos.

${ }^{36}$ Em que não há harmonia.

${ }^{37}$ Uma onda dente de serra é uma espécie de forma de onda não-senoidal básica. Ela recebeu o nome dente de serra baseado em sua semelhança com a lâmina de uma serra.
} 
Assim, o espectro sonoro ${ }^{38}$ do violino tem a freqüência da nota executada o que compreende a freqüência fundamental e também um grande número de harmônicos de amplitudes decrescentes, todos múltiplos inteiros da freqüência daquela nota.

Espectros sonoros ricos em harmônicos melhoram a qualidade do som de uma nota tocada por um instrumento, que é determinada pelo número de harmônicos presentes e suas amplitudes. Embora a amplitude da vibração das cordas do violino seja considerável - cerca de $1 \mathrm{~mm}$, o som liberado para o ar é muito fraco. As cordas são muito finas e, ao vibrar, deslocam pequena quantidade de ar. Portanto, é necessário transferir essa vibração para uma superfície bem grande, de forma que esta, ao vibrar, desloque um volume apreciável de ar e aumente a intensidade do som.

No violino, a peça que transfere as vibrações das cordas para a caixa acústica é o cavalete, e os grandes tampos dessa caixa são bastante eficientes para movimentar o ar à sua volta e aumentar a radiação do som, atuando da mesma forma que o cone de um alto-falante. Como já mencionado, as cordas se estendem desde as cravelhas até quase a extremidade oposta do violino. É importante salientar que o único ponto de contato entre as cordas e o tampo superior do instrumento é o cavalete. Essa disposição das cordas no violino resulta numa força considerável sobre a superfície do tampo superior (DONOSO, et al, 2008, p. 15). (Figura 6).

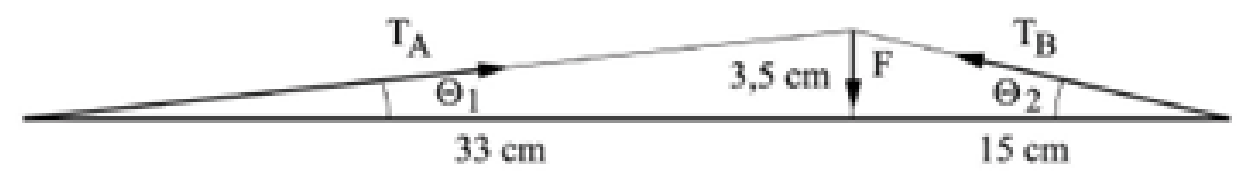

Figura 6 - Diagrama de forças - utilizado para calcular a resultante vertical sobre o tampo superior do violino. A figura indica as distâncias desde o cavalete até as extremidades do instrumento (seguindo o comprimento das cordas) e a altura do cavalete.

Fonte: DONOSO, 2008, p. 6.

O instrumento possui também uma ripa de madeira, a barra harmônica, colada por baixo do tampo superior logo abaixo da perna direita do cavalete (no lado

\footnotetext{
${ }^{38}$ Conjunto de todos as ondas que compõem os sons audíveis e não audíveis pelo ser humano.
} 
correspondente às cordas mais graves) e orientada no sentido das cordas. Essa barra harmônica tem uma função acústica de transmitir as vibrações a todo o corpo do violino, fazendo com que uma grande área do tampo oscile em fase, ou seja, no mesmo sentido e velocidade, o que é especialmente importante para os sons graves que possuem comprimentos de onda grandes. Tem também uma função estrutural, fornecendo suporte mecânico à estrutura do instrumento, para ajudar o tampo a suportar parte da força exercida pelas cordas através do cavalete (DONOSO et al, 2008, p. 6).

As pesquisas desenvolvidas por Felix Savart ${ }^{39}$ no século XIX mostraram que a função da alma não se limita a transmitir as vibrações do tampo superior para o inferior do instrumento. Ela também altera os modos vibracionais de ambos os tampos ao impor um ponto nodal ${ }^{40}$ praticamente estacionário nos pontos de contato entre eles. A alma também ajuda a suportar a força exercida pelas cordas sobre 0 tampo superior, distribuindo parte do esforço ao tampo inferior (DONOSO et al, 2008, p. 6).

O violino tem suas propriedades acústicas fortemente influenciadas pela alma e pela barra harmônica. A alma tem uma importância primordial no instrumento sendo que pequenas mudanças em sua posição, na sua forma ou na qualidade da madeira podem alterar significativamente o timbre e a sonoridade do instrumento. É importante salientar que a alma não está colada nos tampos, ela apenas se mantêm em sua posição devido à força exercida pelas cordas sobre o cavalete e o tampo superior. O seu posicionamento, portanto, é uma das tarefas mais delicadas do trabalho do luthier.

O corpo do violino ressoa quando suas cordas vibram. Diferentemente de um alto-falante, cujo objetivo não é ressoar em qualquer freqüência, mas vibrar exatamente em todas as formas complexas de ondas sonoras, o violino produz som somente porque seu cavalete faz com que suas cordas ressoem. É essencial que o corpo do violino ressoe de diferentes maneiras e que a forma de sua ressonância se modifique continuamente com freqüência através de toda a gama de freqüências que pode produzir.

\footnotetext{
${ }^{39}$ Médico e físico francês (1791-1841). Estudou a acústica do ar, da voz humana, do canto das aves, de sólidos em vibração e das ondas sonoras em líquidos em movimento. Inventou o Ressonador de Savart para medição de vibrações sonoras. Produziu a primeira explicação para o funcionamento do violino, fazendo uso do seu ressonador. Em sua honra foi criada na física, uma unidade de intervalo logarítmico de freqüência com a denominação de Savart de frequiência. Uma oitava é aproximadamente 301 Savart.

${ }^{40}$ Ponto de congruência de uma onda vibratória na qual a amplitude é zero.
} 
Antes de considerar o comportamento do instrumento inteiro, existe um processo físico mais importante para controlar a transferência da vibração da corda para o corpo. Onde há uma ressonância mais forte, o corpo vibra mais e absorve mais energia da corda. Onde há menos ressonância, o corpo vibra menos e absorve menos energia da corda. A quantidade de energia que passa através do cavalete da corda para o corpo em qualquer freqüência depende da aptidão do corpo do instrumento para vibrar nas ressonâncias nessa freqüência. O corpo determina quanta energia em cada freqüência serão tiradas do cavalete e o cavalete absorve essa energia em cada freqüência da corda. Entretanto, a madeira do corpo normalmente absorve energia também de cada freqüência harmônica na proporção do tamanho do harmônico na vibração da corda. Se isso não acontecesse, o corpo absorveria a maioria da energia de uma corda tocada levemente com arco, mas a menor proporção disso em uma corda tocada fortemente com arco na mesma afinação dificultaria o controle da dinâmica.

Como se pode observar, a madeira precisa absorver quase toda a energia em cada ciclo de vibração, além da pequena quantidade transformada em som. $O$ som produzido em qualquer arcada contém o harmônico de cada corda, seu tamanho ajustado pela ressonância do corpo em cada freqüência.

Se o cavalete absorve diferentes quantidades de energia de diferentes componentes das freqüências da vibração da corda, o que acontece com a vibração da corda em si? O som é diferente quando seus componentes são modificados. Primeiro, cada vez que o ciclo de vibrações da corda inicia, o arco restabelece a forma de sua vibração. De outra maneira, a vibração da corda modificaria progressivamente durante a parte sustentada da nota e o som seria modificado.

A madeira do corpo do instrumento vibra em intensidades diferentes quando diferentes alturas de som são tocadas. Em certas alturas de som, a corda vibra na mesma freqüência em que a madeira vibra naturalmente e o corpo do instrumento responde oscilando em amplitude alta. A ressonância também ocorre na cavidade entre os tampos do instrumento.

As alturas de som ou freqüências que geram essas respostas na madeira são chamadas ressonâncias de madeira. As que afetam a cavidade do ar são chamadas ressonâncias de ar. A ressonância principal da madeira e a ressonância principal do ar correspondem às freqüências mais baixas da madeira e da coluna de ar. 
A relação entre a ressonância principal da madeira e a ressonância principal do ar é extremamente importante para a sonoridade e qualidade do instrumento. Em um bom violino, a ressonância principal do ar e a ressonância principal da madeira têm um espaço de aproximadamente uma quinta justa, isoladamente com a ressonância principal do ar, ocorrendo na nota dó ${ }_{3}$ ou dó\# ${ }_{3}$ na corda sol, e a ressonância principal da madeira, que ocorre na nota sol $_{3}$ ou sol\# 3 na corda ré.

Essas ressonâncias servem para reforçar o som do violino porque estão situadas muito perto das duas cordas soltas centrais (lá e ré). Isso contribui para o som brilhante, uniforme e com projeção nos diversos registros em bons violinos. Em violinos de qualidade inferior, a ressonância principal do ar e a ressonância principal da madeira não ocorrem perto das duas cordas soltas centrais e, conseqüentemente, o som produzido é mais fraco.

Se o tamanho da viola fosse proporcional ao do violino em escala, veríamos a ressonância principal do ar e a ressonância principal da madeira com os mesmos padrões. Entretanto, a viola é proporcionalmente menor (Tabela 2), o que significa que o comprimento da madeira e o volume da cavidade de ar são menores em comparação ao comprimento da onda da nota mais grave do instrumento (RIDGEN, 1985, p. 162).

Tabela 2 - Comparação dos comprimentos e volumes da caixa de ressonância do violino e da viola

\begin{tabular}{lcc}
\hline $\begin{array}{l}\text { Comprimento do corpo do instrumento (em centímetros) } \\
\text { Comprimento necessário da caixa para fazer com que a }\end{array}$ & 35,5 & Viola \\
$\begin{array}{l}\text { ressonância da madeira corresponda ao violino (em } \\
\text { centímetros) }\end{array}$ & 35,5 & 53,3 \\
$\begin{array}{l}\text { Relação necessária para fazer a ressonância de ar } \\
\text { corresponder com o violino }\end{array}$ & 1 & 1,5 \\
\hline
\end{tabular}

Fonte: BEAMENT, 1977, p. 86.

As proporções alteradas têm o efeito de troca da ressonância principal, que chega a quase uma terça acima. A ressonância principal da madeira é também modificada para freqüências mais altas e, consequentemente, a ressonância principal de ar e a ressonância principal de madeira estão agora perto das duas cordas soltas centrais - lá e ré 3 no violino e ré e sol $_{2}$ na viola. 
A troca dessas ressonâncias resulta em dois efeitos importantes. Primeiro, contribui para que o timbre da viola nos registros mais agudos seja anasalado. Segundo, a intensidade dos harmônicos agudos na viola é menor que os do violino, portanto a viola não possui um som tão brilhante quanto o violino.

Existe ainda um outro pico de ressonância, conhecido como pico primordial da madeira. Quando a ressonância principal da madeira está localizada perto da corda solta lá $3(440 \mathrm{~Hz})$ no violino, o pico primordial da madeira está localizado perto da corda solta sol $_{2}(220 \mathrm{~Hz})$, que tem o efeito de reforçar as notas mais graves na corda sol.

$\mathrm{Na}$ viola, o pico primordial da madeira, como a ressonância principal da madeira, está localizado significantemente acima, mais uma vez contribuindo para o som mais nasal característico do instrumento. Poder-se-ia também pensar que isso enfraqueceria os registros mais graves da viola, contudo o registro mais grave da viola é frequentemente descrito como "de sonoridade clara, bonita, ressonante e poderosa, procurada ansiosamente tanto pelos construtores quanto pelos instrumentistas". 41

Podemos aplicar as teorias sobre o controle do som produzido por um instrumento de arco em uma série de testes simples. Iniciando com um violino normal, com cavalete de viola, removendo a corda mi e movendo as outras três cordas, sendo a corda lá posicionada no lugar da corda mi, a corda ré posicionada no lugar da corda lá e a corda sol posicionada no lugar da corda ré e adicionando uma corda dó, ficando assim com as cordas de uma viola.

Se tocado com arco como uma viola, o som do instrumento terá as características de uma viola. A proporção do cavalete equilibra os harmônicos de todas as três cordas do violino próximas às freqüências mais agudas. A corda lá, por exemplo, agora tem um som mais rico que a corda lá na posição do violino, e isso é muito característico da corda lá da viola.

Em seguida, mesmo supondo-se que uma viola pequena seja em torno de 16 por cento maior que o violino, não quer dizer que os fatores significantes na produção do som sejam modificados em apenas 16 por cento.

O cavalete é maior em cada uma de suas três dimensões - um cavalete normal de viola é mais de 50 por cento mais pesado que um cavalete de violino, e

\footnotetext{
${ }^{41}$ Boyden, D. "Viola". Disponível em: http://oxfordmusiconline.com/subscriber/article/grove/music/29438,
} acesso em 10de novembro de 2010. 
sua firmeza aumenta muito mais que 16 por cento para os 16 por cento aumentados em cada dimensão. Se um cavalete de viola do tamanho de um de violino é colocado em um violino com cordas de viola, será somente 25 por cento mais pesado que um cavalete de violino porque será da altura de um de violino, aumentase a similaridade do som com a viola.

Adicionando um peso de meio grama na superfície superior do cavalete, o som fica mais similar ainda com o de viola. Adicionado um estandarte ${ }^{42}$ mais pesado - estandartes de violino feitos de ébano pesam em média 12 gramas, os feitos de metal pesam em média 27 gramas, os de viola feitos de ébano pesam em média 17 gramas e os de metal em torno de 38 gramas - o violino transformado agora soa quase como uma viola (BEAMENT, 1977, p. 136).

As violas normalmente requerem mais manufatura que esse violino transformado, uma vez que essa transformação não é completa. O tampo superior de um violino que mede $35,3 \mathrm{~cm}$, com a tap note ${ }^{43}$ afinada em fá com efes e barra harmônica ${ }^{44}$, pesa em torno de 80 gramas. $O$ tampo superior de uma viola que mede $40,7 \mathrm{~cm}$, com a tap note afinada em dó, com efes e barra harmônica, pesa em torno de 125 gramas (BEAMENT, 1977, p. 137). Um tampo mais pesado combinado com um cavalete mais firme exige que os golpes de arco sejam mais firmes, produzindo harmônicos mais agudos mais fortes.

Todas essas diferenças entre o violino e a viola causam efeito no som produzido, mas sem dúvida a mais importante é a proporção do cavalete, que altera o equilíbrio do som, enfatizando os harmônicos mais agudos de cada corda, quando comparando as cordas com a mesma afinação do violino e da viola.

\subsection{Espessura das Lâminas}

A viola tem o tamanho cerca de 1,7 vezes maior que o violino, o que significa que sua área da superfície é maior. Entretanto, a espessura das lâminas de madeira de seus tampos é praticamente a mesma que a do violino, de aproximadamente 3mm (BEAMENT, 1977, p. 62), o que significa que as lâminas de madeira dos tampos da viola são proporcionalmente mais finas que as do violino. Tampos mais

\footnotetext{
${ }^{42}$ Peça que suporta as cordas.

${ }^{43}$ Nota resultante da vibração da madeira quando esta é batida com a articulação do dedo.

${ }^{44}$ Barra de madeira colada por baixo do tampo superior, ao longo da superfície interior. Tem como principal função transmitir as vibrações por todo o corpo do instrumento, a partir do cavalete.
} 
finos são mais flexíveis e, consequentemente, vibram mais com freqüências mais graves. Portanto, a viola possui um registro grave rico e ressonante.

A utilização da caixa de ressonância mais fina e flexível, juntamente com a utilização das cordas mais duras e grossas da viola pode produzir o fenômeno característico do "lobo" 45 , comum nas violas (na nota mi ou fá localizada acima da metade das cordas dó e sol) e violoncelos (uma oitava abaixo que na viola), mas menos freqüente nos violinos. Nessas alturas de som ou freqüências, que são o ponto mais ressonante do instrumento, as lâminas do instrumento vibram em tal intensidade que o cavalete não suporta firmemente, levando a esse efeito.

\subsection{Características do Som}

A viola deve soar diferente do violino. O timbre nasal dos registros mais agudos e o registro grave profundo e ressonante são partes da natureza física e acústica do instrumento.

Apesar de sabermos que a viola deve soar diferente do violino, existem instrumentistas que, consciente ou inconscientemente, ignoram essas diferenças e mantêm um som semelhante ao do violino, tocando com golpes de arco mais leves e evitando utilizar posições ${ }^{46}$ mais baixas na mão esquerda, tocando viola como se estivessem tocando violino.

Hector Berlioz (1948, p.60), em seu Tratado de Orquestração, descreve o som da viola:

[...] de todos os instrumentos da orquestra, aquele cujas excelentes qualidades têm sido subestimadas há mais tempo é a viola. Não é menos ágil que o violino. O som de suas cordas é peculiarmente notável. Suas cordas mais agudas são distinguidas pelo timbre pesarosamente apaixonado; e sua qualidade de som, cheio de profunda melancolia, difere dos outros instrumentos de $\operatorname{arco}(\ldots) .{ }^{47}$

\footnotetext{
${ }^{45}$ Quando há um desequilíbrio de espessura no tampo, e uma determinada nota é tocada, seus sons harmônicos conflitam com a ressonância natural da madeira do tampo, formando um terceiro som, uma vibração muito intensa, que lembra o uivo de um lobo.

${ }^{46}$ A localização da mão esquerda sobre o espelho é classificada pelas posições. Quando o primeiro dedo está posicionado 1 tom acima da corda solta, está na primeira posição. Quando está posicionado no lugar onde o segundo dedo seria colocado se estivesse na primeira posição, está na segunda posição, e assim por diante. As posições denominadas baixas são as que o posicionamento da mão está mais próximo à pestana.

47 "Of all the instruments in the orchestra, the one whose excellent qualities have been the longest misunderstood is the viola. It is no less agile than the violin, the sound of its low strings is particularly telling, its upper notes are distinguished by their mournfully passionate accent, and its quality of tone altogether, profoundly melancholy, differs from that of other instruments played with the bow"
} 
Algumas descrições subjetivas utilizadas para o som da viola são "escuro", "grande", "rico", "aveludado". Juliet White-Smith promove a utilização do que ela chama de "modelos vocais" e seus alunos desenvolvem um conceito de som que reflete a voz contralto da viola ao invés das qualidades de soprano do violino (WHITE-SMITH, 2000, p. 57).

Fazendo-se uma comparação com as tessituras da voz, o violino pode ser classificado como soprano. William Primrose (1904-1992) ${ }^{48}$, em sua autobiografia $A$ Walk on the Northside compara o som da própria viola à voz de uma mezzo soprano ao invés de contralto (PRIMROSE, 1978, p. 165).

Obviamente, todas essas descrições são subjetivas e mudarão de instrumentista para instrumentista. Entretanto, a habilidade de caracterizar o som da viola com descrições subjetivas, especialmente com descrições diferentes daquelas utilizadas para caracterizar o som do violino, faz com que o aluno se conscientize de seu som e auxilia no desenvolvimento do conceito de som.

\subsubsection{Concepção de sonoridade}

William Primrose (1978, p. 173) mencionou que:

O número de violinistas que hoje parecem acreditar que tudo o que devem fazer é possuir uma viola e tocá-la à vontade, para meu desgosto, sem se dar conta de que o que está acontecendo é que estão tocando o que eu sugiro chamar de "rabecão", negando a ela (à viola) sua singularidade, sua sutileza ${ }^{49}$.

Karen Tuttle, uma das mais importantes professoras de viola dos Estados Unidos, enfatiza a importância de o instrumentista reconhecer e "preservar a integridade" do caráter e qualidades únicos, dissociados do violino (DANE, 2002, p. 22).

\footnotetext{
${ }^{48}$ William Primrose, 1904-1992, foi um dos mais importantes violistas e professores de viola, contribuindo para que a viola alcançasse o status de instrumento solista e fosse tratada como um instrumento com características próprias.

49 "The number of violinists today Who appear to believe that all they have to do is possess themselves of a viola, and play away on it to their heart's content and my distress, not realizing for a moment that all that is happening is that they are performing on what I am prompted to call the 'big fiddle', denying it (the viola, thai is) its uniqueness, its quiddity.”
} 
Para entender o que distingue o caráter sonoro da viola, é necessário examinar como as propriedades físicas e acústicas desta diferem das do violino e avaliar as implicações que essas diferenças têm no som da viola. Os dois fatores que afetam mais a sonoridade da viola são seu tamanho e a espessura de suas lâminas de madeira.

\subsubsection{Foco}

Karen Tuttle promove o desenvolvimento do que ela chama de "som grande" - um som de viola focado, penetrante e que pode ser ouvido em qualquer dinâmica (DANE, 2002, p. 30).

Como já foi dito, a viola não possui o timbre brilhante do violino devido às ressonâncias de ar e de madeira e ao conseqüente enfraquecimento dos harmônicos agudos. Se o violinista toca viola sem as modificações apropriadas, como, por exemplo, a pressão apropriada do arco, o som produzido não possui foco. E a ausência deste não somente afeta o caráter, mas também a projeção do som da viola. Muitos ficam tão encantados com o caráter suave do instrumento que se esquecem de tocá-lo com som focado, que é projetado.

Ivan Galamian (1962, p. 102), um dos maiores professores de violino do século XX, salientou a importância da consciência do som: "treinar o ouvido para uma audição objetiva é da maior importância para estar apto a ouvir o som da maneira como o público ouviria e para liberar-se dos enganos lisonjeiros da audição subjetiva". 50

É importante para o violista considerar a dissipação da energia do som à distância e aprender a ouvir o som projetado e focado na perspectiva do público. Para isso, ao tocar, deve utilizar mais peso e velocidade de arco, ataques saindo "da corda", como veremos na parte II.

\footnotetext{
50 "To train the ear for objective listening is of the greatest importance in order to be able to hear the soun as the audience would hear it and to free oneself from the flettering fallacies of the subjective ear"
} 


\subsubsection{Articulação}

A maneira como o ataque ${ }^{51}$ da nota é efetuado é fundamental para definir e caracterizar o som do instrumento, portanto é necessária uma atenção especial a esse aspecto. Estudos demonstraram que, após a gravação de uma nota sustentada, ao remover seu ataque inicial, torna-se impossível ao ouvido humano indicar com precisão qual instrumento está tocando aquela nota (WOODHOUSE, 2010).

As articulações são executadas pelo violista utilizando diferentes técnicas, tais como pressão do arco, a altura da nota no braço do instrumento, o ângulo do arco para tocar as cordas e as diversas posições e movimentos do pulso e/ou do cotovelo, entre outras. $O$ efeito da utilização dessas técnicas diversas resulta na criação de sons diferenciados até mesmo quando notas em uma mesma freqüência são tocadas.

Nos instrumentos de cordas, as articulações de mão esquerda e de mão direita são distintas. A articulação de mão esquerda é a maneira pela qual a mão esquerda funciona, levantando e colocando os dedos nas cordas para a execução das notas.

Em todos os aspectos da execução do violino e da viola, o equilíbrio dos movimentos é fundamental. Este é conseguido através dos movimentos dos braços, mãos e dedos, sendo proporcionais à física dos instrumentos. A falta e o excesso de movimentos são ruins. A presença de movimentos excessivos tira o equilíbrio das mãos, podendo comprometer a linha reta entre o cotovelo e os dedos.

O ponto de equilíbrio da estrutura da mão esquerda deve ser entre os dois dedos do meio (dedo médio e anelar) (BARRET, 1978, p. 58). O pulso deve estar sempre em linha reta com 0 antebraço, 0 que possibilita maior liberdade, flexibilidade, agilidade e relaxamento dos dedos (Figuras 7 e 8).

\footnotetext{
${ }^{51} \mathrm{O}$ ataque determina o tempo que um som demora a atingir seu volume (intensidade) máximo. O tempo de duração do ataque depende de diversos fatores, como o tipo de instrumento musical que é utilizado para gerar o som e técnicas de execução.
} 


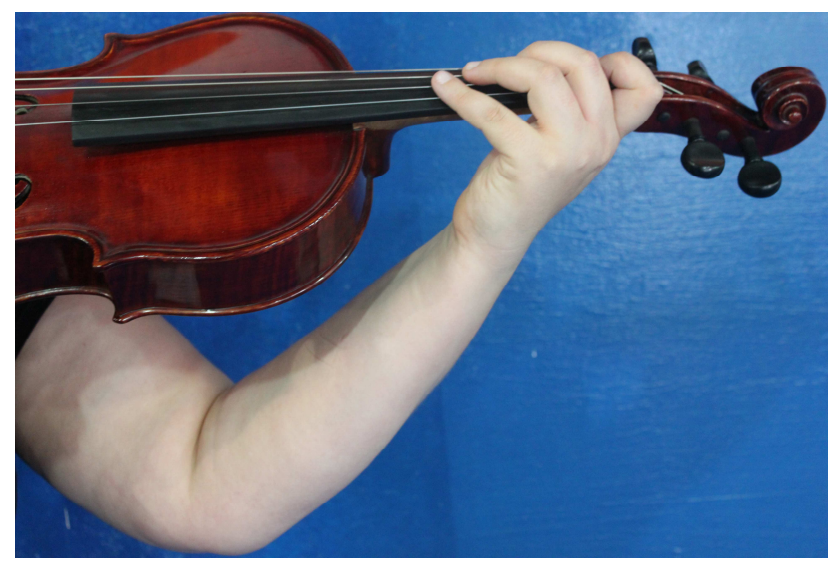

Figura 7 - Posição correta.

Fonte: Imagens captadas pela autora.

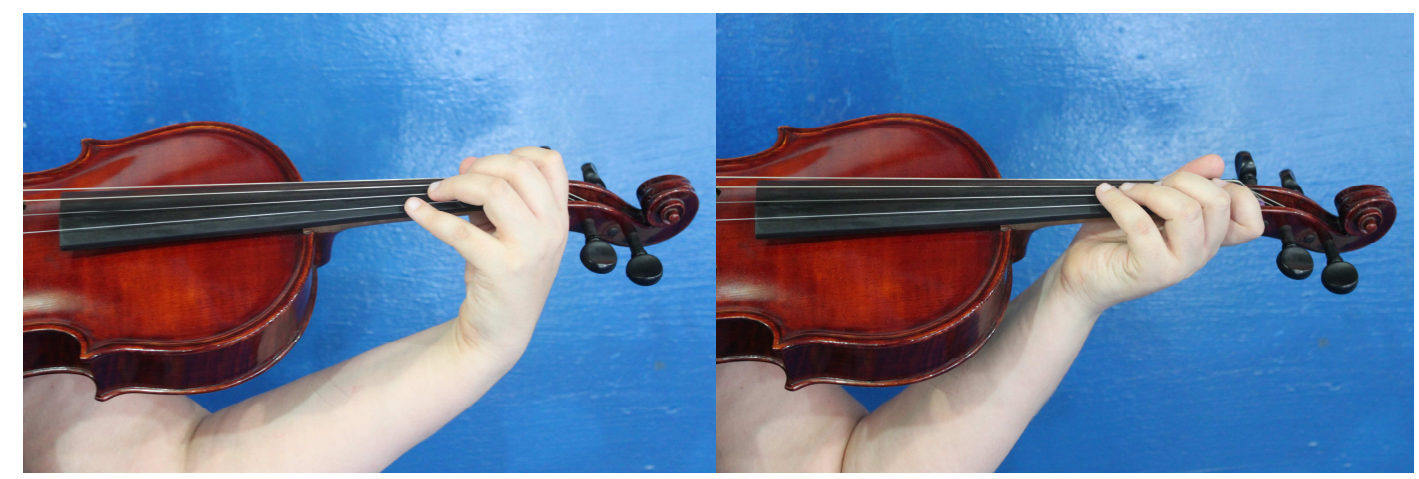

Figura 8 - Posições incorretas.

Fonte: Imagens captadas pela autora.

Ao manter o equilíbrio da mão centralizado nos dedos do meio (médio e anelar), os dedos indicador e mínimo têm maior facilidade de movimento para alcançar a afinação estabelecida sem interferir ou modificar a estrutura. Ou seja, a não ser que o instrumentista tenha uma estrutura óssea fora do normal, como dedos muito longos ou muito curtos, o ângulo da mão deve estar o mais paralelo à linha das cordas possível. Isso faz com que os dedos sejam colocados mais facilmente no ângulo diagonal.

A boa colocação da mão é fundamental para o controle das articulações. A mão não deve ser pressionada contra o instrumento, mas deve, ao invés disso, tocar levemente os dois lados do braço do instrumento. Um lado do braço do instrumento deve estar em contato com o dedo indicador até a terceira posição, a partir do qual o corpo do instrumento apresenta um desafio (GALAMIAN, 1966, p. 15). 


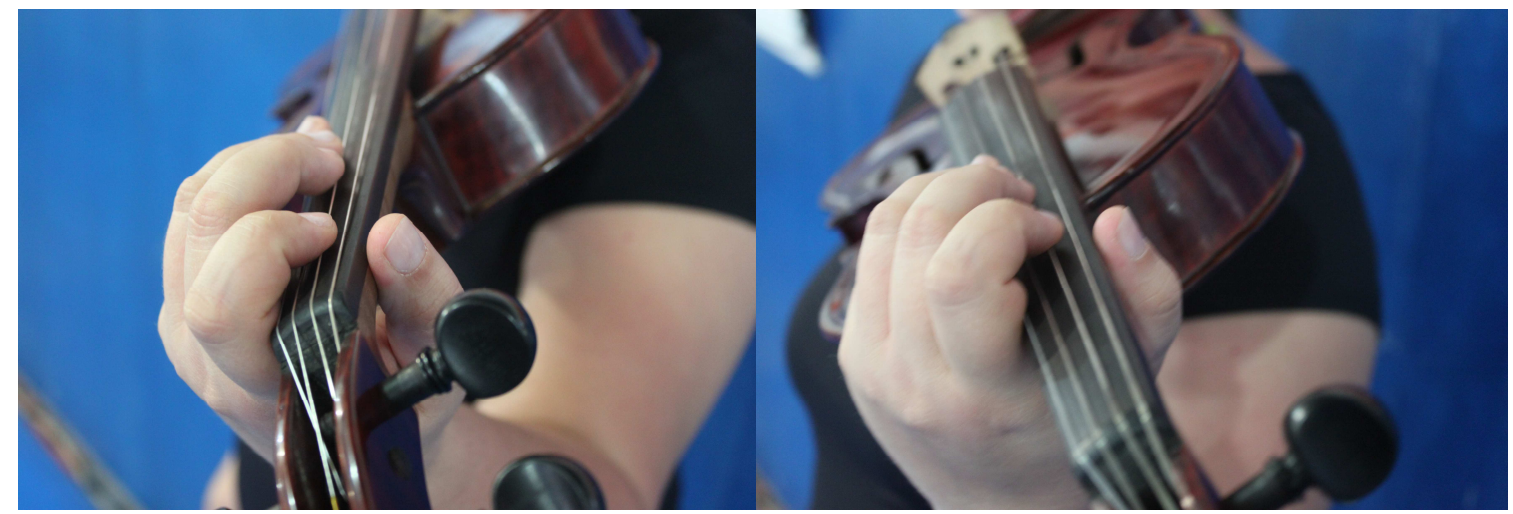

Figura 9 - Mão na primeira posição

Figura 10 - Mão na terceira posição Fonte: Imagens captadas pela autora.

Fonte: Imagens captadas pela autora

O polegar, que equilibra a pressão do dedo médio, deve ser posicionado do lado oposto do braço do instrumento. Cada dedo, em qualquer posição que a mão esteja, deve funcionar independentemente, sem tirar a mão ou os outros dedos de sua posição. O polegar assume uma posição média entre a ponta do dedo e a primeira articulação (DALTON, 1988, p. 130), dependendo da estrutura óssea do instrumentista. Deve-se manter os dedos relaxados. (Figuras 9, 10 e 11)

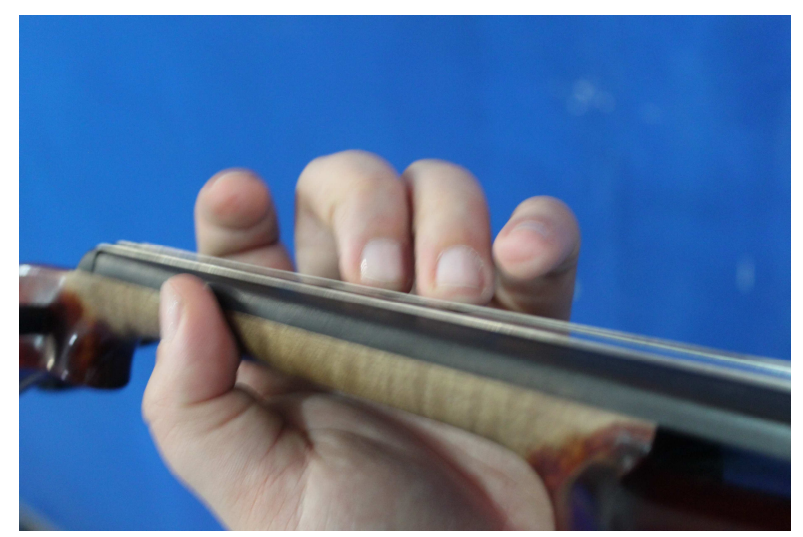

Figura 11 - A forma da mão.

Fonte: Imagens captadas pela autora.

A forma da mão não deve variar com dedilhados, mudanças de cordas, mudanças de posição, vibrato, trinados e cordas duplas (BARRETT, 1978, p. 57). O cotovelo deve ser o fator principal para as mudanças de cordas, pois causa menos rompimento à integridade total da forma ao manter a linha reta do pulso até o antebraço. 


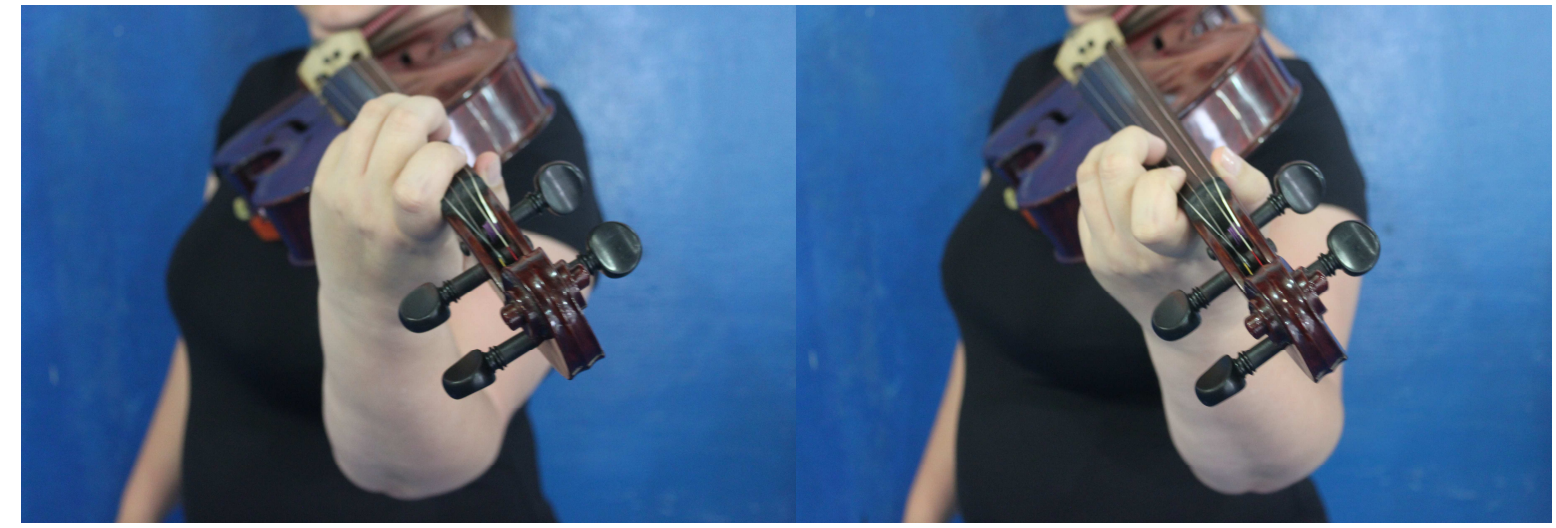

Figura 12 - Posições corretas.

Fonte: Imagens captadas pela autora.

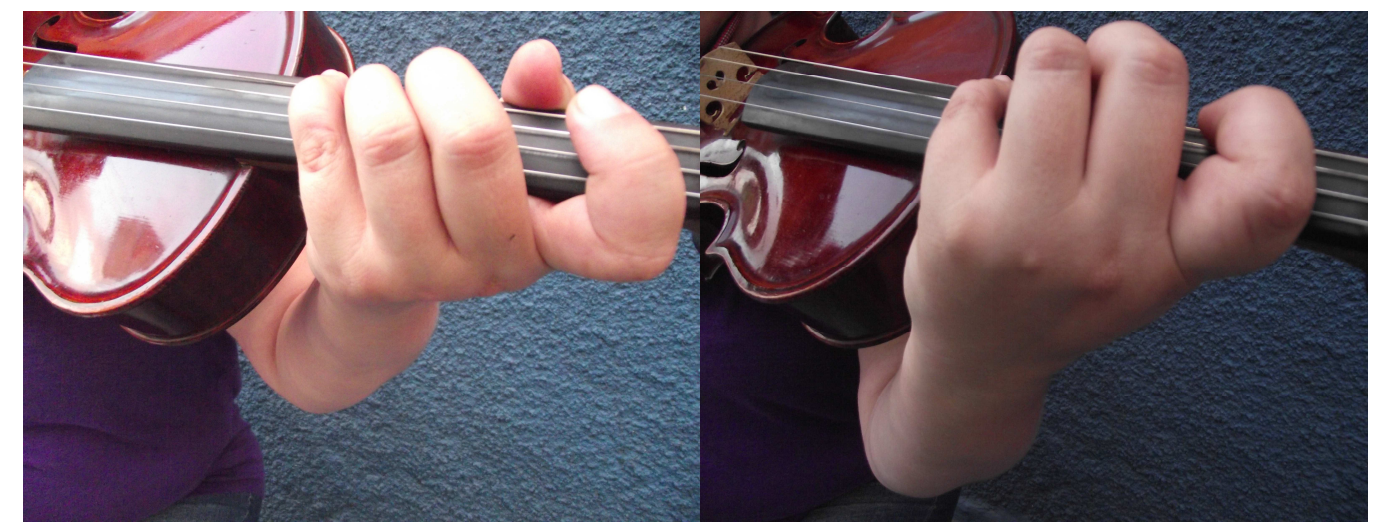

Figura 13 - Posições incorretas.

Fonte: Imagens captadas pela autora.

É um erro comum o instrumentista mudar de corda girando o pulso esquerdo, o que quebra a linha reta e altera o ângulo no qual os dedos se aproximam das cordas (Figuras 12 e 13). Como na figura 12, o cotovelo se movimenta acompanhando o posicionamento da mão sobre as cordas.

Quando o instrumentista está tocando na primeira, segunda, terceira e, às vezes, na quarta posição, a distância do eixo do cotovelo é proporcional à distância entre a cordas. Esse movimento deve ser suave, proporcional à distância necessária para que o braço permaneça flexível. O movimento nunca deve ser exagerado.

Qualquer movimento sem controle dos dedos somente prejudica sua precisão mandando estímulos conflitantes ao cérebro. Portanto, é através da prática que o instrumentista adquire a memória muscular necessária para ensinar aos dedos o movimento correto para por e tirar os dedos das cordas em articulações claramente executadas. 
O movimento do dedo deve iniciar na articulação, levantando o dedo como um pizzicato ${ }^{52}$ leve. Deve-se golpear a corda com o dedo no local da nota e levantálo rapidamente, com a mesma energia, produzindo um som "seco" (BARRET, 1978, p. 60). A queda "vertical" dos dedos não é possível se o instrumento estiver apoiado na palma da mão.

São três os passos para uma boa execução da articulação: preparação, execução e relaxamento. São aplicáveis tanto para os movimentos de colocar quanto de tirar os dedos das cordas. Para colocar, a preparação exige a volta do dedo à posição, pronto para ser colocado. $O$ grau do movimento da volta depende do ritmo e tempo. Esse movimento da volta é imediatamente seguido pela colocação dos dedos na corda.

Durante a fase de colocação, ou execução, os dedos devem atuar como martelos mecânicos que dão um golpe e então retornam ao ponto original de equilíbrio (entre os dois dedos do meio, anelar e médio). Ambos os movimentos de queda e subida devem ser equilibrados tanto rítmica quanto fisicamente. A velocidade na qual o movimento é executado é importante para encontrar esse equilíbrio. O movimento de queda deve seguir a direção do dedo. Geralmente a direção do dedo é um ângulo diagonal, que depende da estrutura óssea do instrumentista. Após o dedo dar o golpe na corda, deve-se imediatamente tirar a tensão, deixando o dedo novamente relaxado, enquanto é preparado para o próximo movimento. Isso permanece até que o cérebro determine qual o próximo dedo a ser utilizado.

Os três estágios relativos ao movimento de levantamento do dedo são:

(1) Preparação, que envolve o planejamento do movimento;

(2) Execução. O levantamento, como a queda, deve seguir a direção "em movimentos laterais suaves de forma que ocorra um leve pizzicato de mão esquerda" (DALTON, 1988, p. 137).

(3) Queda. É importante não manter os dedos repousados nas cordas antecipadamente.

Os movimentos de queda e levantamento mais efetivos são impulsionados pelas articulações da mão esquerda. É errônea a utilização do pulso ou de outras partes do braço para completar o movimento. As articulações executam essa tarefa

\footnotetext{
${ }^{52}$ Palavra italiana para beliscado. Utilizada como instrução para dedilhar a corda ao invés de utilizar o arco, geralmente feito com a mão direita.
} 
mais eficientemente; o envolvimento de mais partes do corpo só atrasa o movimento, interferindo com o resultado final. $\mathrm{O}$ movimento mais efetivo é realizado quando o movimento é minimizado.

O movimento completo, envolvendo a queda e o levantamento dos dedos, é similar ao rebote de uma bola de tênis quando bate em uma parede. O tenista puxa e estica o braço, bate na bola, lançando-a com velocidade contra a parede, e subsequentemente há o rebote após o impacto.

É importante que os dedos caiam e levantem em uma velocidade similar. Alguns dedos têm a tendência de cair um pouco rápido, criando desigualdade de articulação e ritmo. Cada nota deve ocupar o espaço no tempo de sua ação. A velocidade apropriada aumenta a liberdade de movimento. De acordo com Barrett (1978, p.60), é importante que: "cada nota da escala seja ouvida claramente. A maioria dos instrumentistas corre no início e no final, quando precisam ser mais claros. Um leve atraso no início e no final dá estabilidade e previne a queda na nota final". 53

A execução da articulação no violino e na viola é bastante similar. Na viola, pelo fato de as cordas serem maiores e mais grossas, existe uma maior dificuldade.

Além de sua execução usual de articulação, os dedos da mão esquerda também possuem a habilidade de executar um número de diferentes "efeitos especiais". São os pizzicatos de mão esquerda, trinados, glissandos cromáticos e harmônicos.

Pizzicato de mão esquerda é aquele no qual a corda é puxada com os dedos da mão esquerda. Isso exige que o dedo que toca a nota esteja no lugar antes do movimento de levantamento do dedo. O cotovelo deve estar mais para a esquerda, para que a parte do dedo que tem mais polpa tenha contato com a corda. $O$ dedo que segura a nota a ser tocada deve estar colocado firmemente (GALAMIAN, 1966, p. 30). O movimento que o dedo faz para puxar a corda deve ser circular.

Os trinados exigem que dois dedos trabalhem em revezamento, um após o outro. Antes de iniciar o trinado, o instrumentista deve saber a velocidade e o número de repetições em cada batida (BARRET, 1978, p. 60). É importante que o dedo que se move permaneça próximo à corda, sem fazer movimentos com força

\footnotetext{
53 "Each note of a run should sound clearly. Most players rush at the beginning and end of runs, crucial points at which each note must be audible. The slightest slowing up at the end of a run gives poise and prevents a falling into the final note"
} 
demasiada na execução, mas como um movimento leve de tamborilamento. $\mathrm{O}$ movimento de levantar o dedo é tão importante quanto o de descer e deve ser executado como um leve pizzicato de mão esquerda para dar mais clareza (GALAMIAN, 1966, p. 30).

Surgem alguns problemas relativos à execução dos trinados quando o dedo que permanece fixo na corda exerce pressão exagerada na corda. Essa tensão impede que o outro dedo se mova livremente. Há dois tipos de trinados: de vibrato e de dedo. Os trinados de vibrato são aqueles que, como o próprio nome diz, são executados com os movimentos do vibrato. Os trinados de dedo, por outro lado, não utilizam os movimentos do vibrato e, no geral, obtêm melhor articulação, facilitando a audição do intervalo do trinado.

Devido ao tamanho e ressonância do instrumento, na viola o trinado deve ser executado um pouco mais lentamente que no violino.

O glissando cromático é similar ao staccato na mão direita. O dedo que executa o glissando deve ser preferencialmente esticado, com o pulso curvado para o lado externo em direção à voluta, mantendo a tensão na mão e no braço (GALAMIAN, 1966, p. 34). O glissando cromático também pode ser comparado ao movimento do vibrato.

Os harmônicos artificiais são outro "efeito especial" que deve ser mencionado, devido à sua freqüente utilização no repertório. Há uma diferença de pressão entre o dedo mais baixo, colocado firmemente sobre a corda e o dedo mais agudo, que toca levemente a corda (GALAMIAN, 1966, p. 31).

Ao tocar um harmônico, é importante que sejam mantidas a pressão e a velocidade constantes do arco, para não afetar a emissão da nota. Há golpes de arco que auxiliam na articulação, como o martele $e^{54}$ e o collét ${ }^{55}$. Nestes golpes de arco, enquanto há a parada na corda ou no ar, o dedo tem tempo para preparar-se para a nota seguinte. Isso auxilia na coordenação entre ambas as mãos e cria uma uniformidade no ritmo, assim como a preparação cria uma percepção no ritmo entre o arco e a mão esquerda (FLESCH, 1930, p. 34-35).

\footnotetext{
${ }^{54}$ Técnica de arco utilizada para a produção de notas destacadas e fortemente acentuadas, executada na ponta do arco, sem que este deixe a corda.

${ }^{55}$ Golpe de arco semelhante ao martelé, mas é executado no talão.
} 


\subsubsection{Espessura das cordas}

É importante entender a viola sob a perspectiva da clareza da articulação por causa das suas características físicas. O peso do tampo superior de um violino de $35 \mathrm{~cm}$ de medida com espessura tap note em fá é de aproximadamente $80 \mathrm{~g}$. $\mathrm{O}$ tampo superior de uma viola 40 com espessura tap note em dó pesa em torno de 125g. sendo, portando, 1,5 vezes mais pesada que o violino ${ }^{56}$ (BEAMENT, 1977, p. 137).

As cordas da viola são mais grossas em relação às cordas do violino que se encontram na mesma posição. Ou seja, a corda lá da viola é mais grossa que a corda mi do violino. A densidade das cordas também é modificada de acordo com o material com que é feita, como por exemplo, a prata e o tungstênio.

Tabela 3 - Cordas Jargar com centro de aço (em $\mathrm{mm}$ )

\begin{tabular}{lrrrr}
\hline $\begin{array}{l}\text { Cordas Jargar } \\
\text { com centro de }\end{array}$ & $4^{\text {a }}$ corda & $3^{\text {a }}$ corda & $2^{\text {a }}$ corda & $1^{\text {a }}$ corda \\
aço $(\mathrm{em} \mathrm{mm})$ & & & & \\
\hline Violino & 0,75 & 0,72 & 0,45 & 0,26 \\
Viola & 1,08 & 0,79 & 0,73 & 0,44 \\
\hline
\end{tabular}

Fonte: Adaptado pela autora.

Os fabricantes de cordas aumentam a espessura e a densidade da corda para obter afinações mais graves.

$\mathrm{Na}$ viola, assim como em todos os instrumentos de cordas, o comprimento da corda vibrante ${ }^{57}$ permanece constante em todas as cordas. Portanto, para obter afinações mais graves, aumenta-se o diâmetro/espessura e a densidade/massa da corda.

O aumento da massa do instrumento e de suas cordas tem duas implicações fundamentais. Primeiro, necessita de mais energia para ultrapassar a inércia inicial da viola. Ou seja, é necessária a utilização de mais energia do arco para fazer a viola vibrar. Segundo, uma vez que o instrumento está vibrando, ele adquire mais

\footnotetext{
${ }^{56}$ Tap note refere-se ao som que é produzido quando alguém segura a lâmina do instrumento perto de uma extremidade entre o polegar e o dedo médio e bate em diversos pontos, ouvindo as notas resultantes. (evidentemente com o instrumento desmontado). Ao lixar a lâmina, o luthier pode modificar esse som.

${ }^{57}$ Parte da corda que vibra, situada entre o cavalete e a pestana.
} 
cinética $^{58}$ e, consequentemente, mais energia é necessária para abafar as vibrações.

A viola é um instrumento que ressoa mais que o violino, pois suas cordas são maiores e mais espessas, e a maneira como se abafa o som resulta em implicações imediatas para se controlar a articulação e a pureza do som. Muita ressonância tira a clareza do som. Segundo Beament (1977, p. 93):

\begin{abstract}
Ressonância é essencial, mas clareza e rapidez de resposta estão particularmente associadas com um abafamento interno adequado na madeira (assim como nas cordas), porque o abafamento assegura que $o$ instrumento não continue a vibrar com um conjunto de frequências [...] quando a corda tocada com arco está produzindo diferentes frequências e diferentes dinâmicas. ${ }^{59}$
\end{abstract}

Podemos concluir que a viola possui uma resposta de ataque mais lenta e uma dissolução de som mais longa que a do violino. É importante enfatizar essas diferenças a fim de se obter a sonoridade característica da viola.

\title{
3.5. Arco do Instrumento
}

As cordas são colocadas em vibração pela fricção com um arco. É uma peça de madeira longa, de curvatura convexa, com um conjunto de fibras feitas de crina de cavalo presas a suportes em suas extremidades.

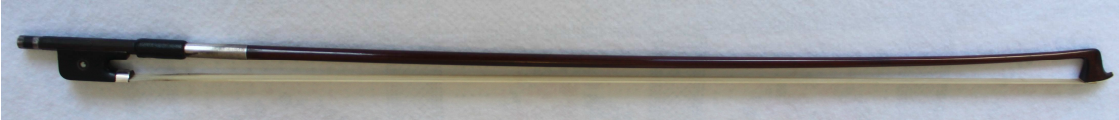

Figura $14-\mathrm{O}$ arco.

Fonte: Imagens captadas pela autora.

A forma convexa ${ }^{60}$ do arco faz com que a tensão das crinas se mantenha inalterada quando o executante as pressiona contra as cordas. Assim, o executante

\footnotetext{
${ }^{58}$ Processo ou mecanismo pelo qual se dá certa alteração física ou química.

59 "Ressonance is essencial, but clarity and rapidity of response are particularly associated with adequate internal damping in the wood (as well as in the strings), because damping ensures that the instrument does not continue to vibrate with one set of frequencies in their respective sizes when the bowed string is producing different frequencies and different dynamic"

${ }^{60}$ Que forma uma saliência arredondada para fora, como a parte externa de um círculo ou de uma esfera.
} 
obtém um som firme e homogêneo em qualquer parte que o arco esteja, em contato com as cordas.

O movimento de uma corda friccionada por um arco envolve um processo do tipo "prende-desliza". Para aumentar o atrito entre as fibras da crina do arco e as cordas do violino, as fibras são impregnadas com breu ${ }^{61}$. Ao passar o arco sobre a corda, este a segura e a desloca. A corda então se movimenta por cerca de $1 \mathrm{~mm}$, e em seguida a resiliência ${ }^{62}$ aumenta a ponto de vencer o atrito e a corda é liberada, deslizando pelas crinas até ser presa novamente, recomeçando o ciclo, que se repete com a frequência da nota tocada.

Ao ser friccionada, a corda forma dois segmentos retos unidos no chamado ponto de dobra. No início, esse ponto coincide com o ponto de contato entre as crinas e a corda. No entanto, com a continuação do movimento do arco, o ponto de dobra desloca-se ao longo da corda e sofre reflexão nas extremidades desta.

A grande velocidade com que isso acontece impede que vejamos esses segmentos: podemos ver apenas os dois arcos parabólicos ${ }^{63}$ descritos pelo movimento do ponto de dobra.

As propriedades físicas da viola exigem que o violista despenda mais energia com o arco na corda para conseguir caráter, foco e clareza no som. Os $\operatorname{archetiers~}^{64}$ já fizeram tentativas de compensar em certo grau essa exigência.

Um arco de viola é similar ao do violino em comprimento (em alguns caso, 1 $\mathrm{cm}$ mais curto - $72 \mathrm{~cm}$ ao invés de $73 \mathrm{~cm}$ ) e pesa cerca de 70 gramas (sendo que o do violino pesa 60 gramas). As medidas da ponta e do talão também são levemente mais largas e mais altas que as do violino, cerca de $1 \mathrm{~mm}$ ao todo, o que faz com que o arco fique mais forte para suportar mais peso ou pressão do braço do instrumentista. A madeira é levemente mais densa, mas similar em firmeza, significando que um arco de viola vibra em freqüências mais baixas que o de violino, auxiliando na emissão da sonoridade da viola.

A utilização do arco de viola auxilia o instrumentista, mas por si só não é suficiente para o aperfeiçoamento da produção de som, já que o arco da viola é

\footnotetext{
${ }^{61}$ Resina obtida de seiva de pinheiros.

62 Tendência a retornar à posição original

${ }^{63}$ Que tem a forma semelhante à de uma parábola, lugar geométrico dos pontos em um plano cujas distâncias a um ponto fixo e uma reta fixa são iguais.

${ }^{64}$ Artesãos que produzem arcos.
} 
somente 1,16 vez mais pesado que o do violino, enquanto a viola padrão é 1,5 vez mais pesada que o violino.

É necessária a utilização de uma técnica específica de mão direita, diferente da de violino, para produção de som na viola. 


\section{PARTE II}

\section{Capítulo 1 - Execução no que concerne à mão direita}

O som no violino e na viola é produzido através do arco, que faz com que as cordas vibrem, produzindo sons que podem ser modificados de acordo com a finalidade musical. Produzir e modificar o som significa entender como o arco faz a corda vibrar e as variáveis afetam a corda vibrante. Estas variáveis são a pressão do arco na corda, a velocidade na qual o arco é puxado e o ponto de contato do arco na corda. As variáveis interdependentes que, modificadas, afetam umas às outras.

O controle de arco é a habilidade de manipular cada uma dessas variáveis em qualquer parte do arco. Um fator que é fundamental para a produção de um som de qualidade é que o arco deve permanecer em linha reta, paralelo ao cavalete, embora algumas escolas advoguem a utilização do arco levemente em diagonal.

Segundo Beament (1977), a resistência tem um papel primordial na vibração da corda. O peso do braço do instrumentista contribui para isso, exercendo uma força vertical no arco. O cavalete sustenta a corda, opondo-se contra o peso do braço, criando esta resistência. Como resultado, a resistência do arco contra a corda é maior quando se toca mais próximo ao cavalete, possibilitando a utilização de uma grande quantidade de peso do arco. $O$ peso deve ser diminuído à medida que o arco se aproxima do espelho. Muito peso do braço, quando tocado próximo ao espelho, impossibilita a corda de vibrar. A quantidade de peso do braço utilizada pra a produção do som, portanto, é diretamente ligada à escolha do ponto de contato. $O$ peso maior do braço exige um ponto de contato mais próximo ao cavalete, o peso menor do braço exige um ponto de contato mais longe, próximo ao espelho.

O arco deve também ser movimentado mais lentamente quando próximo ao cavalete devido à resistência, para que a corda vibre. Do mesmo modo, o arco pode ser movimentado mais rapidamente quando há menos resistência, mais longe do cavalete.

Em geral, a corda vibrará melhor se o arco se movimentar mais lentamente com mais peso do braço próximo ao cavalete, mais rapidamente com menos peso do braço próximo ao espelho. 
Há duas outras considerações sobre o ponto de contato: a espessura e o comprimento das cordas. No violino, a corda mi é a mais fina, na viola, a lá. À medida que vão ficando mais graves, (lá, ré e sol no violino e ré, sol e dó na viola) vão tornado-se mais espessas. As cordas mais finas vibram melhor quando seu ponto de contato é mais próximo ao cavalete, as mais espessas, quando mais longe do cavalete.

Os dedos da mão esquerda do instrumentista são outra variável, constantemente modificando o comprimento da corda que está vibrando, encurtando-a ao colocar o dedo e encompridando-a ao tirar o dedo. Para produzir a melhor sonoridade, o arco deve ter seu ponto de contato mais próximo ao cavalete para as cordas com comprimento menor, e com ponto de contato mais próximo ao espelho para as cordas com maior comprimento.

Todos esses fatores contribuem para a produção do som. Existe uma combinação de peso do braço, velocidade do arco e ponto de contato em uma espessura e comprimento específicos que fazem com que a corda vibre em seu potencial máximo. Como já foi mencionado, a modificação de qualquer uma dessas variáveis afetará as outras e, consequentemente, o som produzido. Compreender e controlar o peso do braço, a velocidade do arco e o ponto de contato é essencial para criar um grande número de cores e qualidade de som.

Quando uma corda é friccionada por um arco, a oscilação é sustentada por mais tempo e a relação entre o som fundamental ${ }^{65}$ e seus parciais ${ }^{66}$ é praticamente harmônica. A forma da onda resultante tem como característica um espectro de som rico em harmônicos. No violino, esses harmônicos são afetados pelas vibrações e ressonâncias do cavalete e do corpo do instrumento (incluindo as ressonâncias dos tampos e do ar em seu interior), que reforçam e amplificam os componentes do som com frequências nessas ressonâncias. O som do violino, portanto, resulta da forma de onda ${ }^{67}$ originada pela excitação das cordas pelo arco, modulada pelas vibrações e ressonâncias do corpo do violino, de seus tampos e do cavalete, que reforçam os harmônicos cujas frequências coincidem com as dos modos normais de vibração desses corpos. O resultado é um espectro de som cujos componentes terão

\footnotetext{
${ }^{65}$ Som mais grave de uma seqüência harmônica, sendo divisor de todos os outros sons desta sequiência.

${ }^{66}$ Série de sons partícipes de outros sons, comumente denominados harmônicos.

${ }^{67}$ Representação gráfica da forma com que uma onda evolui ao longo do tempo.
} 
diferentes intensidades como resultado da influência de todas essas multirressonâncias $^{68}$.

O som que ouvimos quando um violino é tocado é a soma de vários componentes. Como podemos observar na figura 14, o arco faz a corda vibrar, produzindo uma onda do tipo "dente de serra" e um espectro de som rico em harmônicos (A). As vibrações e ressonâncias do corpo do instrumento $(B)$ e do cavalete (C) reforçam os harmônicos do espectro sonoro cujas frequências coincidam com as frequências dos modos normais dessas vibrações. O resultado é um espectro de som com componentes de diferentes intensidades (D), em função da influência de todas essas multirressonâncias. A forma de onda de saída ${ }^{69}$ foi obtida tocando a nota Ré. (DONOSO et al, 2008, p.25)

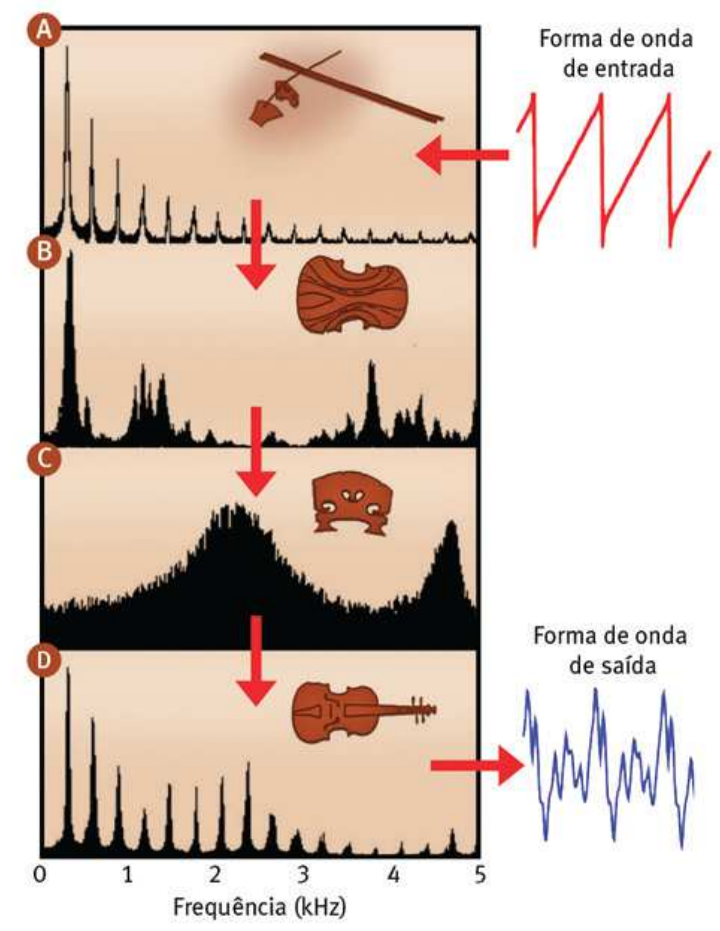

Figura 15 - Forma de onda de saída.

Fonte: DONOSO, 2010, p. 25.

\footnotetext{
${ }^{68}$ Ressonância é a tendência de um sistema a oscilar em máxima amplitude em certas frequiências, conhecidas como 'frequências ressonantes'. Nessas frequências, até mesmo forças periódicas pequenas podem produzir vibrações de grande amplitude, pois o sistema armazena energia vibracional. Quando o amortecimento é pequeno, a frequência de ressonância é aproximadamente igual a frequência natural do sistema, o que é a frequência de vibrações livres. O fenômeno da ressonância ocorre com todos os tipos de vibrações ou ondas; mecânicas (acústicas), eletromagnéticas, e funções de onda quântica. Sistemas ressonantes podem ser usados para gerar vibrações de uma frequência específica, ou para obter frequências específicas de uma vibração complexa contendo muitas freqüências.

${ }^{69}$ Forma da onda que soa a nota ré no timbre do violino.
} 
Presumindo-se que tenha os mesmos objetivos sonoros, a execução dos instrumentos de arco, de modo geral, obedece a princípios físicos comuns. Partindo dessa premissa, é possível empreender uma análise do uso do arco a partir das técnicas adotadas pelos principais didatas e teóricos modernos, entre os quais podemos incluir os violinistas Leopold Auer (1845-1930), Carl Flesch (1873-1944) e Ivan Galamian.

As principais escolas de arco do violino e da viola podem ser divididas em duas principais vertentes: a Franco-Belga e a Russa. A esses grupos principais também podem ser acrescentadas algumas outras correntes do arco do violino: as escolas Franco-Belga-Russa, de Carl Flesch, a escola Italiana, de Zino Francescatti (1902-1991), a escola Checa, de Otakar Sevcík (1852-1934) e a moderna escola Norte-americana, de Ivan Galamian (1903-1981).

Antes de abordarmos essas correntes, é importante lembrar que a escola Alemã foi também largamente utilizada no passado pelos músicos da Europa. Os que empregavam essa técnica trabalhavam com os dedos da mão direita praticamente juntos, a crina levemente tensa. Essa escola foi cedendo gradativamente lugar a outras tendências.

A escola Russa é atribuída ao violinista polonês Henryk Wieniawsky (18351880), mas foi definitivamente consolidada por Leopold Auer, seu sucessor no Conservatório Imperial de São Petersburgo a partir de meados do século XIX.

Apesar de a escola Russa ter sido bastante utilizada naquela época, a corrente conhecida como Franco-Belga, de Charles de Beriot (1802-1870), Cesar Thompsom (1857-1931) e Eugène Ysaÿe (1858-1931), atualmente é a mais difundida e adaptada entre os demais países europeus e Estados Unidos.

Joseph Joachim (1831-1907) segurava o arco utilizando apenas os dedos médio, anelar e mínimo, dispensando o indicador. Ysaÿe, ao contrário, empregava o indicador, médio e anelar, levantando o dedo mínimo. Sarasate (1844-1908), por sua vez, apoiava todos os quatro dedos sobre a vareta do arco, mas contornava a aparente excessiva firmeza utilizando a flexibilidade dos dedos com maestria (AUER, 1980, p. 13).

Auer (1980), o consolidador da escola Russa, enumerou os principais fundamentos de sua técnica de arco. Concebeu que pode ser compreendida como a ação do polegar e demais dedos da mão direita, a flexibilidade do pulso e a atuação integrada do braço e antebraço direitos. Concluiu, também, que o dedo indicador 
deveria se apoiar sobre a vareta entre a segunda e a terceira articulações dos dedos, sendo ele o principal responsável pela elasticidade na condução do arco e pela enorme e rica diversidade de formas de produção do som. O dedo médio, por sua vez, seria secundário na movimentação, devendo ser colocado de forma quase que diametralmente oposta ao polegar, enquanto o dedo anelar trabalharia próximo ao médio, subordinado a ele. Finalmente, a ponta do dedo mínimo seria apoiada levemente no extremo da vareta, nunca devendo ser levantado. Leopold Auer (1980) defende, também, em sua técnica, a ação coordenada dos músculos do braço e antebraço e a utilização bastante flexível do pulso.

Esta seria a forma de compensar qualquer possível rigidez advinda do apoio do dedo mínimo sobre a vareta do arco - ao contrário, por exemplo, da escola Franco-Belga, que obtém maior flexibilidade pela utilização articulada quase exclusivamente pelos dedos indicador, médio e anelar.

Para movimentar o arco para baixo, Auer (1980) propõe que o pulso se mova naquela direção, deslocando-o gradualmente até que a crina do arco deslize sobre a corda, produzindo o som. Para deslocar o arco para cima, o pulso deve exercer movimento semelhante em direção contrária. Na escola Russa, o braço se desloca de forma confortável, nem muito perto, nem afastado do corpo, devendo empregar uma movimentação natural. Quando se trabalha sobre a primeira e a segunda cordas, o pulso deve ser colocado em nível mais alto do que quando a terceira ou quarta cordas são utilizadas. A crina não deve estar muito tensa, e deve deslizar perpendicularmente à corda.

Em vista desses fatores, pode-se compreender porque existe, entre os adeptos dessa escola, certa facilidade na projeção do som, com menor esforço do executante, e uma sonoridade que se pode descrever como densa, compacta (AUER, 1980, p. 20).

$\mathrm{Na}$ escola Franco-Belga, o indicador trabalha em contato com a vareta do arco no extremo da segunda articulação do dedo, e o polegar em posição oposta ao dedo médio. A crina deve ser utilizada com razoável tensão de forma ligeiramente inclinada em direção ao executante (Figura 16). 


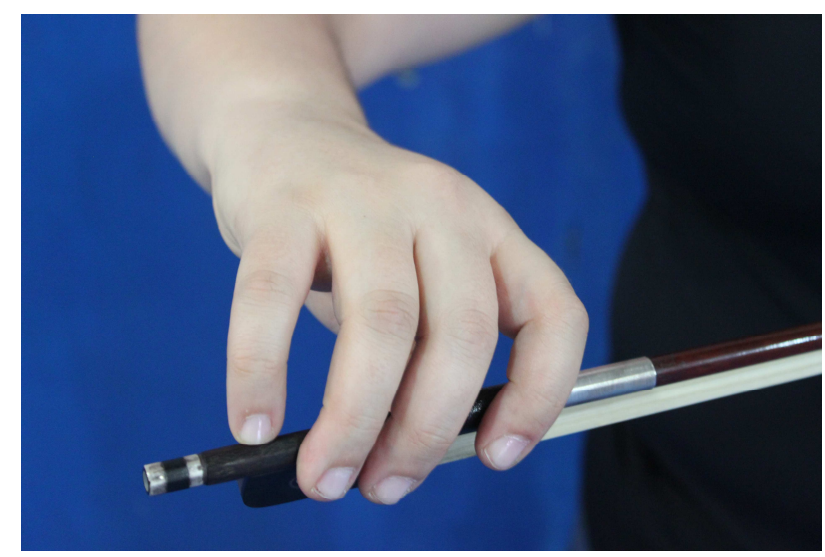

Figura 16 - Escola franco-belga de arco.

Fonte: Imagem captada pela própria autora.

Faremos abaixo algumas considerações a respeito da maneira de segurar 0 arco da viola, independentemente da escola a ser utilizada. $^{70}$

A primeira é que se deve segurar o arco da viola firmemente e ainda assim manter a flexibilidade. Para alguns violinistas, isso significa segurar mais firmemente que o arco do violino.

Primrose descreve sua experiência pedagógica: "Enfatizo a importância da firmeza e flexibilidade do ato de segurar o arco [...] Um ato de segurar o arco negligente, frouxo, produzirá um som vago e sem corpo"71 (PRIMROSE, 1988, p. 176). Ele defende a maneira de segurar o arco mais como um violoncelista envolvendo a vareta muito mais amplamente do que é prática comum no violino (Figura 17).

\footnotetext{
${ }^{70}$ Escolas Russa, Alemã e Franco-Belga são as mais conhecidas.

71 "I emphasize the importance of a firm and supple grip[...]. A careless, loose grip will produce a tone that is fuzzy and lacking in body.”
} 

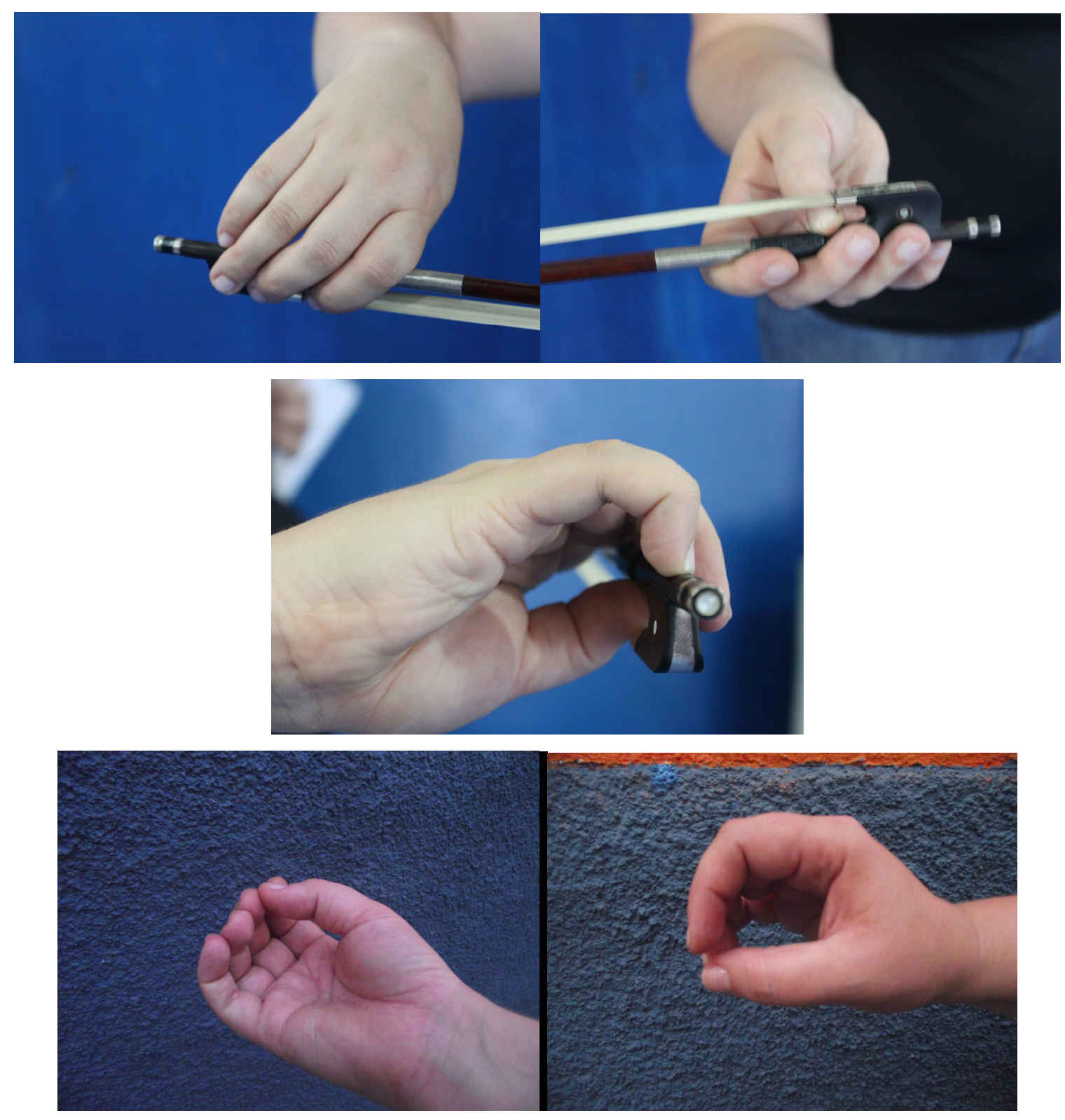

Figura 17 - Maneira de segurar o arco.

Fonte: Imagens captadas pela autora.

A segunda consideração é que a maneira de segurar o arco deve ter um ângulo de crina plano na viola, ou seja, toda a crina sobre a corda. Tanto Tuttle quanto Primrose são explícitos nesse ponto (TOPPER, 2002, p. 106). Quanto mais plano for o ângulo do arco na corda, maior o som produzido sem aumento da força, de acordo com a experiência de vários instrumentistas de corda (TOPPER, 2002, p. 37-39).

A terceira consideração é que, embora exista a escola na qual os violinistas seguram o arco com o polegar situado entre o primeiro dedo (indicador) e o segundo 
dedo (médio), existe uma escola que sugere que o polegar esteja situado entre o segundo e o terceiro dedos, o que faz aumentar a distribuição do peso através de todo o arco.

Em nossa opinião, a localização do polegar entre o primeiro e segundo dedos funciona melhor na viola, pois favorece o apoio do peso do braço no primeiro dedo, obtendo, assim, mais pressão na corda.

\subsection{Peso do Arco}

A maneira mais simples de aumentar a quantidade de energia transmitida pelo arco na corda é aumentar a quantidade de pressão ou de peso aplicados no arco. O fator crítico que todas as fontes pedagógicas concordam é que o aumento do peso do arco não deve ser gerado pela pressão muscular para baixo, mas pelo efeito natural da gravidade e do peso do arco. Primrose (DALTON,1988, p. 62) dizia que:

[...] pressão e tocar viola são imiscíveis. Enquanto eu desenvolveria a opinião de que a pressão não é o melhor artifício para a produção de som no violino, o violinista pode escapar com o fato de que seu instrumento responde mais prontamente do que o nosso. O nosso tem de ser persuadido e conquistadoo e ressentido grosseira e excessivamente. $^{72}$

Não é possível encontrar dados que sustentem a hipótese de Primrose (DALTON, 1988) de que o violino é menos sensível aos efeitos da pressão que a viola. Os dados disponíveis sustentam a noção de que existe uma quantidade máxima (e mínima) de força no arco para baixo (dependendo da velocidade do arco e da distância do cavalete), antes que a qualidade do som seja afetada em qualquer instrumento.

\footnotetext{
72 “[...] pressure and viola playing are immiscible. While I woud advance the opinion that pressure is not the best device for tone production on the violin, the violinist may get away with it in that his instrument responds more readily than does ours. Ours has to be wooed and won and resents manhandling and outrage”.
} 


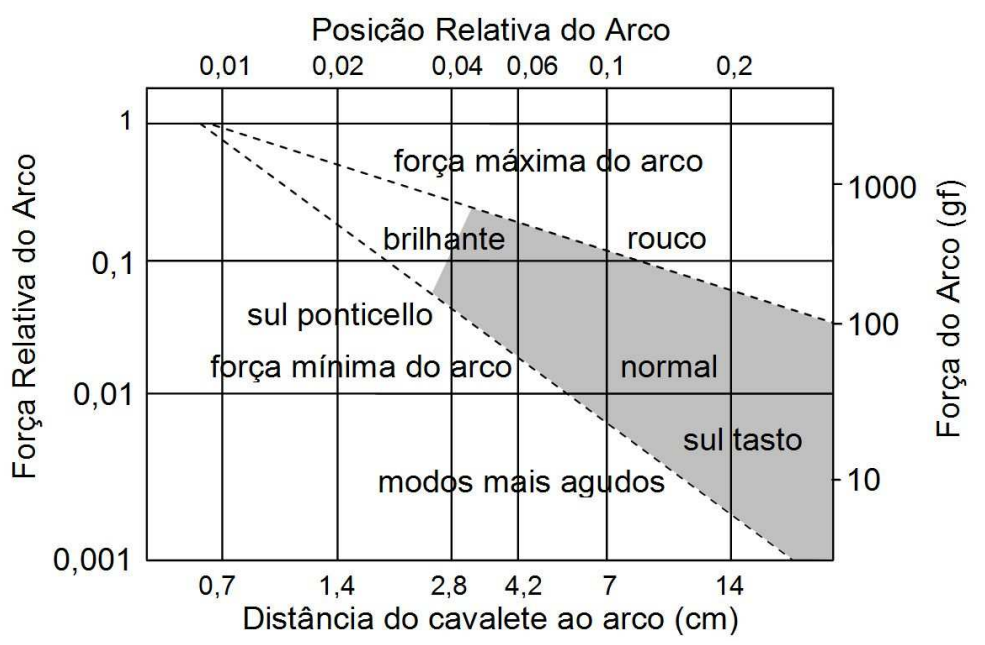

Figura 18 - Força x distância.

Fonte: WOODHOUSE, 2010.

A Figura 16 mostra o alcance de uma nota normal em um instrumento de arco em uma velocidade constante; a força mínima e a máxima despendidas quando o arco está muito perto do cavalete e difere quando está longe.

É comum violinistas que passam a tocar viola procurarem aumentar a energia simplesmente pressionando mais forte o arco na corda com o braço e com a mão direita, e geralmente levantam o ombro para fazer uma alavanca. O resultado é que o limite mais alto de força permitida no arco é excedido e o som torna-se áspero.

Karen Tuttle (1920-2010) ${ }^{73}$ apóia a utilização do uso do peso natural do braço, o contrário da pressão muscular para baixo para auxiliar os violistas a relaxar seus músculos peitorais e encontrar a liberdade no ombro. Em nossa opinião, essa é a melhor maneira para colocar pressão no arco, pois, além de produzir um som mais encorpado e com mais foco, evita problemas ortopédicos causados pela tensão.

O movimento vertical exagerado pode resultar em uma força exagerada para baixo e, consequentemente, em um som áspero, enquanto o movimento horizontal exagerado pode resultar na força insuficiente do arco, resultando em um som superficial, como visto na Figura 18.

O equilíbrio é atingido através da utilização de um movimento pendular ${ }^{74}$ do braço, que exige que o braço esteja relaxado e livre, utilizando a gravidade para gerar energia com seu peso natural. Esse movimento pendular não somente auxilia

\footnotetext{
${ }^{73}$ Professora de viola americana, desenvolveu a técnica denominada "Coordination", que enfatiza o conforto ao tocar o instrumento.

${ }^{74}$ Movimento executado com o braço pendente, oscilando sob a ação da gravidade.
} 
na geração de um som profundo, ressonante e focado, como também na clareza dos ataques curtos.

Outra consideração importante é o modo como o peso do arco é mantido quando chega na ponta em uma arcada para baixo ${ }^{75}$ para sustentar o som. ${ }^{76} \mathrm{O}$ golpe de arco, com seu movimento pendular, dá origem a essa questão, já que a forma pendular do braço imita a curva natural do arco. Presumindo que a mão esteja no mesmo plano que o pulso e que o cotovelo, a mão naturalmente fará um movimento de pronação ${ }^{77}$ na ponta do arco. Essa pronação resulta na adição de peso através do primeiro dedo (indicador) na vareta e compensa a perda de peso do braço e do talão.

\footnotetext{
${ }_{75}^{75}$ Movimento do arco quando em direção à ponta.

${ }^{76}$ Quando o arco chega na ponta, existe menos peso do talão e do braço para gerar energia.

77 Pronação é o movimento de pressionar o dedo indicador no arco (rodar o antebraço para o lado esquerdo gerando pressão no dedo indicador), aliviando a pressão exercida pelo dedo mínimo (mindinho). Este movimento acarretará uma maior intensidade do som. Supinação é o movimento de pressionar o dedo mínimo no arco (rodar o antebraço para o lado direito) aliviando a pressão do dedo indicador, fazendo com que o som seja menos intenso.
} 

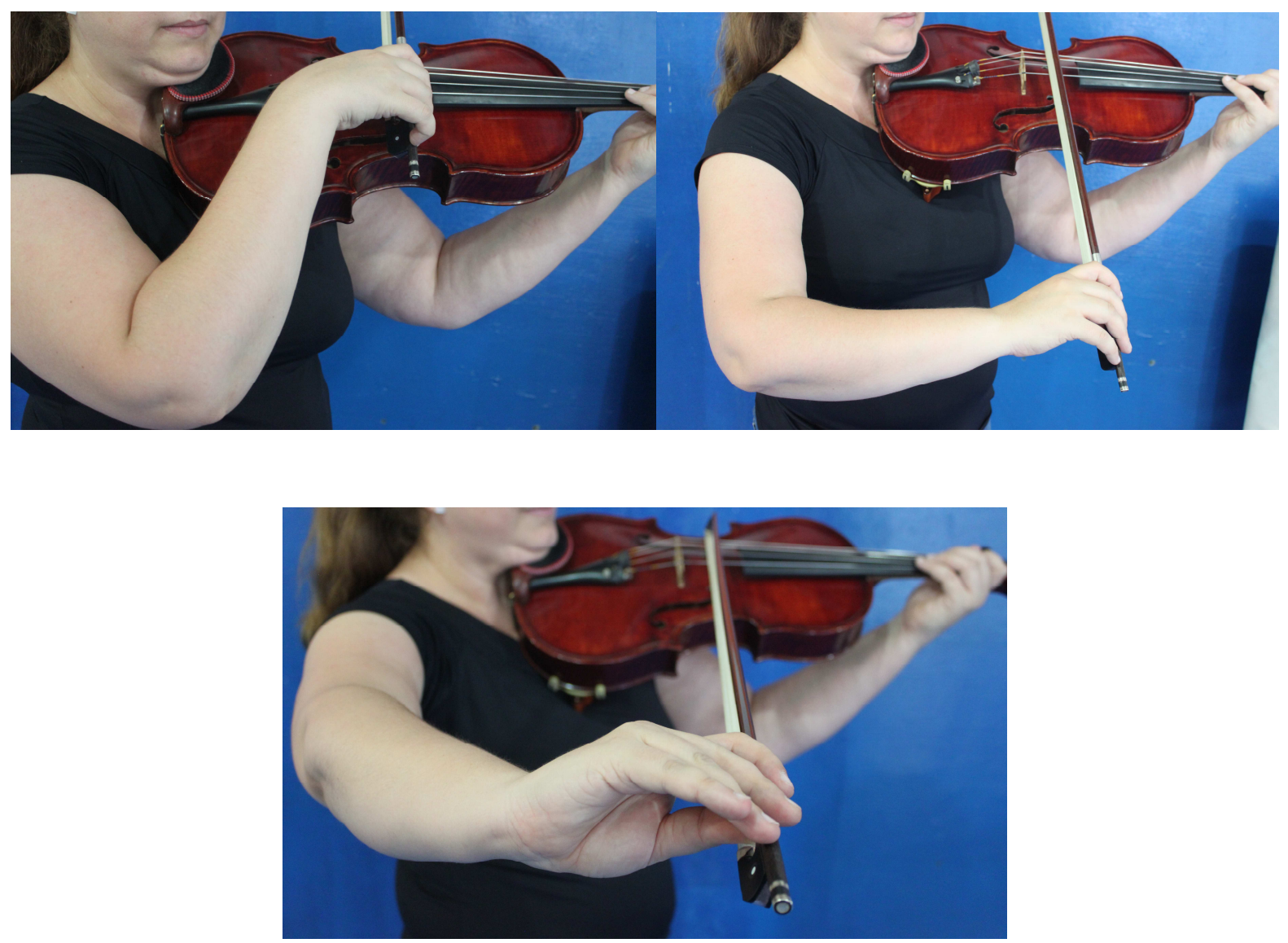

Figura 18 - Posições da mão direita no talão, meio e ponta do arco.

Fonte: Imagens captadas pela autora.

Karen Tuttle desenvolveu outro método pelo qual é possível ao violista manter e até aumentar a energia transmitida na ponta do arco. Ela denomina "repull" e descreve:

Iniciando no talão com arco para baixo, quando se aproxima da ponta, o ponto de equilíbrio é deslocado através da mão. Quando se sente o primeiro dedo fazendo a pressão primordial, você sente a arrancada através das articulações do quarto dedo e então os dedos pressionam em direção à ponta... o "repull" dá uma energia extra na ponta (DANE, 2002, p. 31). ${ }^{78}$

Por esse método, o cotovelo e o ombro relaxam logo após o ponto de equilíbrio ser encontrado no arco para baixo e a pronação da mão e do pulso permite reequilíbrio da mão. A extensão dos dedos perto da ponta faz aumentar a

\footnotetext{
78 "As you approach the tip, the balance shifts trough the hand. When you feel the first finger taking Paramount pressure, you feel the pull across the knuckles towards the fourth finger and then the fingers straighten out towards the tip"
} 
energia adicional colocada. O resultado é um som rico, cheio e expressivo na ponta do arco.

\subsection{Distribuição e Velocidade do Arco na Corda}

Os violistas tocam numa região do arco mais próxima ao talão do que os violinistas. Tocar mais perto do talão é um modo mais simples de aumentar a quantidade de energia na corda, já que o arco é naturalmente mais pesado perto do talão e é muito mais fácil utilizar o peso do braço.

A distribuição de arco que favorece a metade inferior ${ }^{79}$ deste é uma posição mais natural para o violista. Uma posição confortável para o braço do arco é quando está flexionado aproximadamente 90 graus.

Por causa do tamanho maior da viola, o braço do arco do violista fica mais longe do corpo que o do violinista e, ao utilizar uma distribuição de arco que favorece a metade inferior do arco, o violista encontra uma posição mais confortável para tocar.

A utilização de um golpe de arco mais lento enquanto mantém um peso constante também aumenta a energia do arco, já que a energia criada pela velocidade do arco é concentrada essencialmente em uma área menor.

Para se produzir uma boa sonoridade na quarta corda do violino é necessária uma combinação de peso de arco com menor velocidade de sua condução, o que contribui para produzir um som com mais foco. Portanto, podemos considerar que este mesmo princípio pode ser aplicado na viola, em comparação com a produção do som no violino.

Esta tarefa será mais fácil com o emprego de um pequeno ataque com o arco na corda, uma vez que o arco da viola é cerca de 10 gramas mais pesado se comparado ao do violino. Este peso certamente auxilia na execução e facilita o controle dos golpes de arco.

\footnotetext{
${ }^{79}$ Parte do arco entre o talão e o meio.
} 


\subsection{Ataque e Relaxamento}

Os princípios da utilização do arco para fazer a corda vibrar são os mesmos para todos os golpes de arco. Alguns golpes de arco fazem a corda vibrar mais que outros. Golpes de arco cujos ataques são iniciados com o arco na corda, como o legato e o detaché, fazem com que a corda vibre em seu potencial máximo, enquanto golpes de arco cujos ataques começam com o arco no ar, "fora da corda", como o spiccatto e o ricochet são mais percussivos por natureza. Todo golpe de arco tem um componente vertical e um horizontal e suas proporções respectivas variam para criar seus resultados particulares.

As características naturais do arco auxiliam na execução dos golpes de arco cujos ataques se iniciam "de fora da corda", pois a tensão entre a vareta e a crina do arco e a curva côncava natural da vareta do arco criam elasticidade no arco, e ao arco naturalmente salta se deixado cair sobre a corda.

Os golpes de arco cujos ataques permanecem "na corda" exigem que o peso do braço seja constante, principalmente no movimento horizontal, para que impeça que a elasticidade do arco atue fazendo o arco sair da corda. Tirar peso do braço e adicionar movimento vertical fará com que o arco salte na corda.

Segundo Galamian (1962, p. 64), o spiccatto é um golpe de arco no qual o arco salta da corda durante a troca de direção em cada nota. $O$ arco pode saltar de diversas maneiras, desde com a contribuição deliberada do violinista para que o salto ocorra, até o "molejo" do arco trabalhando por si mesmo. Tradicionalmente, o spiccatto se refere ao arco sendo jogado deliberadamente em direção à corda em cada nota.

O componente horizontal do spiccatto é o detaché. É um golpe de arco efetuado com o antebraço, normalmente executado perto da metade do arco, produzido pela abertura e fechamento do cotovelo nas arcadas para baixo e para cima, respectivamente. O spiccatto combina uma queda vertical do antebraço, mão e arco em conjunto, em cada nota, ao detaché.

$\mathrm{O}$ arco começa acima da corda e o antebraço cria um movimento de queda para cada nota. A elasticidade natural do arco, da corda e dos dedos faz com que haja um rebote da corda após cada movimento, permitindo que o arco seja jogado novamente na nota seguinte. 
A prática dos movimentos horizontais e verticais dos componentes do spiccatto separadamente é útil para a compreensão do funcionamento do braço direito. Como mencionado acima, o componente horizontal é um simples detaché. Praticar uma passagem em spiccatto utilizando o detaché forçará a abertura e o fechamento do cotovelo, que é necessário para esse golpe de arco, e auxiliará nas mudanças de cordas.

O componente vertical do spiccatto é a queda do antebraço, mão e arco em conjunto, e deve ser praticado em cada nota. A qualidade de som do componente vertical por si só é quase percussivo, mas será melhorado quando combinado com o componente horizontal.

$\mathrm{O}$ antebraço, mão e arco devem mover-se em conjunto na forma de um $\mathrm{U}$, iniciando acima da corda e caindo contra ela, fazendo contato com a corda na parte mais baixa do $\mathrm{U}$, e voltando à sua altura original. Ao praticar o componente vertical do spiccatto, o contato deve ser feito no mesmo lugar do arco para cada arco para cima e para baixo.

Quando o componente horizontal e o vertical forem controlados separadamente, devem ser combinados. Uma maneira de combiná-los é repetir uma pequena passagem, começando devagar, tocando primeiramente o componente horizontal, seguido pelo vertical, alternando.

Sugere-se aumentar a velocidade após ambos serem tocados, repetindo este processo quantas vezes for necessário, até chegar na velocidade desejada para o golpe do arco. Conforme a velocidade vai aumentando, os componentes vertical e horizontal vão se juntando, até que se tornem um só.

O sautillé, assim como spiccatto, é um detaché "fora da corda". Difere do spiccatto pelo fato de que não é efetuado com a energia do movimento do arco, mas sim com a elasticidade do arco para fazê-lo saltar. O arco saltará como resultado de suas características se o instrumentista redistribuir o peso do braço.

A utilização do peso do braço durante o detaché evita que o arco salte, a redistribuição do peso do braço para deixar a mão mais leve durante o sautillé, para que $o$ arco pule da corda. Esse golpe de arco pode ser praticado iniciando pelo detaché, aumentando a velocidade, utilizando cada vez menos arco e deixando a mão e o pulso mais leves, até que o arco comece a saltar. É importante ressaltar que cada arco tem um local onde esse golpe ocorre mais naturalmente, já que o peso e a elasticidade são diferentes em todos arcos. 
O ricochet é um dos golpes de arco mais percussivos. Como o próprio nome diz, consiste no arco batendo na corda e saltando de volta. Como todos os golpes "de fora da corda", as características naturais do arco fazem com que ele salte da corda. O ricochet salta diversas vezes na mesma direção, cada salto é um rebote do contato inicial com a corda. É mais frequentemente executado com um arco para baixo, e algumas vezes finalizado com a última nota para cima.

Assim como o spiccatto, é útil identificar os componentes vertical e horizontal do ricochet. Quando praticados separadamente, o componente horizontal é um golpe de arco muito pesado, ligando as notas do ricochet na corda. É extremamente compacto, utilizando literalmente um centímetro de arco e o peso total do braço do instrumentista, criando uma sensação de ter o arco colado na corda.

O componente vertical é o mesmo que o do spiccatto, jogando o antebraço, a mão e o arco em conjunto na corda. As quedas repetidas são na mesma direção, normalmente com o arco para baixo, ao invés de alternar arcos para baixo e para cima como no spiccatto.

O componente horizontal e o vertical podem ser combinados como no spiccatto, praticando o componente horizontal e o vertical separada e alternadamente, iniciando lento e aumentando a velocidade. Na velocidade normal, deve haver somente um gesto vertical para o ricochet, na primeira nota. Mas, numa velocidade mais lenta, o gesto deve ser efetuado a cada nota.

A prática com um gesto vertical em cada nota auxilia a mão a ter a sensação do arco saltando, que ajudará no controle do número final de saltos quando houver apenas um movimento. À medida que a repetição torna-se mais rápida e 0 componente horizontal e o vertical se juntam, o componente horizontal deve prevalecer, exceto pelo movimento vertical que dá início ao golpe de arco, e a mão deve permanecer sensível à articulação de cada nota.

O martellé é um golpe de arco articulado originado do detaché. Literalmente significa "martelar" e cada golpe tem sua articulação própria. O golpe inicia de uma posição de relaxamento com o peso do braço assentado no arco. Após tocar a corda, o antebraço puxa o arco como se fosse um detaché rápido. Um pouco do peso do braço é colocado no momento em que o arco é puxado, diminuindo a pressão e separando a vareta do arco e a crina. Enquanto o movimento do braço direito é similar ao movimento que é feito para o detaché, os dedos ficam mais firmes no martellé e, ao movimentar o arco na corda, antecipam o movimento do 
pulso ao invés de segui-lo. O golpe com peso do braço e com o dedo deve ser reiniciado em cada nota.

O staccato para cima e para baixo consiste essencialmente em pequenos martellés repetidos que continuam em uma direção. Cada nota deve iniciar de uma posição relaxada, com o peso do braço no arco, fazendo com que a vareta do arco envergue devido ao peso do braço, exercendo mais pressão sobre a corda. $O$ cotovelo contribui para que o golpe de arco seja similar ao martellé, puxando o antebraço para dentro para o staccato para cima e para fora, para o staccato para baixo, fazendo com que o arco se mova horizontalmente em ambas as direções. $O$ peso do braço deve ser colocado no movimento deste, deixando a vareta do arco longe da crina, mas deve ser reiniciado em cada nota. Mesmo que o arco se mova na mesma direção nas notas subsequentes, é importante que cada nota tenha o ataque próprio.

Os acordes podem ser realizados de diversas maneiras com o arco, tocando todas as notas ao mesmo tempo, até tocando as notas duas a duas, ou mesmo nota a nota como num arpejo. Os violinistas e violistas devem ser versáteis para tocar os acordes de todas as maneiras e não se restringir às limitações observadas nos instrumentos.

É difícil tocar todas as notas de um acorde de três notas de uma vez, mas não é impossível, devido à curvatura do cavalete e à tensão das cordas. É fundamental a compreensão do funcionamento do instrumento e do arco e dos procedimentos necessários para se tocar simultaneamente as cordas múltiplas com 0 arco.

Os princípios da produção de som simultâneos em cordas múltiplas são os mesmos da produção de som em uma corda de cada vez. Para fazer com que a corda vibre, o arco deve encostar na corda e ser puxado perpendicular a ela. Pelo fato de cada corda ter uma espessura distinta e uma rota própria na qual o arco passa, é essencial identificar a quantidade de peso do arco a ser utilizado, identificar os pontos de contato apropriados e escolher uma rota para o arco para que a execução desses acordes seja bem sucedida.

Para tocar todas as cordas do acorde de uma vez sem ondulações ou quebras no acorde, o arco deve mover-se em um ângulo apenas. Um ângulo médio da combinação das cordas é o apropriado para fazer soar todas as cordas. Para um acorde de três notas, o ângulo da corda central é utilizado. 
Apenas o posicionamento apropriado do arco não é suficiente para criar o contato com todas as cordas no acorde. A curvatura do cavalete faz com que seja necessário que algumas cordas sejam pressionadas significantemente para que fiquem no mesmo plano.

A utilização do peso do braço e a escolha do ponto de contato são fundamentais para que isso possa ser executado. A tensão das cordas é maior perto do cavalete e menor próximo ao espelho, portanto a escolha do ponto de contato mais perto do espelho facilitará a pressão nas cordas pelo peso do braço, colocando-as no mesmo ângulo.

Além da escolha do ponto de contato perto do cavalete, cada corda tem um ponto de contato ideal diferenciado devido à sua espessura, sendo que as cordas graves soam melhor mais perto do espelho e as agudas mais perto do cavalete. Para a obtenção de uma melhor sonoridade de todas as cordas, entretanto, é necessário que o ângulo do arco seja levemente modificado, com a ponta do arco mais distante do cavalete do que o talão.

Os acordes de três e os de quatro notas exigem uma quantidade significativa de peso do braço para pressionar as cordas com o arco, tornando possível alcançar todas elas e fazê-las vibrar. Os dedos da mão direita absorvem o impacto, amortecendo o ponto de contato das cordas, permitindo que as cordas vibrem quando o arco é puxado. Os dedos seguem o movimento do arco, reagindo à resistência que faz as cordas vibrarem.

Esses acordes são mais comumente tocados com o arco para baixo, mas os princípios são os mesmos para tocá-los com o arco para cima. É um pouco mais difícil realizar acordes com arcada para cima.

O movimento de empurrar a mão numa arcada para cima também exige mais esforço do que puxar o arco para baixo com o cotovelo. É perfeitamente possível tocar esses acordes com o arco para cima, se todos os princípios descritos acima forem utilizados.

Os acordes de três notas frequentemente aparecem em uma sucessão de arcadas para baixo tocadas repetidamente. É melhor tocar esses acordes com o arco em movimentos circulares. $O$ ataque desses acordes deve ser proveniente de movimento circular, terminando na forma de um $U$ para que o som seja atacado e as cordas continuem a vibrar. Esse golpe de arco deve ser realizado na metade inferior do arco, o cotovelo deve abrir o ângulo do braço e antebraço no arco para baixo e 
fechar no arco para cima, similarmente ao detaché, mantendo o movimento do arco paralelo ao cavalete.

O movimento de levar o arco para o talão com preparação para o acorde seguinte deve ser incluído no ataque do acorde inicial. Quando isso puder ser feito ao completar a forma de um círculo com o arco, a retomada do arco com menos curva é mais eficiente. A forma circular reflete mais acuradamente o movimento mais econômico de tocar o acorde e retomar o arco.

Para acordes em sucessão rápida, os instrumentistas frequentemente aceleram o gesto inteiro, incluindo o movimento de retomada do arco, entretanto isso faz com que os acordes soem curtos. A retomada pode ser rápida, sem comprometer o som dos acordes. Para controlar a coordenação de uma retomada rápida, os movimentos devem ser praticados com velocidades exageradas, tocando o acorde com a velocidade do arco mais lenta possível e voltar ao talão o mais rápido possível. É necessário um tempo extra antes de cada acorde subsequente para o assentamento e preparação para o acorde seguinte.

$\mathrm{Na}$ viola, os acordes devem ser executados com mais pressão e velocidade de arco que no violino, e iniciados "da corda". Os acordes de três notas também são de mais difícil execução na viola, pois a distância e o ângulo entre as cordas é maior.

Notas curtas como o collé e o spicatto no violino são freqüentemente atacadas de cima, do ar, com um ataque "batido" (GALAMIAN, 1966, p. 73-77). Por causa do ataque mais lento da viola e da queda do tempo, assim como sua exigência de mais energia para iniciar a vibração, é crítico que o violista aprenda a começar os ataques das notas curtas da corda e permita um rápido relaxamento para manter a clareza.

Ataques "do ar" em notas rápidas e curtas frequentemente não têm peso suficiente para dar energia suficiente para fazer a corda soar com clareza. Ao começar o ataque da corda, o arco tem tempo e peso para ativar a corda e o rápido relaxamento permite um enfraquecimento apropriado antes de a próxima nota começar. Até mesmo em passagens que utilizam o spiccatto, nas quais o arco é jogado na corda e levantado (em passagens mais lentas) ou rebotes (passagens mais rápidas), é possível fazer a vareta do arco da viola saltar sem tirar a crina da corda. O ataque inicial do spiccatto na viola deve sair "da corda" e os golpes subsequentes "do ar", embora quase sem perder o contato com a corda. 
Em resumo, golpes de arco como collé e spicato devem ser tocados mais como um martellé (começando da corda com um "beliscão"), levando em consideração os ajustes de distribuição, velocidade e peso do arco.

\subsection{Ajustes Técnicos}

A maioria das exigências para o violista é a mesma para o violinista. A maneira de segurar o arco e os movimentos da mão e do braço é equivalente para ambos. A viola é um instrumento maior que o violino, portanto, deve-se enfatizar as diferenças na maneira de tocar.

Os violistas enfrentam o problema ao tentar produzir um som com mais volume. Tocar mais forte para tocar um instrumento maior não é a resposta. A maneira de segurar o arco deve ser firme, flexível, e os dedos devem envolver o arco mais completamente (DALTON, 1988, p. 175-176). O peso sobre o arco é imperativo para produzir um som apropriado na viola. O som produzido pelo peso, e não pela força, acontece quando o nível do braço é mais alto que o do arco.

Segundo Kubala (2004), a caixa de ressonância da viola não corresponde à freqüência da vibração das cordas, diferentemente da do violino, que é proporcional, por isso a emissão de som é mais difícil, o que exige uma técnica de arco específica, como a condução do arco dando ênfase ao uso constante de peso do braço e antebraço, ou seja, tocar "dentro da corda", o que possibilita a execução de diversos golpes de arco, além da produção de um som rico em harmônicos e em maior volume. Se tocada com uma técnica de mão direita do violino, o resultado sonoro da viola pode ser um som pobre e sem corpo.

Para que a emissão de som na viola seja semelhante ao violino, seria necessário que a caixa de ressonância do instrumento tivesse em média $10 \mathrm{~cm}$ a mais do que a média dos instrumentos utilizados pelos violistas, o que inviabilizaria a execução da mão esquerda, já que o braço do instrumentista não alcançaria apropriadamente o local da digitação das notas. Além disso, a espessura e o comprimento das cordas são maiores que os do violino, o que torna a resposta sonora mais lenta, principalmente nas cordas graves. Por isso, há a necessidade de tocar com mais pressão, menos velocidade e em região mais próxima ao talão para 
a realização de alguns golpes de arco, principalmente nas cordas mais graves (KUBALA, 2004 p. 53,54).

William Primrose (apud Dalton 1988, p. 62) diz que "[...] é impossível tocar viola e fazer força". Assim como no violino, o arco do violista deve ser segurado de maneira firme, porém relaxada, natural, com dedos e polegar dobrados. O nível de altura do braço, pulso e mão não devem estar acima do nível da vareta do arco. Deixar as articulações da mão mais altas irá fortalecer os dedos e diminuir a flexibilidade.

Reiterando a importância de uma maneira cautelosa de segurar o arco, Primrose sugere que o início do golpe de arco com um "pequeno ataque" saindo da corda, mesmo quando tocando em piano. Deve-se pensar no som antes de tocar. Defendendo a utilização de toda a crina do arco, ele diz que um violista deve convergir peso adicional "no lado" do arco para permitir que as cordas sejam tocadas mais livremente.

Henry Barrett (1978) sugere a permissão para que os músculos maiores ${ }^{80}$ do braço gerem energia. O violista perderá som se houver muita variação na posição da mão. Ele alerta que é particularmente importante manter as articulações planas e o pulso na horizontal quando no talão (BARRETT, 1978, p.70).

\footnotetext{
${ }^{80}$ Tríceps braquial, Bíceps braquial, Serrátil anterior, Flexor superficial dos dedos, Flexor profundo dos dedos.
} 


\section{Capítulo 2 - Execução no que concerne à mão esquerda}

Assim como em relação à mão direita, existem diversos aspectos a ser tratados concernentes à mão esquerda.

\subsection{Vibrato}

Na época de Geminiani, o uso do vibrato foi detalhadamente examinado. Enquanto muitos acreditam que o vibrato foi utilizado apenas de forma reduzida como meio de expressão nos séculos dezesseis, dezoito e dezenove, pois Leopold Mozart (1951, p. 203) recomenda em seu tratado que o vibrato não seja utilizado exageradamente, o tratado de Geminiani de 1751 faz referência ao uso contínuo do vibrato, criando, assim, muitas polêmicas em torno do assunto (GEMINIANI, 1951, p.8).

Na segunda metade do século XX o vibrato passou a ser utilizado também como efeito, por compositores como Penderecki, Schnittke e Takemitsu. É utilizado para expressão e cor do som produzido pelo instrumento.

O vibrato consiste em um mecanismo que modifica levemente a afinação. $A$ habilidade para fazer um bom vibrato envolve a compreensão do mecanismo, além da consciência de quando e como utilizá-lo. O ideal é que o instrumentista seja consciente sobre a forma de realizar o vibrato.

O vibrato pode ser utilizado para modificar a intensidade do som além de colori-lo. Para ambos os efeitos é necessária habilidade de tocar diferentes tipos de vibrato, variando sua velocidade e amplitude.

Segundo Galamian (1962, p.37) Os três tipos fundamentais de vibrato utilizados no violino e na viola são o de braço, de pulso e de dedo, denominados de acordo com a parte do corpo que inicia o movimento. Independentemente do tipo de vibrato a ser utilizado, a articulação mais próxima da unha basicamente determina sua qualidade.

Se essa articulação é afrouxada, a ponta do dedo será afetada pelo mecanismo de vibração, alterando a afinação da nota. Se a articulação estiver rígida, nenhuma quantidade de vibração do braço, mão ou dedo farão com que a ponta do dedo altere a afinação e nenhum vibrato será ouvido. 
O mecanismo do vibrato faz com que o dedo se mova repetidas vezes para baixo de sua afinação original e volte. Quanto maior for o movimento do vibrato, mais fácil é a criação de um vibrato mais amplo e lento; quanto menor o movimento, mais fácil a criação de um vibrato mais estreito e rápido. Há um grande número de combinações de velocidades e extensões que constituem o vibrato. $O$ ideal é se ter a habilidade de utilizar todos os mecanismos e utilizá-los de acordo com o que a obra pede.

O mecanismo de vibrato de braço consiste no antebraço, pulso e mão em conjunto, movendo como o mecanismo de mudança de posição, mas sem a mudança real de posição. $\mathrm{O}$ antebraço se move em direção à voluta retorna à sua posição original com o cotovelo atuando como uma dobradiça, enquanto os dedos mantém sua posição no instrumento. Como resultado do movimento do antebraço, os dedos se alongam e retornam à posição original, movendo a ponta do dedo para baixar a afinação e retornando à posição original. (GALAMIAN, 1962, p.37)

O mecanismo do vibrato de pulso consiste no movimento da mão utilizando o pulso, como uma dobradiça. Similarmente ao vibrato de braço, a mão se move em direção é voluta e retorna à sua posição original, enquanto os dedos mantém sua posição no instrumento. O dedo também se alonga e retorna à sua posição original como resultado do movimento, com a ponta do dedo baixando a afinação e retornando à posição original. (GALAMIAN, 1962, p.37)

O mecanismo do vibrato de dedo é tão pequeno que o dedo não alonga e a ponta do dedo não se movimenta. Ao invés disso, o dedo pulsa para cima e pra baixo na nota. Esse mecanismo consiste em um leve levantamento e colocação do dedo da articulação base da mão, modificando a pressão na ponta do dedo sem efetivamente tirá-la da corda.

A variação da pressão da ponta do dedo modifica a área da superfície da ponta do dedo que está em contato com a corda, alterando levemente a afinação da nota. Com mais pressão, mais a ponta do dedo recobre a corda, subindo a afinação; quanto menos pressão, uma área menor da ponta do dedo recobre a corda, baixando a afinação. A diferença entre a localização da maior área e a da menor área que a ponta do dedo interrompe a vibração da corda é o tamanho da variação da afinação com o vibrato de dedo. (GALAMIAN, 1962, p.37)

O vibrato é um dos aspectos técnicos que apresentam mais diferenças de mão esquerda entre o violino e a viola. Pelo fato de o espaçamento entre os dedos 
ser maior por causa do comprimento maior da corda, o violista necessita ter um vibrato mais longo para que as oscilações sejam audíveis. Se o vibrato for muito estreito, pode não ser ouvido.

Para o desenvolvimento de um vibrato mais largo, White Smith defende que deve-se tocar com a parte mais polpuda na parte de trás do dedo (WHITE-SMITH, 2000, p.59). Isso aumenta a área coberta pelo dedo, permitindo com que a área oscilante aumente também. Esse ângulo mais horizontal é importante para a posição da mão esquerda. Entretanto, White-Smith alerta que apesar de mais longo, o vibrato da viola não é necessariamente mais lento (WHITE-SMITH, 2000, p.59). É muito comum a associação do vibrato mais largo com velocidade lenta. A solução é totalmente relacionada com a consciência, e especialmente, com o caráter do som. O violista deve desenvolver uma grande variedade de velocidades e amplitudes de vibrato e encontrar a combinação correta que harmonize com o caráter desejado do som.

\subsection{Dedilhado e Mudança de Posição}

O ângulo mais horizontal do dedo auxilia a alongar o vibrato e também permite que a mão se abra mais, gerando um alcance maior entre os dedos. $O$ aumento da distância entre as notas no espelho é outra preocupação dos violinistas que passam a tocar viola, e o ângulo mais horizontal ajuda a resolver esse problema.

Esse ajuste pode exigir algumas modificações na mão esquerda, principalmente no ângulo do pulso. Um ângulo mais horizontal do pulso que o utilizado no violino auxilia para que os dedos fiquem também num ângulo mais horizontal, sem aumentar a tensão do antebraço ou tensionar o pulso. 


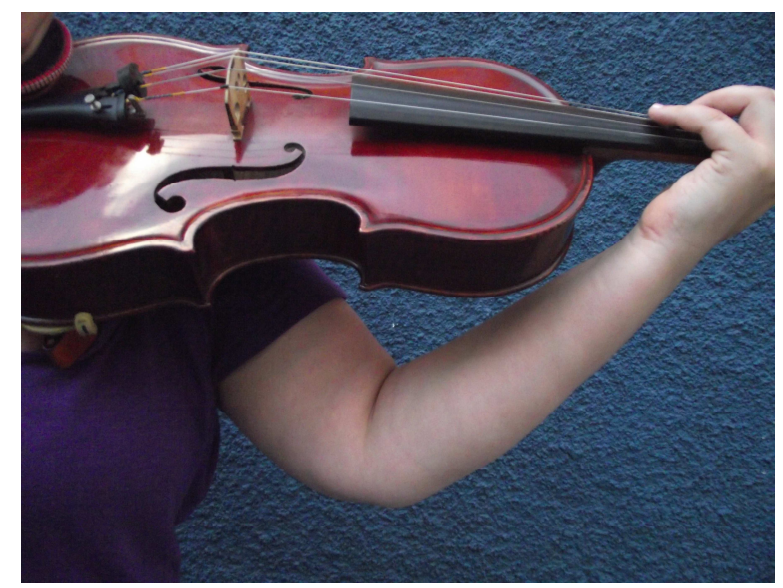

Figura 20 - Viola

Fonte: Imagem captada pela autora.

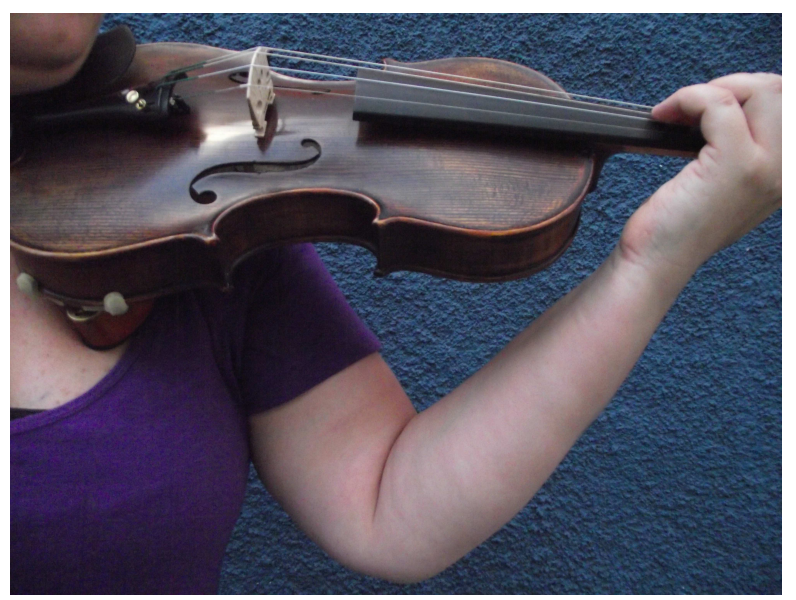

Figura 21 - Violino

Fonte: Imagem captada pela autora.

Alguns estudantes procuram chegar num ângulo mais horizontal dos dedos estendendo o pulso para fora. Mas, embora este seja alcançado, isso faz com que a distância dos dedos diminua e com isso seja aplicada tensão desnecessária na mão, pulso e antebraço.

Além disso, o tamanho do instrumento já exige que o braço do violista se estenda mais que o do violinista, o que naturalmente aumenta o ângulo entre o braço e o antebraço, tendo o cotovelo como vértice, o que faz com que o pulso se posicione mais horizontalmente, e, consequentemente, os dedos também (Figuras 20 e 21).

Primrose (1988) considera os dedilhados específicos da viola umas das diferenças mais críticas entre esta e o violino. "Desde que consigo me lembrar, dedilhar a viola como se fosse análoga ao violino tem sido a queda da maioria dos 
violistas, e o erro ainda persiste. ${ }^{81}$ Entender essa distinção foi fundamental para ele dizer "as sonoridades e as belezas da viola como um instrumento distinto do violino" (DALTON, 1988, p. 114-116).

Algumas considerações sobre os dedilhados da viola são práticas. O espaço maior entre as notas significa que, para quem tem mãos de pequenas a médias, os dedilhados com extensão não podem ser utilizados tão frequentemente quanto no violino. Entretanto, é possível tocar por longos períodos ${ }^{82}$ na meia posição, o que no violino é mais difícil, devido ao pequeno espaço existente entre a pestana e a primeira posição. A segunda posição é também muito utilizada na viola por longos períodos.

A maioria das considerações sobre o dedilhado, entretanto, refletem preocupações sobre caráter e foco do som. Primrose (DALTON, 1988) defendia a utilização de cordas soltas, posições baixas e mudanças de corda com o objetivo de atingir um caráter de som enquanto intensifica o foco e o brilho, especialmente nas cordas mais graves (DALTON, 1988, p. 114). Observamos que os violistas utilizam este tipo de dedilhado, o que difere, no geral, das escolhas realizadas por violinistas, que frequentemente optam por usar mais cordas presas e posições mais altas.

Existem vários aspectos a considerar ao selecionar os dedilhados, como fatores históricos e práticos e a sonoridade individual de instrumentos diferentes. - é difícil recomendar a um violista que escolha exclusivamente dedilhados nas posições mais baixas e cordas soltas. Entretanto, pelo fato de essas escolhas frequentemente intensificarem a qualidade e a clareza do som, é de suma importância que o estudante as explore e experimente se poderiam ser apropriadas para o contexto musical.

\subsection{Scordatura}

"É um termo aplicado a instrumentos de cordas para designar uma afinação que não a normal. [...] Oferece novas cores, timbres e sonoridades e possibilidades harmônicas alternativas e, em alguns casos, o aumento da tessitura de um instrumento. Também poderia auxiliar na imitação de outros instrumentos e facilitar a execução de composições completas ou tornar

\footnotetext{
81 "Almost for longer that I care to remember, I have held that to finger the viola as an analogue to the violin has been the downfall of most violists, and the fault persists to this day"

${ }^{82}$ Utilizando o dedilhado fixo nesta posição em passagens longas.
} 
possíveis diversas passagens com intervalos, mudanças de cordas intrincadas ou cordas duplas não convencionais." ${ }^{83}$

A tradução literal do termo italiano é "desafinado". É um recurso utilizado para alterar a sonoridade de um instrumento, modificando a tensão de uma ou mais cordas, facilitar a execução de certos tipos de passagens, como as passagens rápidas em cordas duplas em diversos intervalos e composições completas em tonalidades mais complicadas, grandes intervalos, e/ou aumentar a extensão do instrumento ao abaixar a corda mais grave, o que muitas vezes pode proporcionar um pedal para os acordes. Também permite a execução de notas, sequências ou combinações de notas que seriam impossíveis sem essa técnica.

O conceito de alteração da afinação do violino (normalmente em favor da tonalidade da composição que seria tocada) era comum nos primeiros estágios do desenvolvimento do instrumento. Entretanto, nenhum tipo de afinação substituiu permanentemente as quintas normais do violino (RUSSEL, 1938, p. 84).

A afinação de cada composição, quando indicada, ocorre no início, normalmente à esquerda do primeiro pentagrama. A tonalidade, entretanto, é baseada na accordatura. ${ }^{84}$

XI.

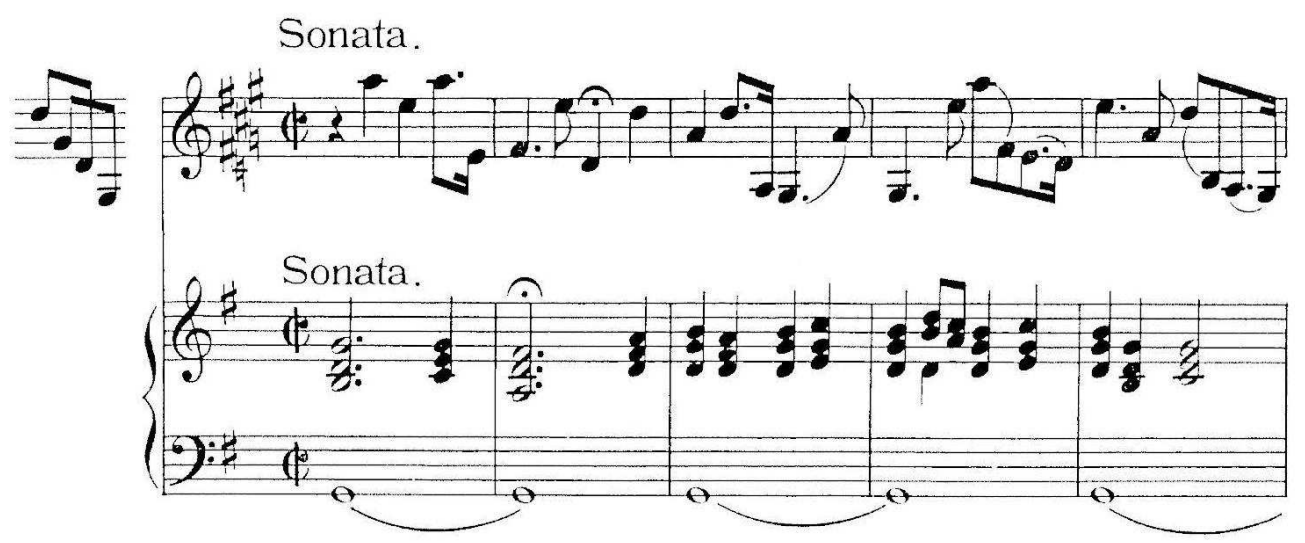

\footnotetext{
83 "A term applied largely to lutes, guitars, viols and the violin family to designate a tuning other than the normal, established one... It offered novel colours, timbres and sonorities, alternative harmonic possibilities and, in some cases, extension of an instrument's range. It could also assist in imitating other instruments, and facilitate the execution of whole compositions or make possible various passages involving wide intervals, intricate string crossing or unconventional double stopping." http://www.oxfordmusiconline.com/subscriber/article/grove/music/41698?q=scordatura acessado em 18/11/2010 ${ }^{84}$ Designação genérica para a afinação de um instrumento, geralmente utilizada para indicar que a afinação é normal.
} 
A scordatura no exemplo acima, da décima primeira Sonata Rosário, de Biber (1644-1704), tem o violino afinado em oitavas (sol, sol, ré, ré), com as cordas centrais trocadas de lugar uma com a outra, ao invés das quintas usuais (sol, ré, lá mi). Pelo fato de os violinistas não estarem acostumados a transportar à primeira vista (o que necessitaria um dedilhado completamente diferente), a scordatura é escrita de acordo com o dedilhado normal, não de acordo com a afinação original.

Para tocar na afinação apropriada e manter um padrão familiar de dedilhado, são necessários às vezes diversos acidentes na armadura de clave. A passagem no exemplo tem a armadura de clave em lá maior, mas na verdade soa em sol maior. Boyden (1980, p. 250) se refere a isso como "notação de controle da mão" ou "espécie de tablatura para um tipo de instrumento transpositor". Para fazer com que essa notação funcione, é necessário seguir algumas regras:

- A primeira posição deve ser utilizada sempre que possível;

- Deve-se utilizar cordas soltas a não ser que o contrário esteja especificadamente indicado.

- Os acidentes ocorrentes se referem somente à nota em questão, não à oitava acima ou abaixo.

Essas informações apontam para a conclusão de que a maioria das composições com scordatura são de difícil execução para qualquer violinista, mesmo os mais experientes. Uma exceção à notação "tablatura" mencionada acima é quando a corda sol tem sua afinação abaixada para o fá sustenido, mas as notas continuam escritas no som real.

Entretanto, quando a scordatura se torna complicada, esse método não é prático. O violinista normalmente possui dedilhados determinados nas primeiras três posições de cada corda. Se a afinação da corda muda, mas nenhuma transposição é utilizada, torna-se necessário estruturar um novo padrão de dedilhado, dificultando a execução.

Algumas scordaturas que aumentam ou baixam significantemente as afinações fazem com que seja necessária a troca de cordas no violino moderno (por exemplo, a troca da corda ré pela corda lá). Isso ocorre porque, devido à 
constituição do materiais das cordas modernas, revestidas de prata ou alumínio, sua extensão é mais limitada.

Ao limitar a tensão, as cordas do violino moderno mantêm um nível de afinação mais consistente. No século dezessete a maioria das cordas de violino eram feitas de tripa, sem revestimento, e muitas vezes resultava num nível de afinação inconsistente entre as quatro cordas, mas permitia que fossem esticadas significantemente.

É provável que os violinistas tenham herdado a scordatura dos instrumentistas que tocavam alaúde e viola da gamba. Mais especificamente, Andreas Moser (1919) diz que a prática da scordatura utilizada pelos violinistas alemães no século dezessete e encontrada em diversas composições dessa época, resultaram da transferência do alaúde para a viola da gamba, e então para o violino.

Tanto o alaúde quanto a viola da gamba possuíam seis cordas afinadas em quartas, com um intervalo de terça no meio. A terça era ocasionalmente modificada de acordo com a necessidade da obra. Outras terças eram adicionadas também para tocar o máximo possível as terças fundamentais da obra em cordas soltas.

No período barroco, o violino era o instrumento dominante nas orquestras das cortes e o instrumento favorito dos solistas que desejavam mostrar seu virtuosismo. Muitos compositores seguiram os passos dos alaudistas e adotaram a técnica da scordatura para a família dos violinos. A gama de timbres, possibilidades harmônicas e aumento de extensão fizeram com que a scordatura fosse um artifício muito popularmente utilizado na literatura do violino nos séculos dezessete e dezoito.

A primeira obra impressa conhecida que utilizava a scordatura no violino foi a segunda sonata para violino do compositor Biago Marini, em 1629. O compositor alemão Heinrich Biber aplicou a técnica extensivamente em suas obras para violino.

Em quatorze de suas dezesseis sonatas "Rosário" para violino e baixo contínuo, ele especificou diferentes combinações de afinações para todas as quatro cordas, de acordo com as tonalidades principais de cada sonata. Ao final das quinze sonatas do conjunto, existe uma passacaglia, sem a utilização da scordatura, como mostrado abaixo. 


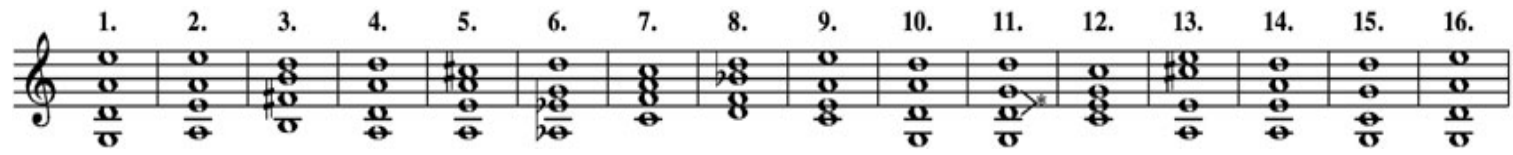

No século dezoito, a scordatura surgiu na França e Itália, e compositores como Gaspard Corrette, Antonio Vivaldi, Giuseppe Tartini e Antonio Lolli continuaram a descobrir mais efeitos especiais proporcionados por essa técnica. No século dezenove, Niccoló Paganini levou a scordatura a novos níveis em seus concertos virtuosísticos, reafinando livremente seu instrumento durante as performances para gerar novos harmônicos e cordas duplas incomuns.

No final do século dezenove, a utilização da técnica da scordatura começou a decair, embora muitos compositores do período romântico utilizassem a técnica com finalidade de efeitos expressivos.

Camile Saint-Saens utilizou em sua obra Dança Macabra a scordatura no violino solo, baixando a corda mi em meio tom, para mi bemol, para um trítono, com a finalidade de causar o efeito desse intervalo em cordas soltas.

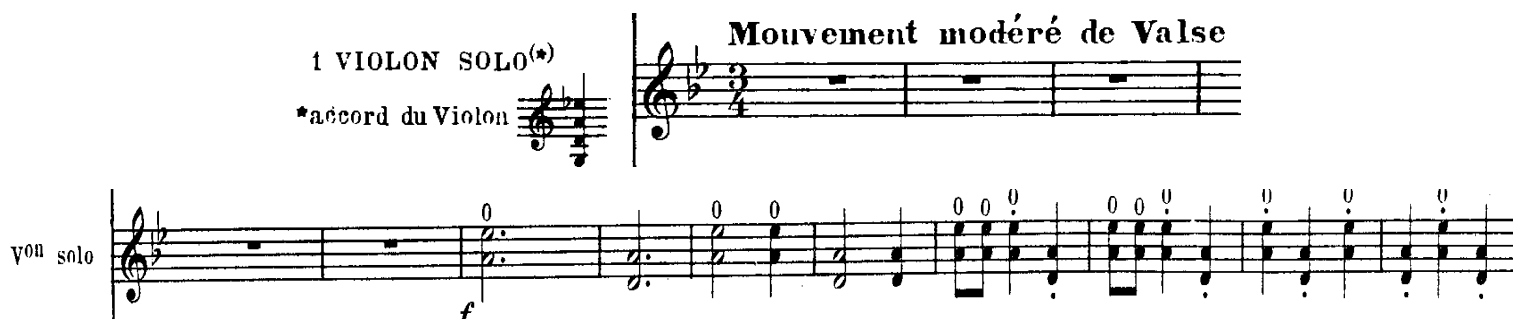

No segundo movimento de sua sinfonia n.4 em sol maior, Gustav Mahler designa uma afinação diferente para o violino solo: lá-mi-si-fá sustenido, e pede para que $o$ instrumentista entre com dois violinos no palco, um afinado um tom acima e outro com a afinação normal.

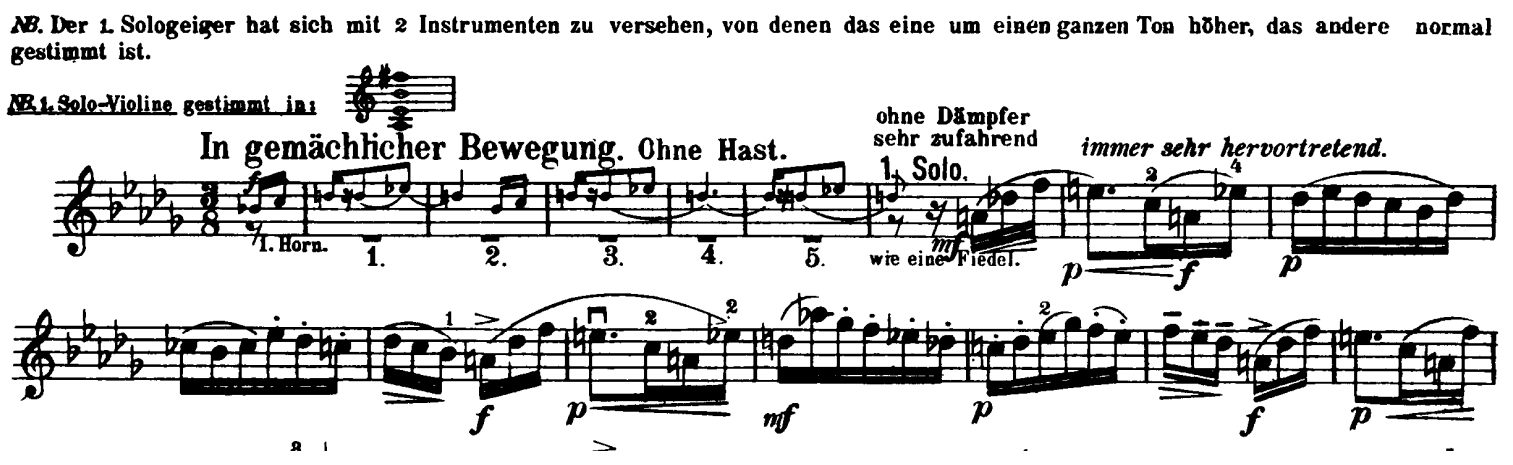


Em seu ballet O Pássaro de Fogo (1910), Igor Stravinsky em um momento pede para que os primeiros violinos abaixem a corda mi em um tom, para ré, para produzir uma série de arpejos em ré maior com harmônicos naturais.

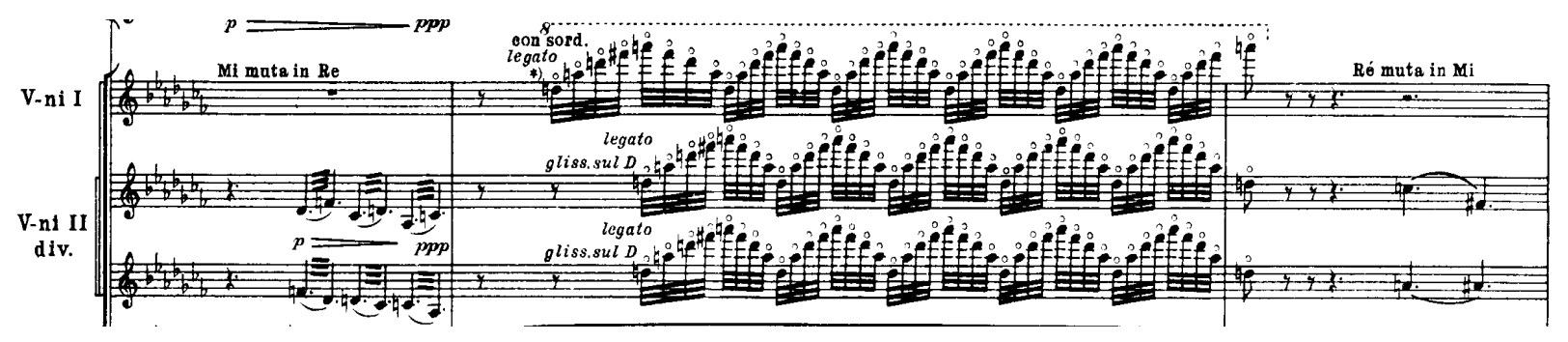

Em seu trio para piano, clarinete e violino denominado Contrastes, Bela Bartók pede que o violinista utilize dois instrumentos no início do terceiro movimento, um afinado normalmente e outro afinado em trítonos: sol sustenido-ré-lá-mi bemol.
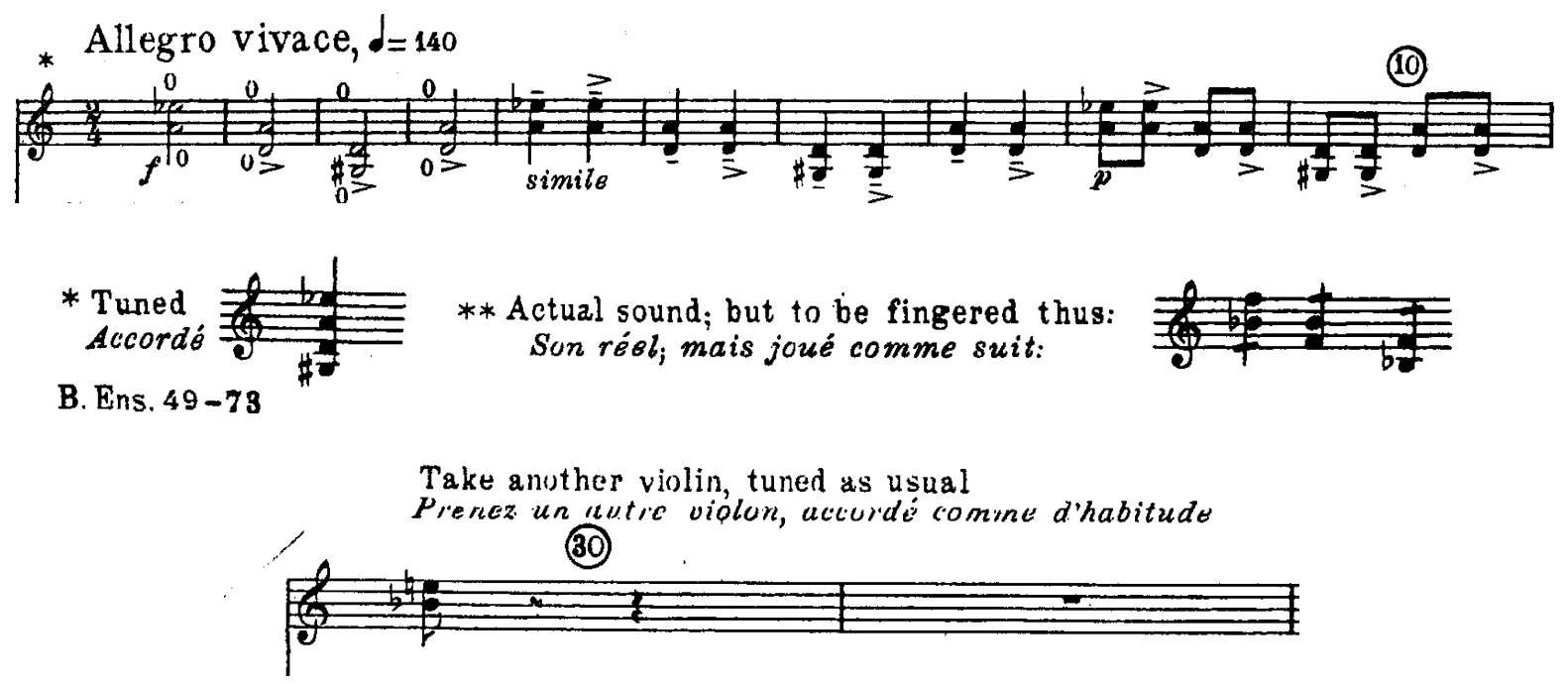

A scordatura na viola é dividida em duas categorias: "scordatura de transcrição" e "scordatura de não transcrição". Definido pelos historiadores David Boyden e Robin Stowell por seu mecanismo único, a "scordatura de transcrição" requer a afinação de todas as cordas meio tom ou um tom acima, com a finalidade de obtenção de uma ressonância mais expressiva, e a técnica surge em diversos concertos para viola no final do século dezoito e início do dezenove (BOYDEN, 2010).

A "scordatura de não transcrição" está presente em uma grande variedade de obras de câmara, solo e de orquestra. Entre as obras mais conhecidas estão a 
Suíte número 5 para violoncelo solo em dó menor de J.S.Bach, com transposição para viola, e o poema sinfônico Don Quixote, de Richard Strauss.

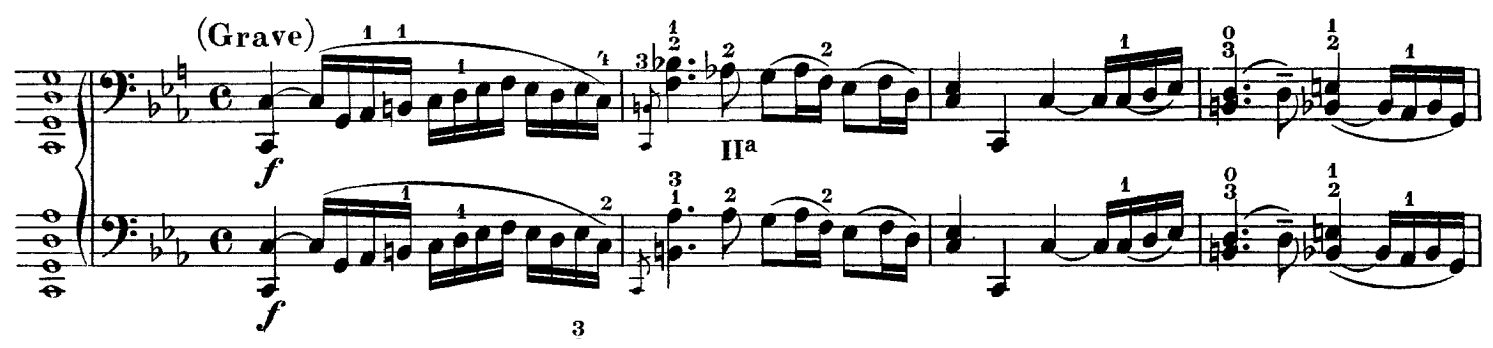

Pelo fato de a viola ser um instrumento raro na carreira solo, muitos violistas se preparam para tocar em orquestras, e, para isso, a scordatura encontrada em Dom Quixote é um desafio que não pode ser evitado. Com o subtítulo de Variações fantásticas sobre um tema de caráter cavalheiresco, a obra é solicitada na maioria dos testes para chefe de naipe de viola, para avaliar técnica, musicalidade e criatividade artística. O violista solo projeta o caráter de Sancho Pança, um cômico ajudante do perdido Dom Quixote, e que é evocado às vezes por instrumentos mais naturalmente engraçados, como o clarone e a tuba tenor.

No número 26 de ensaio ${ }^{85}$, é requisitado ao violista principal que altere a afinação de sua corda dó para si, e para que volte a afinação novamente para dó nos seis compassos de pausa no número de ensaio 28 .

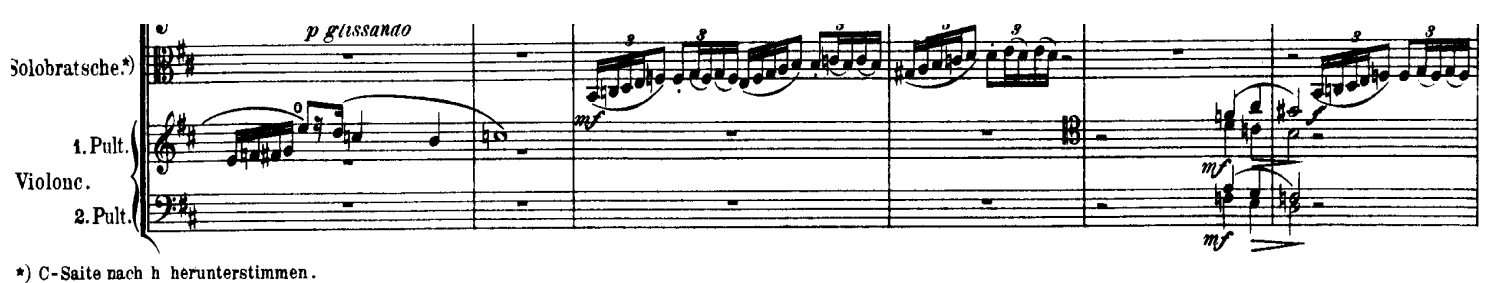

Em algumas apresentações, o violista principal simplesmente utiliza outra viola para as passagens em scordatura, e pega de volta a viola original com afinação padrão para tocar o restante da obra. Mas para aqueles que não podem ter uma viola reserva para tocar, existem outras alternativas.

O violista pode reafinar de acordo com a notação do compositor, durante as pausas, o que requer uma audição bastante treinada, pois é grande a dificuldade para afinar o instrumento durante a execução da orquestra. Para o violista mais

\footnotetext{
${ }^{85}$ Edição retirada de http://imslp.org/wiki/Don_Quixote,_Op.35_(Strauss,_Richard).
} 
cauteloso com relação à scordatura, existe um método muito prático que alivia as preocupações quanto a reafinação precisa e quanto à leitura potencialmente confusa da notação "com nota real", que é deixar a viola na afinação padrão, sem a scordatura, e tocar ré bemol ao invés do si.

Enquanto os violistas de orquestra podem escolher qual a melhor maneira de lidar com o desafio dessa passagem, não é impossível seguir o pedido original do autor e executar a scordatura nessa passagem. Se o instrumentista estiver disposto a praticar a afinação e reafinação corretamente e superar a dificuldade de leitura, será possível apreciar o novo timbre produzido pela corda afinada em si.

A Suíte n.5 de J. S. Bach BWV 1011 em dó menor para violoncelo solo, transcrita uma oitava acima para viola, é uma das obras mais requisitadas em concursos para orquestra e uma das obras solo mais executadas em salas de concerto. As instruções de Bach pedem que a corda lá seja afinada um tom abaixo, em sol, resultando dó-sol-ré-sol. Mas esse artifício é raramente utilizado, talvez pelo fato de que a versão com scordatura para viola é difícil de ser encontrada e normalmente nem é mencionada na maioria das edições. Mark Chambers (1996, p. 90), referindo-se mais à parte técnica do que à musical, diz que

A percepção moderna da utilização da scordatura por Bach tem sido rotulada como afinação 'facilitada' por instrumentistas talentosos e portanto conclui que o uso da scordatura é de alguma maneira uma abordagem menos desejável e deve ser evitada) ${ }^{86}$

Entretanto, Simon Rowland-Jones (1998, Preface 4), que arranjou e publicou esta suíte pela editora Peters, fez a seguinte observação:

Para a Suíte n.5 eu recomendo fortemente aos instrumentistas que utilizem a versão original com scordatura. Baixar a corda mais aguda para sol altera completamente a cor do instrumento, produzindo uma ressonância mais escura e mais profunda, muito apropriada para a tonalidade de dó menor. Além disso, a utilização hábil de Bach nessa afinação especial produz uma riqueza única nos acordes. ${ }^{87}$ (Preface)

\footnotetext{
86 “The modern perception of Bach's use of scordatura has even been labeled the 'easy' tuning by accomplished players and therefore implies that scordatura is somehow a less desirable approach and should be avoided"

87 "For Suite $n .5$ I strongly recommend players to use the original scordatura version. Lowering the top string to $G$ entirely alters the colour of the instrument, producing a darker, deeper resonance very appropriate to the key of C minor. Furthermore, Bach's skilful use of this special tuning produces a unique richness in chords"
} 
De fato, a utilização da scordatura realmente faz diferença na viola. Uma ressonância "escura, profunda" é possível somente através das quatro cordas soltas, afinadas em dó-sol-ré-sol, ou seja, com todas notas principais do acorde de dó menor e de sua dominante, criado assim uma maior sonoridade e projeção no instrumento.

De acordo com Chambers (1996, p. 83), esse efeito é mais bem observado no compasso de abertura do Prelúdio, onde os dois primeiros tempos incluem as duas cordas soltas mais graves (dó e sol), enquanto as duas outras (ré e sol) vibram e criam mais efeito sonoro.

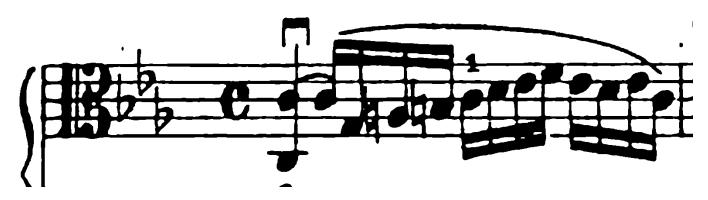

$\mathrm{Na}$ Allemande, Chambers encontra outra vantagem na utilização da scordatura. No primeiro tempo do compasso 30, não é possível deixar a corda solta ré vibrar durante um tempo inteiro na afinação padrão, sendo a vibração forçada a parar para a execução do lá bemol que vem a seguir. Com a utilização da scordatura, entretanto, é possível tocar seguindo a intenção original do compositor a corda solta ré e o lá bemol soando simultaneamente.

Rowland-Jones (apud BACH, 1998, introdução) defende o artifício da scordatura para a "riqueza singular nos acordes", e sem dúvida Bach tinha plena consciência dos efeitos sonoros da scordatura, já que escreveu inúmeros acordes nesta suíte, mais do que em qualquer outra das seis. Baseado na edição feita por Rowland-Jones, sete dos quinze acordes de quatro notas na quinta suíte podem ser produzidos por afinação padrão. Por exemplo, no prelúdio, o acorde de quatro notas no segundo compasso é impossível de ser tocado com a afinação padrão (BACH, 1998, introdução).

É importante observar que, ao alterar a afinação da corda, são necessários alguns cuidados. Pelo fato de a corda solta sol (lá alterada) ter menos tensão, é necessário utilizar menos pressão do arco ao tocar nessa corda. Muita pressão do arco pode resultar num indesejável som "arranhado". 
Outra obra de destaque no repertório dos violistas que originalmente foi escrita com a utilização da scordatura é a Sinfonia Concertante para violino e viola K.364 de W.A.Mozart.

É lógico concluirmos que Mozart, um habilidoso violista e violinista, compreendia os desafios acústicos que a viola enfrenta, especialmente quando comparados ao som mais brilhante e projetado do violino. A solução encontrada foi escrever a parte da viola em ré maior e fazer com que o violista afine seu instrumento meio tom acima, resultando numa scordatura de mi bemol.

O resultado é um instrumento com som mais brilhante e potente, devido à tensão das cordas ${ }^{88} \mathrm{~A}$ ressonância da viola também aumenta, já que três das cordas soltas correspondem à tônica (Mi bemol - corda ré aumentada), à subdominante (lá bemol - corda sol aumentada) e à dominante (si bemol - corda lá aumentada) da tonalidade de mi bemol. Desta maneira, a afinação também é facilitada, já que as cordas soltas são utilizadas com mais freqüência.

Compositores e instrumentistas frequentemente utilizam a scordatura pelos efeitos especiais que não podem ser realizados com a afinação original, como a ressonância, a facilidade em passagens difíceis e as sonoridades difíceis de ser produzidas.

Na metade do século XVII, o violino e a viola ainda estavam em período de desenvolvimento e, como tal, possuíam um braço grosso e pequeno, que ficava plano com o corpo. Durante o final do século XVIII, os luthiers começaram a alongar o braço e a colocá-lo num ângulo maior com o braço do instrumento, frequentemente cerca de quatro ou cinco graus (TARLING, 2001, p. 234-237). Um violino em seu período de transição, como no ano 1780, tinha um braço mais longo e mais curvado que um violino feito 100 anos antes.

Como já foi explanado, com o aumento de tamanho das salas de concerto e com aumento da demanda da música das cortes para a classe média crescente, o espelho maior e o aumento da tensão das cordas fez com que os instrumentistas produzissem um som mais penetrante e brilhante.

Os compositores do final do período clássico, entretanto, foram um passo adiante. Ao desenvolver a técnica da scordatura de transcrição, eles delinearam um

\footnotetext{
${ }^{88}$ A Scordatura auxilia também a diferenciar o som da viola solo do tutti.
} 
manual de procedimento para aumentar a tensão das cordas e produzir uma ressonância maior.

Diferentemente dos outros tipos de scordatura que resultam em diversos intervalos entre as cordas, a scordatura de transcrição exige a reafinação de todas as cordas em meio ou um tom acima e, com a notação transposta meio ou um tom abaixo, os instrumentistas são capazes de ler a parte "como dedilhada" ao invés de "como soa".

Embora no final do barroco e no início do classicismo os compositores não empregassem o procedimento na viola com tanta criatividade como no violino, a scordatura de transcrição na viola deu ao instrumento pela primeira vez uma personalidade solista.

A scordatura de transcrição na viola deu ao instrumento "maior brilho, ganhando potência e facilidade de execução" (BOYDEN, 1980, p. 892). Compositores do final do século XVIII que escreveram concertos para viola, como Johann Andreas Amon (1763-1825), Georg Druschetsky (1745-1819) e Johann Baptist Vanhal (1739-1813) frequentemente utilizavam a scordatura de transcrição para promover a viola e para auxiliar o violista em frente a uma orquestra (RILEY, 1991, p. 139-140).

Apesar das vantagens da scordatura de transcrição nesses concertos para viola do século XVIII, muitos instrumentistas permanecem contra a utilização do artifício. Alguns estudiosos da viola, como Riley (1991), acreditam que se se desejar realizar verdadeiramente a perspectiva histórica da época do compositor, a scordatura somente faz sentido se efetuada em instrumentos de época. Segundo Riley (1991, p. 143), "não é mais necessário afinar a viola meio tom ou um tom acima para que o instrumento seja ouvido em grandes salas de concerto".

Entre os concertos do final do século XVIII que utilizam a scordatura de transcrição, a Sinfonia Concertante, de Mozart, permanece a favorita, e, como a maioria de seus companheiros contemporâneos, o artifício da afinação designada é frequentemente negligenciado. Editores mais antigos a transpuseram de ré maior para mi bemol maior sem levar em conta o pedido de Mozart para a utilização da scordatura, excluindo, assim, a scordatura da parte da viola solo. Portanto, há violistas que desconhecem a história da scordatura na obra e não têm a opção de executá-la. 
Entretanto, Tertis publicou, em 1947, pela editora londrina Augener Limited, uma edição com a utilização da scordatura e, embora com alterações - substituiu a cadência de Mozart por uma própria - fez com que a utilização da scordatura nessa obra reemergisse. Edições mais atuais da obra apresentam as duas versões.

Para os violistas, uma vantagem de seguir as instruções de Mozart ao utilizar a scordatura é a leitura em ré maior, tonalidade que facilita a afinação, técnica e execução. Exemplos de facilitação em cordas duplas:

Ex.1

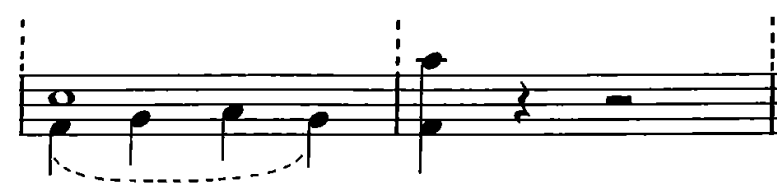

Figura 22 - 1ํmov. Cadência, comp 11-12 com scordatura

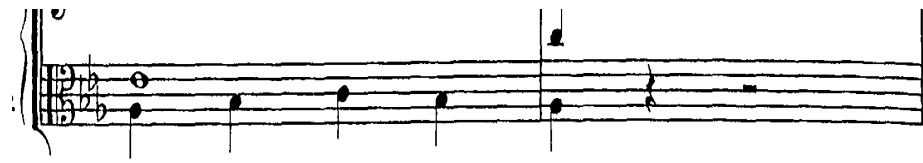

Figura 23- $1^{\circ}$ mov. Cadência, comp. 11-12 sem scordatura

Ex.2:

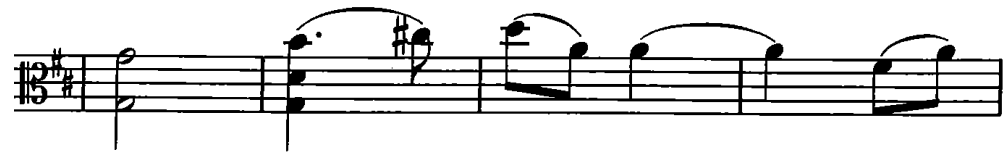

Figura 24 - 3ํㅡㅇ. Cadência, comp. 279-282 com scordatura

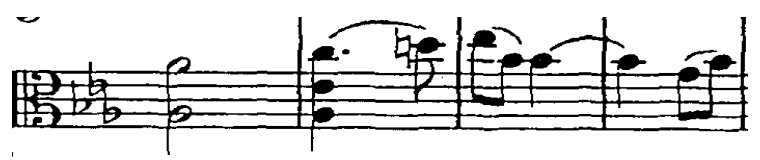

Figura 25 - 3ำ mov. Cadência, comp. 279-282 sem scordatura 
Exemplos de facilitação em dedilhados:

Ex.1:

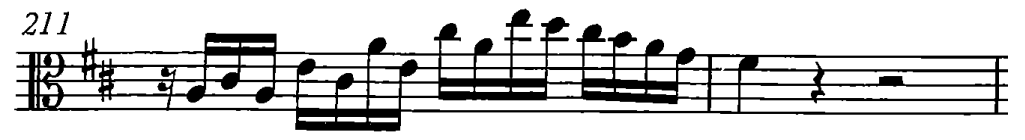

Figura $26-1^{\circ}$ mov. Compassos 211-212 com scordatura

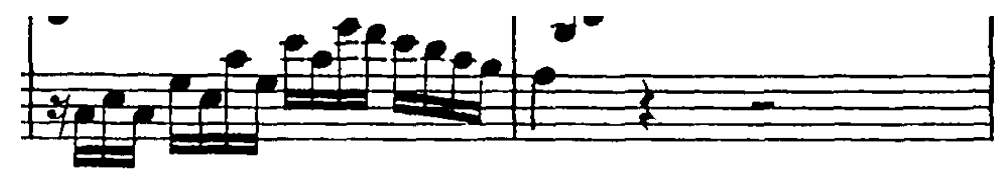

Figura 27 - 1ํmov. Compassos 211-212 sem scordatura

Ex.2

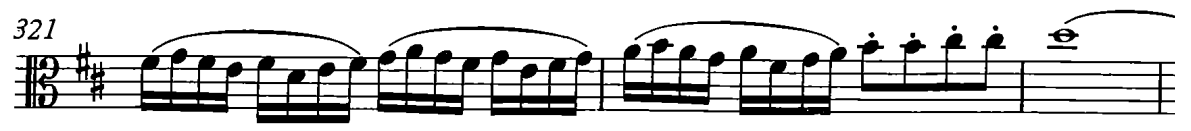

Figura 28 - 1ำ mov. Compassos 321-323 com scordatura

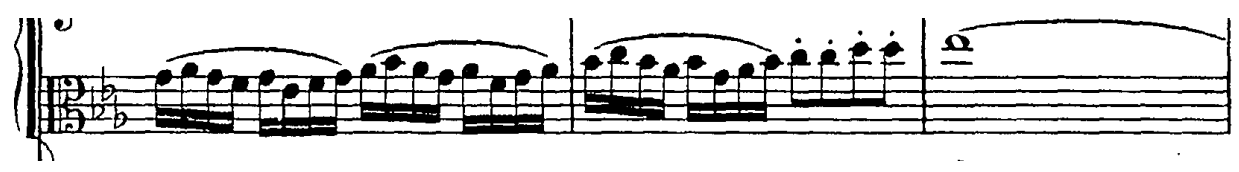

Figura 29 - 1ํㅡov. Compassos 321-323 sem scordatura

Exemplos de facilitação em mudanças de corda:

Ex. 1

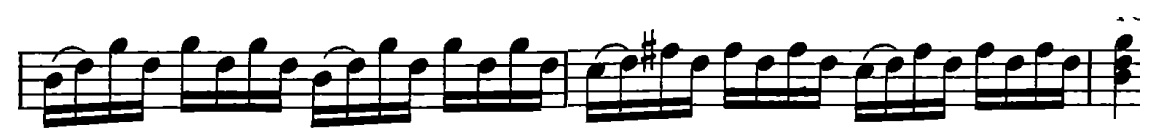

Figura 30 - $1^{\circ}$ mov. Compassos $156-158$ com scordatura

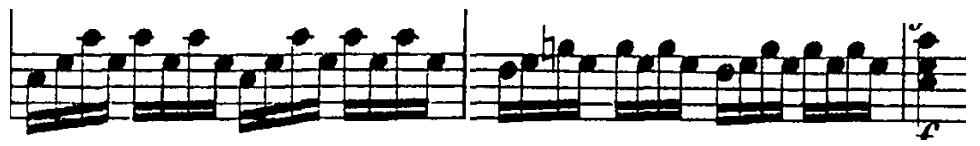

Figura $31-1^{\circ}$ mov. Compassos 156-158 sem scordatura 
Ex.2:

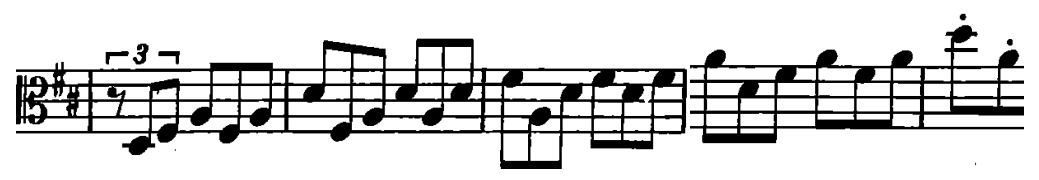

Figura 32 - 3ํㅡㅇㅢ. Compassos 435-439 com scordatura

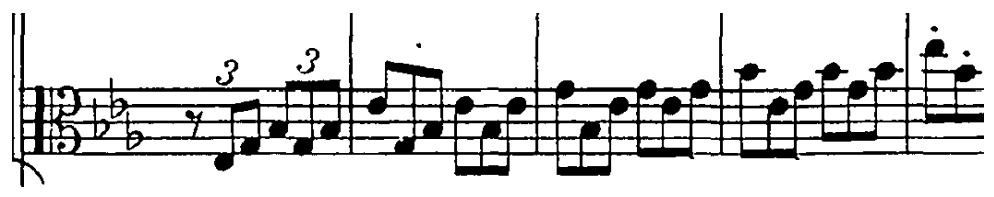

Figura 33 - 3o mov. Compassos 435-439 sem scordatura

Uma vez aprendida, a scordatura auxilia o instrumentista na execução de passagens técnicas difíceis, a resolver problemas de afinação e a tocar com mais brilho. Um estudo mais aprofundado da técnica mostra mais sobre o instrumento e suas possibilidades do que qualquer livro metodológico. Um estudo cuidadoso das vantagens e desvantagens sobre a utilização da scordatura na Sinfonia Concertante, de Mozart, é válido ao violista que encontra instruções similares de outros compositores, como Bach e Strauss.

A scordatura foi e continua sento utilizada tanto no violino quanto na viola com a finalidade de aumentar a tessitura do instrumento ou de possibilitar acordes que seriam impossíveis de serem executados sem esse artifício, além de facilitar a execução de passagens musicais difíceis e modificar o timbre do instrumento. 


\section{PARTE III}

\section{Didática}

Nos instrumentos de cordas, técnica é definida como a "habilidade de controlar mentalmente e executar fisicamente todos os movimentos necessários de mão direita e esquerda, braços e dedos." (GALAMIAN, 1962, p. 5) ${ }^{89}$. Esta habilidade para controlar e executar nos permite tocar os instrumentos musicais e é fundamental para o progresso. A noção de que todos os aspectos da música podem ser ensinados, incluindo movimentos físicos e percepção aural, surgiu recentemente, se comparada à longa história da pedagogia dos instrumentos de cordas. Carl Flesch (1930, v.1 p.5) dizia que "cor e volume de som, técnica de mão esquerda e de arco, ouvido para a afinação apropriada - tudo pode ser adquirido e aperfeiçoado, pois as funções dos órgãos que participam delas são suscetíveis a verificação e acessíveis a influências externas". 90

Enquanto nos últimos anos houve avanços significativos na área de pedagogia de instrumentos de cordas, o conjunto de obras pedagógicas se estende por séculos, englobando diversos tipos de peças, incluindo exercícios, estudos e caprichos. Desde o início, a transferência de conhecimento do professor para o aluno é muito importante, e os professores têm vencido desafios para realizar isto.

Estudos e exercícios são ferramentas pedagógicas para o crescimento técnico-musical que abordam esse desenvolvimento de diferentes maneiras. Enquanto exercícios são pequenos e frequentemente enfatizam aspectos somente técnicos, os estudos incorporam esses aspectos técnicos juntamente com os musicais.

Já que a literatura musical é composta por uma combinação desses elementos, os estudos oferecem um treinamento precioso para estudantes e profissionais. Os estudos geralmente isolam um aspecto da técnica e o exploram dentro de um contexto musical. A musicalidade nos estudos é importante e ajuda a evitar o toque mecânico, armadilha típica dos exercícios.

\footnotetext{
89 "The ability to direct mentally and to execute physically all the necessary playing movements of left and right hands, arms and fingers"

90 "Colour and volume of tone, bowing and finger technique, ear for proper intonation-all these may be acquired and improved, because the functions of the organs which participate in them are susceptible to verification, and are accessible to external influences"
} 
Existem quase tantas definições para a palavra "estudo" quanto livros que as contêm. Além disso, essas definições variam em extensão e detalhes. Uma seleção delas pode esclarecer o que são os estudos e revelar seu propósito na pedagogia dos instrumentos de cordas. É um termo generalizado para definir um grande conjunto de material pedagógico. "No emprego atual, o estudo se encontra entre o exercício, uma fórmula pequena não trabalhada com uma composição formal, e o estudo de concerto, que pode ser colocado como uma peça de música autosuficiente". ${ }^{91}$ (NEW HARVARD, 2010).

O The Harvard Dictionary of Music define os estudos como obras "designadas para auxiliar o estudante de um instrumento a desenvolver sua habilidade mecânica [...] normalmente voltados completamente para um dos problemas especiais da técnica do instrumento, como escalas, arpejos, oitavas, cordas duplas, trinados, etc." "92 (NEW HARVARD, "etude").

O The New Grove a define de maneira similar, descrevendo que os estudos são "claramente pequenas peças cujo objetivo principal é a exploração de um aspecto particular da técnica de performance." 93 (THE NEW GROVE DICTIONARY, "etude").

A maioria concorda que há algum elemento musical presente juntamente com os elementos técnicos nos estudos. O grau de musicalidade encontrado em um conjunto de estudos é um fator que separa um conjunto de estudos de outro e algumas vezes faz com que um seja mais preferível que o outro.

Os estudos frequentemente não contêm "alto valor artístico", mas existem também em diversas outras formas diferentes: caprichos, variações, sonatas, prelúdios, fugas, invenções (STOLBA, 1968, p.256). Em 1836, Robert Schumann disse que todas as obras musicais são essencialmente um estudo, mas um estudo típico foca sua atenção em uma área específica de dificuldade - técnica, musical, rítmica, expressiva, interpretativa - e as obras que exploram mais que um desses elementos deve ser denominada "capricho" (STOLBA, 1968, p.27). Carl Flesch, (1930,v.1 p.91) por outro lado, diz que aos estudos "normalmente faltam a qualidade

\footnotetext{
91 "In a present-day usage, the etude falls between the exercise, a short formula not worked out as a formal composition, and the concert etude, which can stand as a self-sufficient piece of music."

92 "designed to aid the student of an instrument in developing his mechanical ability... usually devoted entirely to one of the special problems of instrumental technique, such as scales, arpeggios, octaves, double stops, trills, etc."

${ }_{93}$ "fairly short pieces whose principal aim is the development or exploitation of a particular aspect of performing technique".
} 
inerente em uma composição nascida de um impulso puramente musical" e afirma que "não são adaptados para a performance pública e, na maioria dos casos, seu objetivo principal é aumentar o preparo técnico do instrumentista". ${ }^{94}$

Para o propósito desta dissertação, a palavra estudo denota "uma composição completa com intenção e conteúdo pedagógico que retrata pelo menos um problema consistentemente recorrente de dificuldade psicológica, técnica ou musical, que exige do instrumentista não somente aplicação mecânica, mas também estudo apropriado e correta interpretação." "95 (GANZ, 1960, p.12)

A definição de "exercício" parece similar, porém as diferenças principais estão na duração e no foco. Enquanto os estudos de Kreutzer possuem em média duas páginas, muitos exercícios de Ševčík possuem um ou dois compassos. Os exercícios focam um aspecto específico da técnica, como por exemplo a independência dos dedos, e excluem praticamente todos os outros aspectos da música, enquanto os estudos combinam elementos técnicos e musicais. Não se procura tocar os exercícios musicalmente, já que sua função primária é técnica, não musical, embora as considerações musicais possam ser feitas, mas não são inerentes ao exercício. Outra diferença fundamental entre exercícios e estudos está em sua publicação. Livros de exercícios normalmente focam um tópico, enquanto os de estudos são publicados tipicamente em conjuntos arranjados, com volumes separados por assuntos técnicos.

Pelo fato de os estudos serem composições completas, estes incorporam diversos fatores musicais. Segundo K. Marie Stolba, um virtuoso não deve ser uma máquina, mas um artista, e artistas são formados pelos estudos, não pelos exercícios. (STOLBA, 1968, p.7) Ela também diz que a musicalidade dos estudos de Rode faz com que eles soem mais como caprichos do que como estudos (STOLBA, 1968, p.245). Carl Flesch referiu-se aos estudos de Kreutzer, Rode e Dont como "composições musicais" (FLESCH, 1939, v.1, p.115) e Primrose acrescentou que "se os trabalhos técnicos continuarem a ser tocados com uma mão morta e sem

\footnotetext{
94 "They usually lack the musical value of compositions which owe their creation to musical inspiration alone." "They do notlend themselves to public performance, and their purpose is maily to enlarge the technical abilities of the player".

95 "denotes a complete composition with pedagogic intent and content that features at least one consistently recurring problem of phsysiological, technical or musical difficulty which requires of the player not only machanical application, but proper study and cprrect interpretation as well".
} 
movimentos muito além dos estágios iniciais do desenvolvimento do aluno, pode ser prejudicial." ${ }^{\text {"D }}$ (DALTON, 2003, p.157)

Primrose resumiu isso adequadamente quando perguntou "Por que praticar de uma maneira e tocar de outra?"97 (DALTON, 2003, p.107)

Flesch creditou a evolução da técnica do violino a Otakar Ševčík (18521934), cujos exercícios mudaram a maneira de tocar violino e permitiu aos violinistas resolverem as dificuldades técnicas que anteriormente seriam complicadas de superar. Suas contribuições ao material didático são significantes com a publicação de seu School of Violin Technique e School of Bowing Technique e sua influência nas obras de Schradieck (1846-1918), Sauret (1852-1920), Hubay (1858-1937), Sitt (1850-1922), Spiering (1871-1925) e Auer (FLESCH, 1939, v.1 p.114). A linha entre exercícios e estudos é claramente traçada pela declaração de Flesch (1930, v.1 p.115)

Os estudos de Kreutzer, Rode ou Dont são, apesar de tudo, composições musicais, ao passo que Ševčík não somente nem ao menos faz uma tentativa de dizer-nos algo de natureza musical, mas procura desenvolver os problemas técnicos com absoluta desconsideração da forma e do conteúdo musical ${ }^{98}$

Carl Flesch (1939, v.1 p.116) declara ainda que os exercícios de Ševčík são "os mais importantes meios de economizar tempo para obter a moderna técnica do violino"99, enfatizando que é necessário que sejam executados de maneira adequada. Ele afirma que os exercícios de Ševčík devem ser executados com moderação para evitar fadiga mental e obter bons resultados e dá a seus alunos instruções cuidadosas para o estudo de Ševčík - com quais exercícios começar, quanto tempo praticá-lo, concentração na afinação e pureza de som, etc (FLESCH, 1939, v.1 p.115).

O Ševčík Opus 1 parte 1 foca a independência e velocidade dos dedos da mão esquerda, todos na primeira posição - tratando de arco somente no final do livro - enquanto o Opus 8 foca somente as mudanças de posição. Esses dois volumes são compostos por pequenos padrões que geralmente tratam de um

\footnotetext{
96 "If technical works continue to be played with a dead and motionless hand far beyond the beginning stages of a student's development, this can be deleterious". Dalton, 157

97 "why practice one way and perform another?"

98 "The etudes of Kreutzer, Rode and Dont are after all musical compsitions, while Sevcik does nota t all try to say anything musical. He only intents to deal with technical problems, totally ignoring form or musical content". 99 "Sevcik's study works to be the most important and time-saving contributions along the Road to achieving a modern violin technique"
} 
problema técnico de cada vez. Estes são apenas dois dentre diversos volumes publicados deste autor, cada um focando uma parte específica do estudo da técnica.

O The School of Violin Technics de Henry Schradieck (1951) e o Modern Viola Technique de Robert Dolejsí (1939) também focam a destreza e independência dos dedos da mão esquerda. Ambos incluem trabalho significante na variedade de posições, e, enquanto o livro de Dolejsí é baseado nas escalas, o de Schradieck tem seus exercícios baseados em escalas e arpejos, utilizando frequentemente escalas como base, alguns cromatismos e cordas duplas. Schradieck explora mais variações de tonalidades que Dolejsí - este utiliza quase que exclusivamente o dó maior. Os exercícios de ambos os livros são bem sucintos. A premissa básica de Dolejsí é que "é natural acreditar que se essas combinações de dedos são desenvolvidas ao mais alto grau de perfeição em todas as posições normalmente utilizadas na viola, uma técnica impecável é alcançada". ${ }^{100}$ (DOLEJSí,1939, p.2)

O método de Dolejsí foca duas áreas - a simplificação dos problemas técnicos para que possam ser resolvidos rapidamente e o desenvolvimento da concentração (DOLEJSí, 1939, p.2). Segundo Dolejsí (1939, p.3), o princípio primordial no estudo do instrumento de cordas é a prática lenta, facilitando a percepção de erros que não deveriam permanecer sem correção. Por essa razão, ele pretendia que seus exercícios fossem tocados de cor, pois desta maneira a atenção na técnica ao praticar lentamente os exercícios e na audição não é desviada pela leitura. Seu livro trabalha todas as posições, incluindo as poucas variações básicas de arco e de ritmo, e algumas cordas duplas, e utiliza todas as tonalidades. Seu método é ordenado e extremamente repetitivo.

Em seu livro Urstidien (1990), Carl Flesch foca sua atenção na independência e coordenação dos dedos, como Dolejsí e Schradieck e, utilizando exercícios para o arco além daqueles para a mão esquerda. Algumas vezes os golpes de arco são longos e sustentados em uma corda, mas tanto Schradieck quanto Flesch incorporam as mudanças de corda com os problemas de mão esquerda, fornecendo um estudo eficiente (FLESCH, 1939, v.1 p.113). O livro de Flesch tem mais escalas como base e apresenta uma forma mais resumida em extensão que o Schradieck e o Dolejsí.

\footnotetext{
100 " it is but natural to believe that, if these finger combinations are developed to the highest degree of perfection in all the positions normally used on the viola, an impeccable technique is attained".
} 
Dois volumes de William Primrose e um de Melvin Berger também tratam a técnica por meio das escalas. No The Art and Practice of Scale Playing on the Viola, Primrose utiliza as escalas como base para exercícios modais. Ele mantém sua abordagem modal em Technique is Memory, que inclui também padrões de dedilhado para aperfeiçoar a coordenação, velocidade e força. O Basic Viola Technique de Berger compreende um livro de escalas, tratando do mesmo material básico que Flesch direcionou para os alunos menos avançados, e também estende o alcance do material incorporando exercícios no final. Seus exercícios tratam de um número restrito de tópicos, que são tratados brevemente. Berger inclui variações de arco similares às utilizadas no $\operatorname{Kreutzer}^{101}$ n.2: pizzicato de mão esquerda, mudanças de cordas, pizzicatos, cordas duplas e acordes. O tratamento que ele dá a cada tópico é mínimo, no entanto, o aspecto interessante desse livro é a inclusão de excertos de outros estudos ou obras utilizando essas habilidades. Os exemplos da literatura são importantes, pois aplicam imediatamente os conceitos ensinados, realizando uma conexão muitas vezes pouco abordada (BARRETT,1978, p.102)

Enquanto os exercícios contidos no The Artist's Technique of Violin Playing de Dounis (1921) são mais longos que os contidos no Ševčík e no Schradieck, são baseados em um padrão e muito repetitivos. A primeira parte é concentrada na independência dos dedos e a segunda é composta por exercícios de mudança de posição, tanto em notas simples como em cordas duplas. A terceira seção é breve e contém variações de arcadas utilizando mudanças de cordas e staccato volante. Seu Specific Technical Exercises (1943) é uma versão concentrada do primeiro livro, contendo material similar de forma abreviada.

Enquanto os aspectos técnicos dos estudos são frequentemente discutidos, os elementos musicais são também importantes, já que a técnica é inseparável do propósito expressivo da música, e isso é o meio para o fim - "uma ferramenta a ser utilizada a serviço da interpretação artística." ${ }^{102}$ (GALAMIAN, 1962, p. 6). Se a técnica é essencial e a música é ineficaz sem algum nível de facilidade técnica, a arte da música não é puramente técnica. Essa combinação de esforços artístico e técnico é bem expressada pela afirmação de Carl Flesch (1930 v.2 p.129) "nossa

\footnotetext{
${ }^{101}$ Kreutzer, Rudolph. 42 Studies or Caprices: Violin Method. New York: Schirmer. 1987

102 "The tool to be used in the service of artistic interpretation".
} 
arte não é um problema de truques individuais, mas existe pela razão da combinação da habilidade de um artesão e pelo desejo artístico de fazer". ${ }^{103}$

A função principal dos estudos é, portanto, "construir técnica que funcione musicalmente, que surja do domínio dos aspectos técnicos e musicais dos estudos". ${ }^{104}$ (GALAMIAN, 1962, p.107). Primrose encoraja os alunos a tocar os estudos com vibrato e boa sonoridade (DALTON, 2003, p.157). Galamian diz que "a passagem tem que ser dominada de um ponto de vista puramente técnico, deve ser estudada como uma obra musical, no contexto de um de uma seção maior e com a expressão adequada." ${ }^{105}$ (GALAMIAN, 1962, p.101)

Os estudos e as escalas não são escritos para ser tocados em público, mas para auxiliar na preparação para a performance. Primrose satirizava dizendo que se um aluno é capaz de começar a estudar o Concerto de Bartók logo pela manhã, proporciona então mais força a ele, sabendo que esse aluno representaria a exceção ao invés da regra. (DALTON, 2003, p.43)

O objetivo de qualquer trabalho técnico é prover os alunos "com todas as ferramentas técnicas para que suas idéias musicais possam ser completamente realizadas”. ${ }^{106}$ (GALAMIAN, 1962, p.5). Segundo Louis Kievmann (1910-1990), a proposta por trás dos estudos é desenvolver uma figura mental dos movimentos antes de tocar (KIEVMANN, 1969, introdução). Os alunos podem também aprimorar o conhecimento da teoria, já que "através dos estudos de leitura, os alunos podem aprender a reconhecer as progressões harmônicas, escalas, arpejos e dificuldades técnicas no ato."107 (KIEVMAN, 1969, introdução). Isso dará claramente instruções aos professores para o início. Mais tarde, quando os alunos adquirem mais independência e conhecimento, pode-se pedir a eles que analisem os estudos. Kievman (1969, introdução) diz que "compreensão mental leva a um controle maior do que quando se utiliza somente a força física"108.

\footnotetext{
103 "Our art is not a matter of individual tricks, but exists by reason of the combination of craftsman-like ability and by the artistic will to do".

104 "buld technique that functions in a musical setting, nd many of the standard etude works may be used to advantage."

105 "the passage has been mastered from a purely technical point of view, it must be practiced agaín as a piece of music, in the contexto f a larger section and with the expression that is its due".

106 "with all the technical tools so this musical ideas may be fully realized."

107 Trough reading etudes, students can learn to recognize harmonic progressions, sacales, arpeggios, and technical difficulties at sight."

108 "mental understanding leads to more control than does physical strenght alone".
} 
A prática de técnicas para os estudos são similares àquelas para outros tipos de literatura. Segundo Primrose,

não devemos simplesmente tocar os estudos cegamente. Sempre deve haver um motivo. E nós tocamos os estudos também porque é mais divertido que tocar um estudo insípido... Penso que isso pode prender a atenção do aluno tanto quanto qualquer outra coisa. Ele sabe que está cumprindo seu dever e se divertindo ao mesmo tempo. ${ }^{109}$ (DALTON, 2003, p.38)

Primrose recomenda a utilização de escalas e estudos para a preparação de performances somente se foram prazerosas, mas não se foram tratados somente como obrigação (DALTON, 2003, p.34).

As transcrições fornecem aos violistas muitos livros importantes além dos escritos especificamente para viola. São uma fonte viável, considerando que a prática da teanscrição era muito comum entre compositores. Enquanto os violistas esforçam-se para tocar obras originais para viola, as transcrições também são materiais encontrados de estudo e performance.

Muitos dos livros de estudos mais comuns de violino foram transcritos para viola (Kreutzer e Rode, por exemplo) e são frequentemente utilizados pelos violistas. Até o início do século $X X$, quando não era esperado que os violistas tocassem no mesmo nível que os violinistas, isso não teria sido razoável.

Entretanto, nos anos mais recentes, com o aumento da popularidade da viola e com as obras com mais dificuldades técnicas escritas para este instrumento, é exigido um maior nível técnico, similar ao do violino. Por esta razão, os estudos de violino são comum e efetivamente utilizados para o desenvolvimento da técnica de viola.

Os elementos envolvidos na execução da viola e do violino são essencialmente idênticos. De acordo com Carl Flesch (1930, v.2 p.128): "a parte técnica de tocar violino se reduz a três exigências: clareza de afinação, pureza do som e tempos corretos. Todos os erros puramente violinísticos atendem a pelo menos um destes requisitos". ${ }^{110}$.

\footnotetext{
109 "We simply mustn't play études blindly. There must be a reason. And we also play études because it is more fun than playing a dry study... I think that this can engage a student's attention as much as anything else”.

110 "The technical part of violin playing reduces itself to three demands: purity of intonation, purity of tone and correct tempos. Every purely violinistic error offends against one, at least, of these requirements"
} 
Ivan Galamian (1966, p.3) lista três diferentes fatores ao tocar: "físico (estrutura anatômica, flexibilidade), mental (como a mente prepara e então direciona a atividade muscular) e a estética/emocional (entender o significado da música e a habilidade de expressá-la)" ${ }^{111}$.

Existem diferenças sutis entre a técnica do violino e a da viola, mas os conceitos podem ser transferidos, fazendo com que os estudos para violino se tornem apropriados e úteis para os violistas.

Mesmo que a palavra "estudo" não tenha sido comumente utilizada antes do século XIX, muitos compositores escreveram obras didáticas ${ }^{112}$. Segundo David Boyden (1980, p. 246):

A educação dos violinistas provavelmente se iniciou com a execução de danças e melodias simples, que podiam ser elaboradas com variações, então progredindo com ornamentos, figurações violinísticas de várias espécies e o trabalho da técnica de posições e cordas duplas. ${ }^{113}$

Algumas das obras mais antigas para instrumentos de cordas, que podem também ser utilizadas como obras didáticas, como o Capriccio Stravagante de Carlo Farina (1600-1644) e as sonatas e a Passacaglia para violino solo de Heinrich Biber (1644-1704), que prepararam o caminho para as sonatas de J. S. Bach (1685-1750) (STOLBA, 1968, p. 32). Embora atualmente não se acredite mais que tenha sido o primeiro método de violino, The Art of Playing on the Violin, de Geminiani (16871762), publicado em 1751, é ainda considerado um dos primeiros tratados importantes (RODRIGUES, 2009, p.33).

Geminiani apud Rodrigues (2009, p. 23-24) escreveu este volume em meio a uma tendência de estudo por conta própria na Inglaterra devido à escassez de professores, que na época concentravam-se na Itália, onde a tradição de ensino era oral. "Ele não escreveu para o músico amador, nem estava preocupado com o desenvolvimento do virtuoso; seu objetivo era especialmente a perfeição do violinista como um artista." ${ }^{114}$ (STOLBA, 1968, p. 58).

\footnotetext{
111 "Physical (anatomical srtucture, flexibility), mental (how the mind prepares and then directs muscle activity), and the aesthetic/emotional (understending the meaning of music and the ability to express it)"

${ }^{112}$ The New Harvard Dictionary of Music, s.v. "Etude".

113 "The education of violinists probably began with playing simple dances and tunes, which might be elaborated by variations, then proceeding onward to ornaments, violin figurations of various sorts, and work in the positions and Double-stop technique”

114 "He did not write for the music amateur, nor was He concerned with the development of the virtuoso; rather, his aim was the perfection of the violinist as an artist".
} 
Outra antiga obra pedagógica, L’arte del violino, escrita em 1733 por Pietro Locatelli (1695-1764), consiste em doze concertos com cadência para violino e vinte e quatro caprichos para violino solo (KOOLE; TALBOT, s/d). Alguns professores defendiam sua arte e procuravam passar seus métodos exclusivamente para seus alunos, o que explica os atrasos nas publicações, como os estudos de Gaviniés, por exemplo, ou publicações póstumas (STOLBA, 1968, p. 40). Outros, como Spohr, escreveram estudos para o desenvolvimento de técnicas especiais exigidas em suas composições (FLESCH, 1930, v.1 p.114).

No final do século XVIII e início do séc. XIX, diversos métodos entitulados Méthode d'alto foram publicados, incluindo os de Michel Corette em 1782, Jean B. Cupis em cerca de 1788, Michel Woldemar em cerca de 1795, Bartolomeo Bruni em 1805, J.J. Gebauer em 1816 e Jacob Martinn em cerca de 1815 (RILEY, 1980, p. 167-168). Estudos compostos especificamente para violistas incluem os 12 ViolaEtuden de Franz Anton Hoffmeister, escritos em cerca de 1800, e coleções de Alessandro Rolla (ca.1820), Alexis de Garaudé (1823), Casimir-Ney (ca. 1850), León Firket (1873) e Hilaire Lütgen (1874) (RILEY, 1980, p. 167-168).

A "atenção sistemática na técnica de dedilhado assegura sua importância na fundação dos métodos modernos de ensino de violino"115. Schradieck (1846-1918) publicou diversos estudos importantes de técnica para violino, incluindo os 25 Grosse Studien für Geige allein, Scale Studies, Guide to the Study of Chords, Finger Exercises e o Schule der Violintechnik em três volumes, que foram adaptados para violistas. $^{116}$

Obras didáticas refletem os estilos musicais contemporâneos e a evolução na construção dos instrumentos, como é perceptível nos métodos compostos nos anos 1700, que frequentemente incluem peças de dança em forma binária e raramente vão acima da terceira posição (STOLBA, 1968, p. 250). Segundo Stolba (1968), a utilização de formas binárias e a utilização do termo e gênero "capricho" são dois fatores constantes no desenvolvimento do estudo.

A idéia dos estudos pode ter se originado devido à abundância de músicos de classe média no final do século dezoito e início do século dezenove e da

\footnotetext{
${ }^{115}$ New Grove Dictionary of Music and Musicians, s.v. "Schradieck, (Carl Franz) Henry," por Cobbett W.W. \& Charlton David.

${ }^{116}$ Ibid.; Baker, s.v. "Schradieck, Henry".
} 
emergência de concertos públicos e da música impressa, como conseqüência da Revolução Francesa (STOLBA, 1968, p. 12).

Como a popularidade do violino aumentou, um público interessado buscou instrução e consequentemente mais métodos foram publicados e gradualmente se tornaram mais abrangentes (STOLBA, 1968, p. 250). A tradição anterior de ensino que se baseava na transmissão oral de conhecimento e porções de ensino avançado eram vistas como "segredos impagáveis da arte" (BOYDEN, 1980, p. 244).

Os primeiros livros de técnica de violino eram destinados aos amadores e o nível técnico era significantemente abaixo dos virtuoses contemporâneos, já que estes eram muito ocupados com as performances ou não tinham as qualidades literárias necessárias para escrever (BOYDEN, 1980). Os primeiros tratados de técnica de violino da Inglaterra e da Alemanha, onde havia muitos violinistas amadores, demonstram o crescimento da técnica de violino e o declínio geral das viols (STOLBA, 1968, p. 245). Leopold Mozart viu seu Violinschule, publicado em 1756, como o "primeiro livro verdadeiro de ensino do violino", mas é possível que ele simplesmente não tivesse conhecimento de tratados mais antigos (STOLBA, 1968, p. 246).

A música para violino derivou-se primeiramente de modelos vocais, mas assim que tornou-se mais independente e elaborada tecnicamente, o interesse em explorar completamente o instrumento cresceu, o que exigiu mais material instrutivo do que havia disponível anteriormente (STOLBA, 1968, p. 45).

Os primeiros escritos sobre o violino eram descritivos, contendo listas de fundamentos. Mais tarde foram escritos métodos com exercícios práticos e, finalmente, livros completos que continham estudos foram compilados (STOLBA, 1968, p. 13 e 250). Até meados do século XVIII, livros de métodos continham estudos que tinham geralmente o tamanho de uma página e, até 1787, foram publicados livros completos de estudos, infelizmente sem datação, ficando, assim, difícil estabelecer uma ordem exata de publicação (STOLBA, 1968, p. 250-252).

No início da escola francesa de violino, havia um grande interesse na música descritiva e nas danças. "De fato, o progresso técnico da escola francesa de violino durante todo o século dezessete foi impedido pelas limitações naturais da música de dança e pela noção de que a música só era boa à medida que retratasse algo" (BOYDEN, 1952, p. 21). 
No final do século XVIII e início do XIX foram particularmente produtivos com relação à pedagogia dos instrumentos de cordas. Durante esse período, Pierre Gaviniès (1728-1800), Pierre Rode (1774-1830), Rudolph Kreutzer (1766-1831), Federigo Fiorillo (1755-1823) e Pietro Rovelli (1793-1838) escreveram estudos. Carl Flesch separou Kreutzer e Rode dos outros deste grupo, justificando que são os de mais valor e "irão provavelmente satisfazer por todo o tempo a base mais sólida da habilidade violinística" (FLESCH, 1930, v.1 p.114).

No século XIX, foram publicadas diversas coleções importantes de estudos de violino, assim como de outros instrumentos. Nessa época, foram compostos muitos estudos para piano, por compositores como Carl Czerny (1791-1857), J. B. Cramer (1771-1858) e Muzio Clementi (1752-1832), que foi nomeado o fundador do estudo moderno, embora o termo "estudo" tenha sido utilizado na literatura do violino mais de dez anos antes de sua utilização na literatura do piano (STOLBA, 1968, p.257).

No ano 1800, o Conservatório de Paris teve um papel crucial no desenvolvimento do estudo, pois era onde os maiores professores da época se encontravam, e sua demanda por material didático facilitou o crescimento do estudo como forma. Gaviniès, Kreutzer, Rode e Baillot eram professores do Conservatório de Paris, e Gaviniès, Rode e Kreutzer escreveram estudos utilizados pelos violistas (STOLBA, 1968, p. 42).

Os membros do corpo docente eram encarregados de criar obras didáticas, que resultaram nos Méthodes Du Conservatoire. Baillot editou os métodos para violino e violoncelo, formulando o Méthode du Violon em conjunto com Rode e Kreutzer, além do Art du Violon (STOLBA, 1968, p.42).

Os compositores do século XIX reconheceram o potencial musical dos estudos, que levaram aos estudos de concerto de Chopin, Liszt e Scriabin, entre outros, para piano e de Paganini para violino. ${ }^{117}$ Em contraste aos estudos cujo objetivo era a prática, mas não a performance pública, os estudos de concerto tornaram-se tanto os fins quanto os meios para chegar aos fins. ${ }^{118}$

Os estudos naquela época eram editados em grande quantidade, mas sua circulação era limitada (RILEY, 1980, p. 183). Os professores de violino preferiam utilizar os métodos com os quais eram familiarizados, e os professores de viola

\footnotetext{
${ }^{117}$ New Harvard. "Etude".

${ }^{118}$ Ibidem.
} 
tipicamente utilizavam versões transpostas do Kreutzer, Mazas, Kayser ou Fiorillo (THOMPSON, 1984). Segundo Carl Flesch (1930), Jacob Dont (1815-1888) compôs uma série de estudos de violino denominada Gradus and Parnasum, na qual ele foi o primeiro a dar uma nova direção à técnica de dedilhado, tirando-a de suas antigas limitações.

Flesch (1930) diz ainda que os estudos de Dont valem a pena ser colocados junto aos de Kreutzer e Rode. Segundo Maurice W. Riley (1980, p. 183), são dois os fatores primordiais para a larga utilização dos estudos de violino pelos alunos de viola: a falta de familiaridade com a literatura escrita especificamente para viola e a crença errônea de que a viola deve ser tocada exatamente como o violino.

Mesmo nos dias de hoje, muitos violinistas ensinam viola, mas as diferenças entre as duas técnicas têm sido mais bem compreendidas e ajustadas (RILEY, 1980, p. 185).

Muitos outros conjuntos de estudos menos conhecidos foram compostos durante o século XIX. Heinrich Ernst Kayser (1815-1888), professor de violino, escreveu diversos estudos de violino que se tornaram padrão, assim como um método de violino.

Em 1886, Elias Howe (1820-1895) escreveu o Original Violin School e incluiu nele uma série de exercícios de arco e estudos com instruções detalhadas de execução. O A Modern School for the Violin, de August Wilhelmj (1845-1908) foi publicado em seis partes com James Brown.

Os Vinte e Quatro Caprichos de Nicolo Paganini (1782-1840) foram compostos durante a primeira década do século XIX, mas não foram publicados até 1820, e, segundo Carl Flesch, sua aparição "traçou novos rumos na escrita dos estudos", fazendo com que se tornassem "o trabalho mais valioso nessa área" (FLESCH, 1930, vol.1 p.114).

Os únicos predecessores desses caprichos, que são utilizados como estudos, são os caprichos de Locatelli e as Matinées de Gaviniès, mas não podem ser comparados (STOLBA, 1968, p. 24). Karl Guhr (1787-1848), violonista, seguiu Paganini em suas viagens, estudou suas técnicas e declarou em seu tratado que a criatividade de Paganini formou essencialmente um novo instrumento (NELSON, 1992, p. 142). 
A maioria das inovações sofre alguma oposição, e Paganini e sua "nova" técnica não foi exceção, mas a "oposição a Paganini foi trivial; violinistas de todos os lugares começaram a expandir e refinar sua técnica sob a influência dos famosos Caprichos, e quando as importantes composições de Paganini surgiram postumamente em 1851, seus desafios tornaram-se o novo degrau da técnica do violino". 119

Em 1894, a viola começou a ser valorizada quando o Conservatório de Paris começou a oferecer o instrumento como instrumento principal, tendo como professor Théophile Laforge (1863-1918). Um dos primeiros graduados com o novo currículo foi Louis Bailly, que foi professor de viola no Curtis Institute of Music de 1925 a 1941 (RILEY, 1980, p. 184).

Logo depois da Segunda Guerra Mundial, muitas universidades incluíram quartetos de cordas residentes em suas dependências, que normalmente incorporava o violista como professor de viola na instituição. A inclusão de violistas nas universidades americanas levaram à elaboração de um novo currículo e à oferta da viola como instrumento principal. Muitas escolas européias fizeram esta modificação na mesma época (RILEY, 1980, p. 185).

A viola teve os mesmos avanços técnicos sofridos pelo violino no século $X X$ e também entrou no caminho para o virtuosismo (BOYDEN; WOODWARD, 1989). A literatura para viola solo e a pedagogia do instrumento continuou a avançar no século XX com os diversos livros de estudo que foram publicados, além das transcrições para o instrumento dos livros mais famosos de violino (RILEY, 1980, p. 185). Diversas teorias foram formuladas para explicar esse fato e deve-se pensar nestas mudanças de maneira metódica e lógica, não importando a razão por trás delas. Livros de estudos mais antigos constituem uma fonte valiosa que demonstra a história dessa transição.

Antoine-Bartholomy Bruni (1751-1821) nasceu na Itália e foi professor, compositor, maestro e instrumentista. No prefácio de seu Méthode ele explica que elimina as instruções normalmente encontradas nos métodos em favor dos estudos, para auxiliar os alunos a familiarizar-se com a clave de dó. Do nível de dificuldade

\footnotetext{
119 “Opposition to Paganini was futile; violinists everywhere began to expand and refine their technique under the influence of the famous Caprices, and when Paganini's important compositions appeared posthumously in 1851, his achievementes became the new plateau of violin technique". New Grove. "Paganini, Nicolo".
} 
técnica, é aparentemente voltado para violistas que são violinistas formados (RILEY, 1980 , p. 180-181).

Similarmente, a Pratische Bratschenschule de Brämig omite considerações técnicas elementares, presumindo que foram tratadas anteriormente no violino (NELSON,1992, p. 192).

Em 1897, H. Klingenfeld escreveu um método intitulado Viola School for Violin Players, no qual ele defende o estudo da viola e do violino simultaneamente pelo fato de o estudo da viola aperfeiçoar a técnica do violino (NELSON, 1992). Robert Dolejsí, por outro lado, acreditava que a melhor forma de desenvolvimento poderia ser alcançada em um ou outro instrumento, mas não em ambos, já que o desenvolvimento das qualidades técnicas em um instrumento trabalha diretamente contra os princípios exigidos para a excelência no outro (DOLEJSI, 1939, p. 1).

Dolejsí inicia sua descrição da maneira de tocar viola explicando que é imensamente diferente da maneira de tocar violino (DOLEJSI, 1939). Primrose (1988) dizia que o que é bom para o violista é bom para o violinista, mas o contrário não necessariamente é verdade (DALTON, 1988, p. 38).

Um dos obstáculos iniciais que os violinistas encontram quando tocam viola é a clave de dó. Primrose (1988) recomenda a utilização dos estudos em diversas posições para facilitar a leitura. Em primeiro lugar, estudos mais fáceis podem ser utilizados até que a leitura na clave de dó seja fluente. A transposição pode ser útil em primeiro lugar, mas para que o progresso seja mais eficiente, é preferível ler ao invés de transpor.

O tamanho da viola é outro empecilho para os violinistas que tocam viola. Não somente o corpo do instrumento é mais longo, mais pesado e mais largo que o do violino, o braço e as cordas são mais grossos, o que exige uma técnica diferente da que é exigida no violino. Segundo Galamian (1966, p. 1 e 12):

A relação do instrumento com o corpo, braços e mãos tem de ser uma que permita uma execução confortável e eficiente de todos os movimentos exigidos para tocar. Este é, em última análise, o critério principal para a 'exatidão' de qualquer atitude corporal ou de qualquer ação muscular" porque "somente o que é natural é confortável e eficiente. ${ }^{120}$

\footnotetext{
120 "The relationship of the instrument to the body, arms, and hands has to be one that Will allow a comfortable and efficient execution of all playing movements. This is, in the last analysis, the mais criterion for the 'rightness' of any bodily attitude or any muscular action" "only what is natural is comfortable and efficient".
} 
Todos os três fatores principais na produção de som mencionados por Galamian (velocidade do arco, pressão e ponto de contato) necessitam um ajuste cuidadoso ao trocar de um instrumento para o outro, particularmente quando a mudança é do violino para a viola (GALAMIAN, 1966, p. 55). Se tocada como um violino, o som produzido pela viola é superficial, tipo flautato, insatisfatório (BARRET, 1978, p. 60). Para "atingir as profundezas de seu instrumento ao invés de flutuar na superfície", mais peso deve ser aplicado com o arco, e o peso da mão esquerda deve ser adequado em relação às cordas mais longas e largas (DOLEJSI, 1939, p.1).

Dolejsí (1939) recomenda a utilização de estudos concentrados na distribuição de arco, disposição e ponto de contato para auxiliar na produção de sons mais ricos e profundos na viola, como por exemplo o Kreutzer n.1, Fiorilo n.2 ou Campagnoli n.6. O instrumento também soa mais se o som é produzido corretamente (GALAMIAN, 1966, p. 10).

Os estudos têm sido utilizados para o aperfeiçoamento da técnica por muitos anos, e suas formas e estilos variam de acordo com o compositor e a época em que foram escritos. Para alguns compositores, o foco principal é o aperfeiçoamento da técnica, e uma pequena consideração é dada a outros fatores. Outros pensam em seus estudos como composições completas, com nuances musicais e desafios técnicos.

Apesar do progresso que houve na técnica e no repertório da viola, ainda é depositada uma confiança grande no material pedagógico dos violinistas. Praticamente desde 0 início os violistas utilizam estudos de violino para 0 aperfeiçoamento da técnica, e enquanto isso era necessário a princípio, a tradição continua por opção.

Se os violistas costumavam ser músicos inferiores, as modificações do repertório e da técnica no século $X X$ criou um padrão mais alto de performance. Ao subir o padrão, os violistas foram obrigados a utilizar os estudos para violino para atingir o domínio técnico que eles exigiam.

Entretanto, a aceitação e utilização dos estudos de violino não é efetuada sem considerações. Deve ser acompanhada pela consciência e pelas sutilezas que fazem a viola diferente do violino, e essas diferenças devem ser exploradas e cultivadas. 
A utilização de métodos escritos originalmente para violino no ensino da viola tem uma explicação plausível na falta de conhecimento já enraizada pela tradição. Para compreender isso, é útil examinar a história da pedagogia da viola.

No período Barroco, os violistas eram, a princípio, violinistas. Segundo Judy Tarling (2001, p. 230), provavelmente era prática na época: "como a viola pode ser considerada como um violino grande, tocada basicamente com a mesma técnica, é como a maioria dos violinistas tenham tocado a viola naturalmente, como e quando requisitados" ${ }^{\prime 21}$.

Muitos violinistas que tocavam viola não eram muito bons, e os violinistas mais talentosos não eram convencidos a tocar viola. Segundo Johann Joachim Quantz (1697-1773), respeitado músico e compositor do período Barroco:

\begin{abstract}
A viola é comumente considerada de pequena importância no meio musical. A razão pode ser que é frequentemente tocada por pessoas que ou ainda são iniciantes no conjunto ou não possuem dons particulares para se destacar no violino, ou o instrumento oferece tão poucas vantagens aos seus instrumentistas que as pessoas habilidosas não são facilmente persuadidas a tocá-lo. ${ }^{122}$ (QUANTZ, 1985, p. 237).
\end{abstract}

Quantz (1985) não especifica quais são as tão poucas vantagens, mas em uma época em que o violino estava emergindo como instrumento solo virtuosístico, a viola, com seu papel de voz subserviente, permaneceu à sombra do violino. Isso é evidenciado pelo "estado lamentável do repertório de viola em meados do século XVIII" (TARLING, 2001).

O Concerto de Brandenburgo de Bach, BWV 1051, e o Concerto de Telemann em sol maior são as duas únicas obras significativas escritas para viola nesse período (TARLING, 2001).

Igualmente relevante é a escassez de livros de técnica ou de métodos para viola nesse período. Violistas não tinham fontes para estudo. Por comparação, diversos métodos para violino foram editados desde o início do século XVIII, assim como tratados de importância, como Michel Corette (1741), Francesco Geminiani

\footnotetext{
121 "as the viola may be regarded as a large violin, played with basically the same technique, it is likely most violinists would have played the viola as a matter of course, as and when they were required to do so"

${ }^{122}$ The viola is commonly regarded as of a little importance in the musical establishment. The reason may well be that it is often played by persons Who are either still beginners in the ensemble or have no particular gifts with which to distinguish themselves on the violin, or that the instrument yields all too few advantagesto its players, so that able people are not easily persuaded to take it up."
} 
(1751), Leopold Mozart (1756) e L’Abbé (1761). Segundo Riley (1993, p. 167), o contraste é explicado:

\begin{abstract}
A publicação de um livro de instruções para um instrumento resulta da necessidade e da existência de um mercado em potencial para a venda desse livro. Na Alemanha, diversas publicações no final do século XVII e no início do XVIII forneceram um material escasso para performance na viola. Os livros alemães normalmente davam as afinações para o alto e para o tenor e davam a entender que eram tocados como o violino... Não havia livros de instruções efetivas para a viola.
\end{abstract}

O primeiro tratado sobre a viola surgiu somente em 1782, o Methode d'Alto, por Michel Corette. Com a maior proeminência adquirida do instrumento nas partes de ópera, obras sinfônicas e quartetos de cordas durante os séculos dezoito e dezenove, mais métodos de viola começaram a surgir, como os escritos por Bartolomeo Bruni (1805), Franz Anton Hoffmeister (c.1800) e Bartolomeo Campagnoli (c.1805). Mas a maioria deles não era muito conhecida, ou não estava disponível, e tratam a viola de maneira muito similar ao violino.

Pouca ou nenhuma referência foi feita às diferenças entre os dois instrumentos, e qualquer comentário normalmente feito tratava somente sobre a afinação das cordas da viola ou da leitura da clave de dó. ${ }^{123}$ Riley destaca o fato de que a maioria dos ensinamentos de viola do século XIX era efetuada por violinistas que transpunham estudos de Rudolphe Kreutzer, Jacques Féréol Mazas e outros para a viola. Até mesmo o Conservatório de Paris tratava a viola como nada mais que um instrumento secundário de estudo, o que Hector Berlioz (1803-1869) apud Riley (1980, p. 184) condenava em meados do século XIX:

É lamentável que não haja classe especial de viola. Esse instrumento, apesar de sua relação com o violino, necessita de estudo individual e prática constante para que seja tocado apropriadamente. É um preconceito antigo, deplorável e absurdo que até agora tenha sido legado as performances da parte do tenor para violinistas de segunda - ou terceira - categoria. Sempre que um violinista é medíocre, dizem "Ele será um ótimo tenor". Do ponto de vista da música moderna é falso o pensamento de que partes sem valor não são mais escritas para orquestra (pelo menos pelos

\footnotetext{
${ }^{123}$ Logicamente isso não quer dizer que esses estudos não têm valor pedagógico. Entretanto, para serem eficazes no auxílio ao violista ou ao violinista que passa a tocar viola, devem ser utilizados de maneira dirigida, com o professor apontando os objetivos.
} 
grandes mestres) [...] e a condição de inferioridade de uma parte com relação a outra não é reconhecida. ${ }^{124}$

Em 1894, o Conservatório finalmente estabeleceu a viola como instrumento principal e, pouco depois, a Eastman School of Music em Rochester, Nova lorque, e o Curtis Institute of Music em Philadelphia, Pennsylvania. Entretanto, foi após a Segunda Guerra Mundial que outras escolas nos Estados Unidos e Europa começaram a estabelecer a viola como instrumento principal e contratar professores de viola "que eram familiarizados com os problemas de performance peculiares ao instrumento" (RILEY, 1980, p. 185).

Quando a viola começou a progredir nas instituições educacionais como instrumento principal no início do século $X X$, a idéia da viola como instrumento solista começou a ganhar popularidade sob a influência pioneira de Lionel Tertis e, mais tarde, do virtuoso William Primrose. Através desses esforços incansáveis de promover 0 instrumento e seu alto padrão em performances, assim como 0 surgimento de novas obras para o instrumento, a viola começou a estabelecer sua identidade desassociada do violino. Segundo Kubala (2009):

Também no século $X X$ ocorreu uma transformação na maneira de lidar com as possibilidades timbrísticas da viola. Em grande parte influenciados por Hindemith ${ }^{125}$ (1895-1963), compositores passaram gradualmente a valorizar o emprego de todo o espectro sonoro da viola [...] Foi um salto significativo para a evolução de uma escrita mais rica em elementos idiomáticos para o instrumento, tendo sido, de certa forma, a emancipação do jugo da comparação com o violino (KUBALA, 2009, p.98).

Nesse contexto histórico, pode-se perceber facilmente que no passado a viola era tida como nada mais do que um violino grande ou um instrumento secundário.

Parte do problema se deve ao fato de que hoje existe mais acesso à instrução especializada na viola, mas essa instrução ainda não é sempre buscada. Atualmente é maior a consciência de que existem diferenças entre violino e viola.

\footnotetext{
124 "It is to be regretted that there is no special class for the Viola. This instrument, notwithstanding its relation to the violin, needs individual study and constant practice if it is to be properly played. It is na antique, absurd, and deplorableprejudice that has hitherto handed over the performance of the tenorpart to second-or third-rate violinists. Whenever a violinist is mediocre, it is Said, "He Will make a capital tenor." From the stand-point of modern music this is false reasoning, for trashy pars are no longer written for the orchestra (at least by the great masters)... and a condition of inferiority in any one part with regard to any other is not recognised."

${ }^{125}$ Violista e compositor alemão, soube explorar o timbre da viola em todos os seus registros, sendo um dos compositores pioneiros na valorização do instrumento como timbricamente independente.
} 
O desenvolvimento da pedagogia da viola desde o início do século $X X$ contribuiu para o aumento dessa consciência. Instrumentistas e pedagogos especializados na viola, como William Primrose (1904-1982) e Karen Tuttle (19202010), hoje têm alunos no corpo docente de instituições musicais em todo o mundo, ensinando viola como instrumento principal.

Houve também um modesto aumento na literatura de métodos específicos de transição de violino para viola. O Viola School for Violin Players de Heinrich Klingenfeld foi o primeiro método escrito para violinistas que passam a tocar viola. Outros métodos incluem From Violin to Viola: A Transitional Method, de Paul Harvey Whistler, publicado em 1947. Foram também publicados artigos sobre o assunto por professores como Juliet White-Smith, atualmente professora de viola da Universidade de Colorado.

Todas as fontes mencionadas acima contêm aspectos pedagógicos positivos e negativos, e são úteis em vários níveis ao despertar a consciência das diferenças de técnica e conceitos de sonoridade entre o violino e a viola. O método de Whister é rudimentar na maioria dos exercícios e exemplos oferecidos, e explora apenas basicamente a sonoridade e a técnica da viola. O método de Klingenfeld é limitado, enfocando somente a leitura da clave de dó e escalas. Os métodos não são tão detalhados em suas descrições sobre a sonoridade e as diferenças técnicas entre violino e viola.

O artigo escrito por White-Smith está entre as fontes mais importantes, fornecendo informações em assuntos da viola, como conselhos práticos para o desenvolvimento do conceito do som da viola e exercícios básicos para desenvolvêlos. Seu artigo também oferece referências de outras fontes pertinentes. 


\section{CONCLUSÃO}

A família do violino surgiu no Renascimento e este instrumento foi desenvolvido e aperfeiçoado em toda a sua capacidade e potencialidade, enquanto somente no século $\mathrm{XX}$ a viola teve seu despertar, passando a ser um instrumento representativo de uma nova linguagem estética e expressiva.

Como pudemos verificar, a viola é um instrumento fundamentalmente diferente do violino. Sua acústica singular e suas propriedades físicas têm implicações importantes na produção do som e técnica.

Para obter todo o potencial sonoro da viola, é importante que o violista trabalhe a consciência e a compreensão da sonoridade, particularmente em três áreas: caráter, foco e clareza. Uma vez que o violista tenha desenvolvido um claro conceito desses três aspectos, ele pode explorar os ajustes da técnica de mão direita e esquerda do violino.

A maioria destes ajustes ocorre na mão direita, tratando da necessidade de aumentar a energia utilizada para fazer o instrumento e as cordas soarem. Há também alguns ajustes importantes de mão esquerda, que afetam a afinação e o caráter sonoro.

A viola tem se caracterizado através da história como um instrumento lânguido, triste e opaco, mas também possui sonoridade nobre, suave e profunda. Desta maneira, a viola adquiriu um valor estético e artístico particular na atualidade. Estas características foram reconhecidas e aceitas hoje e, como conseqüência, se desenvolveu como um instrumento independente dentro de sua família.

Houve mudanças radicais, como o desenvolvimento de novos intérpretes especialistas, o que permitiu a multiplicação de composições para o instrumento, que abordam suas particularidades expressivas, independente do violino.

Do mesmo modo se deu a especialização do ensino da viola, com uma escola com características próprias, assim, o instrumentista alcançou um grau de profissionalismo como de qualquer outro instrumento, e não como um violinista que toca viola.

Apesar de toda essa evolução, estudos compostos originalmente para violino ainda são utilizados para o estudo da viola, hoje com a devida consciência e 
atenção voltada para as sutis diferenças existentes nas técnicas dos dois instrumentos, valorizando assim o potencial sonoro e técnico da viola. 


\section{REFERÊNCIAS BIBLIOGRÁFICAS}

AUER, Leopold. Violin Playing as I teach It. Londres: Gerald Duckworth, 1921

BARRETT, Henry, The Viola: Complete Guide for Teachers and Students, $2^{\text {nd }}$ ed. Rev. ed. Tuscaloosa: The University of Alabama Press, 1978

BEAMENT, James, The Violin Explained: Components, Mechanism, and Sound. Oxford: Claredon, 1977.

BERLIOZ, Hector, Treatise on Orchestration. New York: Kalmus, 1948

BOYDEN, David. History of Violin Playing. London: Macmillan. 1989

BOYDEN, D. Introdução de The Art of Playing the Violin, de Geminiani. London: Oxford University, 1952

Violin, The New Grove's Dictionary of Music and Musicians

Collection. London: Ed. Stanley Sadie, Macmillan, 1980

BOYDEN, D. e WOODWARD, A. "The Viola" em Violin Family, Ed. Stanley Sadie. The Grove Musical Instrument Series. New York: Norton. 1989

DALTON, David. Playing the Viola - Conversations with William Primrose. New York: Oxford University, 2003;

DOLEJSí, R. Modern viola technique. Chicago: University of Chicago, 1939.

DOUNIS, D. C. The Dounis collection. New York: Carl Fischer, 2005. 1941 and 1943.

Specific technical exercises for viola, Op.25. New York: Carl Fischer, . The artist technique of violin playing, Op.12. New York: Carl Fischer, 1921.

FLESCH, Carl. The Art of Violin Playing. 2 vol. Nova lorque: Carl Fischer, 1930

GALAMIAN, Ivan and NEUMANN, Frederick, $C$ ontemporary Violin Technique, 2 vol. New York: Galaxy Music,1966

GALAMIAN, Ivan. Principles of Violin Playing and Teaching. Englewood Cliffs, New Jersey: Prentice Hall, 1962;

GEMINIANI, Francesco. The Art of Playing the Violin. London: J. Johnson, 1751 
MENUHIN, Yehud e PRIMROSE, William. Violin and Viola. Yehudi Menuhin Music Guides. London: Kahn \& Averill, 2008

MOZART, L. A Treatise on the Fundamental Principles of Violin Playing. Translated by Editha Knocker. 2nd Edition. Oxford: Oxford University. 1951.

NELSON, Sheila M. The Violin and Viola: History, Structure, Techniques. Nova lorque: Dover Publications, 2003;

PRIMROSE, William. A Walk in the North Side: Memoirs of a Violist. Provo, Utah: Brigham Young University, 1978

QUANTZ, Joahnn J. and Reilly, Edward. On playing the Flute. UPNE, 2nd edition, 1985

RIDGEN, John S., Physics and the Sound of Music, 2ed. New York: John Wiley \& Sons, 1985

RILEY Maurice. The History of the Viola. 2 vol. Michigan:Braun-Brumfield.1980-1991 The history of the viola. v. 1. $2^{\text {nd }}$ ed. Ann Arbor/USA: Braun-Brumfeld, 1993.

SADIE, S. The grove musical instrument series. The Violin Familiy. David Boyden \& Ann Woodward. New York: Norton, 1989.

STOLBA, K. M. A history of the violin etude to about 1800. Fort Hays: Fort Hays Kansas Stte College, 1968. (New Series, Music Series, n. 3).

STOWELL, Robin; The Early Violin and Viola - A Practical Guide. Cambridge: Cambridge University, 2001

TARLING, J. Barroque string playing for ingenuous learner. $2^{\text {nd }}$ ed. Hertfordshire: Corda Music Publications, 2001.

WHISTLER, H. S. From violin to viola: a transitional method. Chicago: Rubank, 1957.

\section{$\underline{\text { Artigos }}$}

DONOSO, J. P. [et al] Acústica do violino: física e musicologia. Revista Ciência Hoje. v. 45, n. 267, janeiro/fevereiro, 2010.

$\overline{2305(2008) \text {. }}$

A física do violino. Revista Brasileira de Ensino de Física. v. 30, n. 2,

MOSER, A. Die violin skordatur. Archiv für Musikwissenschaft, 1. Jahrg., H. 4. jul., 1919, p. 573-589.

RUSSEL, T. The violin scordatura. The Musical Quarterly, XXIV, 1938. 
WHITE-SMITH, J. From violin to viola. American String Teacher Magazine, feb. 2000.

\section{$\underline{\text { Sites }}$}

BOYDEN David, [et al]. Scordatura. Grove music online. Oxford music online. Disponível em:

http://www.oxfordmusiconline.com/subscriber/article/grove/music/41698, acesso em: 10/11/2010.

. Viola. Grove music online. Oxford music online. Disponível em: http://www.oxfordmusiconline.com:80/subscriber/article/grove/music/29438, acesso em: 10/11/2010.

. Violin. Grove music online. Oxford music online. Disponível em: http://www.oxfordmusiconline.com:80/subscriber/article/grove/music/41161, acesso em: 10/11/2010.

BRUSSIERE, Atelier la. Disponível em:<http://www.atelierlabussiere.com/pcom4.htm>, acesso em: 19/09/2010.

DAVIS, W. Physics and astronomy online. Disponível em: http://www.physlink.com/Education/AskExperts/ae165.cfm, acesso em: 26/03/2010.

WOODHOUSE, J. Acoustics, \$Il: string instruments. Oxford music online. Disponível em: http://www.grovemusiconline.com, acesso em: 02/03/2010.

http://imslp.org/wiki/Don_Quixote,_Op.35_(Strauss,_Richard). Acessado em 07 julho 2010

\section{Dissertações e Teses}

CHAMBERS, M. The 'mistuned' cello: precursors to J.S. Bach's suite $V$ in $C$ minor for unaccompanied violoncello. USA: The Florida State University, 1996. (Tese de Doutorado).

DANE, M. Coordinate effort: a study ok Karen Tuttle's influence on modern viola teaching. USA: Rice University, 2002. (Tese de Mestrado).

KUBALA, R. L. O concerto para viola e orquestra de Antônio Borges Cunha: a obra e uma interpretação. Campinas: UNICAMP, 2009. (Tese de Doutorado).

A escrita para viola nas sonatas com piano Op.11 №4 e Op.25 №4 de Paul Hindemith: aspectos idiomáticos, estilísticos e interpretativos. Campinas: UNICAMP, 2004. (Dissertação de Mestrado). 
RODRIGUES, T. C. Ao gosto de II Foribondo: um estudo das Seis Sonates Pour Le Violoncelle Et Basse Continue de Francesco Geminiani segundo seus estudos e transcrições. São Paulo: UNICAMP, 2009. (Dissertação de Mestrado).

TOPPER, M. A. Correting the right hand bow position for the student violinist and violist. USA: The Florida State University, 2002. (Tese de Doutorado).

WECHSBERG. J. The glory of the violin. New York: The Viking Press, Inc. 1972.

\section{$\underline{\text { Partituras }}$}

BACH, J. S. Editado por Simon Rowland-Jones. Six Suites for Solo Violoncello, Edition for Solo Viola. BWV 1001. London: Hinrichsen, Peters, 1998.

CAMPAGNOLI, Bartolomeo. 41 Capricci. Op.22 per Viola. Angelo Consolini. Milano: Ricordi.1954.

1958.

41 Caprices. New Yourk: International Music Company,

DANCLA, Charles. 20 Etudes Brillantes et Charectéristiques. Budapest: Editio Musica, 1980.

DOLEJSÍ, Robert. Modern Viola Technique. Chicago:University of Chicago, 1939

DONT, Jacob. Etüden und Capricen Op.35.Bearbeit für Viola von Max Rostal. Schott.

DOUNIS, D.C. Specific Technical Exercises for Viola, Op.25. New York: Carl Fischer, Inc. 1941 and 1943

Fischer, Inc. 1921.

. The Artist Technique of Violin Playing, Op.12. New York: Carl

. The Dounis Collection. New York: Carl Fischer. 2005

FIORILLO, Federigo. 31 Selected Studies. New York: International Music Company, 1965.

.31 Studies for Viola Solo. Transcribed by Louis Pagels. New York: International Music Company

FLESCH, Carl. Basic Studies for Viola. New York: Carl Fiscer, Inc., 1990.

Berlin: Ries \& Erler. 1956

Das Scale System. Bearbeit für Viola von Charlotte Karman. 
GAVINIÈS, Pierre. Les 24 Matinées per viola. Transcrizione Michelangelo Abado. Milano: Ricordi. 1957

KAYSER, H.E. 36 Studies. New York: International Music Company, 1970.

KIEVMAN, Louis. Practicing the Viola Mentally-Phisically. California: Kelton Publications. 1969

KREUTZER, Rodolphe. Fourth-Two Estudies. New York: International Music Company, 1963;

1987 . 42 Studies or Caprices: Violin Method. New York: Schirmer. . 42 Studies or Caprices Transcribed for the Viola by Walter Blumenau. New York: Schirmer. 1950

LIGETI, György. Sonate for Viola Solo. Mainz: Schott, 2001

MAZAS, Etudes Speciales. Op.36, Book 1 for Viola Solo. Transcribed by Louis Pagels. New York: International Music Company.

MAZAS, Etudes Brillantes. Op.36, Book 2 for Viola Solo. Transcribed by Louis Pagels. New York: International Music Company.

MOZART, W.A. Sinfonia Concertante for Violin and Viola K,320d.Milwaukee: Schirmer

RODE, Pierre. 24 Caprices for the Viola. Transcribed by Louis Pagels. Melville: Belwin Mills

RODE, Pierre. 24 Caprices. New York: International Music Company SCHRADIECK, Henry. The School of Violin-Technics. New York: Schirmer, Inc. 1951 SEVCIK,Otákar. Op.1. Bryn Mawr, Pa: Elkan-Vogel Inc. 1946 lorque: Bosworth, 1956 Op.2 Part 1 School of Bowing Technique. Ed. Lionel Tertis. Nova . Op.2 Part 2 School of Bowing Technique. Ed. Lionel Tertis. Nova lorque: Bosworth, 1956

. Op.3 School of Bowing Technique. Ed. Margaret Major. Nova Iorque: Bosworth, 1984 . Op.8. New York: Schirmer, Inc. 1950

Presser Company. Op.8 Shifting. Transcribed for Viola by Max Aronoff. Theodore 


\section{ANEXO A - ANÁLISE DE LIVROS ESPECÍFICOS}

Nos últimos anos, foram publicados diversos métodos e livros para estudo que, devido à sua larga utilização, tornaram-se padrão na pedagogia dos instrumentos de cordas. "Até cerca de cinquenta anos atrás, o violinista iniciante tinha seu curso baseado em uma das inúmeras escolas de violino, mais tarde complementadas pelos materiais de estudo habituais (Kayser, Kreutzer, Gaviniès, Fiorillo, Rode)." (FLESCH, 1930. V.1 p.3). Muitos livros de autores como Hofmann, Kayser, Bruni, Wohfhart, Campagnoli, Fiorillo, Kreutzer, Rode e Gavineès abrangem todos os elementos da técnica e são considerados padrões, segundo Stolba (1968, p.233). Há diversos pontos em comum nesses livros citados por Stolba, mas há também características que separam uns dos outros. Através de um estudo detalhado, é possível identificar essas características e a decisão sobre que livro escolher para qual situação torna-se menos difícil.

\section{H. E. Kayser - 36 Estudos op.20}

Heinrich Ernst Kayser (1815-1888) foi professor de violino e violinista em Hamburgo, e compôs inúmeros estudos, além de um método completo para violino. Seus 36 Estudos foram elaborados para um aluno de nível intermediário e abrange uma grande faixa de exercícios para mão direita e esquerda, geralmente permanecendo nas posições mais baixas (BARRETT, 1978, p.13). Escalas e arpejos são utilizados extensivamente no livro. Um aspecto musical interessante é a utilização da fórmula de compasso 5/4 no estudo número 17. A maioria dos estudos combina exercícios para mão direita e esquerda, mas alguns focam especificamente uma ou outra.

Jacques-Féréol Mazas - Etudes Spéciales, Etudes Brillantes e Etudes d'Artistes

Jacques-Féréol Mazas (1782-1849) compôs diversos estudos e um método para viola. Seus estudos para violino foram publicados em três volumes: Suite I, entitulado Etudes Spéciales, contendo 30 estudos, Suite II, denominado Etudes Brillantes, contendo 27 estudos e Suite III, entitulado Etudes d'Artistes, contendo 18 estudos (STOLBA, 1968, p.247). A música de Mazas foi moderna em sua época e 
seus estudos são ainda hoje frequentemente utilizados. No início de cada um de seus estudos são dadas instruções - "Melodie", "Pathétique", "Tarantelle", "Portamento", por exemplo, mas são omitidas nos estudos que focam no estilo e expressão (STOLBA, 1968, p.247).

Barrettt classifica os estudos de Mazas como nível seis, e, apesar de existir algumas combinações de mão direita e de mão esquerda, a maioria foca em uma ou outra. A ênfase está entre a primeira e terceira posições, apesar de algumas vezes haver a utilização de posições mais altas, e as cordas duplas são encontradas em geral somente nas cadências. Há alguma musicalidade nesses estudos, a maior preocupação é com o domínio técnico, mais que com a expressão musical.

Rodolphe Kreutzer - 42 Studies

Os estudos de Keutzer surgiram inicialmente em 1796, publicados pelo Conservatório de Paris (NEW GROVE, "Kreutzer, Rodolphe”). A publicação original incluía quarenta e dois estudos, dois dos quais provavelmente não foram compostos por Kreutzer (STOLBA, 1968, p.243).

Stolba cita sua aparição pouco antes de 1800, mas não dá uma data específica. A edição de setembro de 1800 do Intelligenz-Blatt no Allgemeine musikalische Zeitung cita uma recente publicação de Breitkopf and Härtel que se acreditava ser dos estudos de Kreutzer (STOLBA, 1968, p.243). Como escreveu David Charlton, "Devido à sua abordagem e musicalidade fundamental, editores consecutivamente tem modernizado os 42 Estudos adicionando novos dedilhados e arcadas ou compondo suas próprias variantes." "126 (NEW GROVE, "Kreutzer, Rodolphe)

Barrettt classifica os estudos de Kreutzer como nível 7, correspondendo ao início da prática das escalas em terças, sextas e oitavas (BARRETT, 1978, p.23). Kreutzer utiliza algumas técnicas avançadas, mas primeiramente em uma escala limitada. Elementos técnicos são geralmente isolados e praticados um por vez. Há alguns estudos que combinam diversos elementos, mas são exceção. Segundo David Charlton, os estudos de Kreutzer contêm os "desafios do violino moderno ao concentrar de certa forma a fluência na contração e extensão da mão

\footnotetext{
126 "Owing to their fundamental musicality and approach, successive editors have brought the 42 Studies up to date either by adding new fingerings and bowings or by composing their owin variants".
} 
esquerda"127 (DALTON, 2003, p.23). Existem diversos estudos com arcadas e ritmos associados que podem ser aplicados a diversos estudos. Stolba adverte que enquanto as variações de arcadas podem ser utilizadas, também podem tornar-se entediantes e transformar o estudo em um exercício (STOLBA, 1968, p.243).

Primrose se referiu aos estudos de Kreutzer como "impressionantemente musicais", enquanto que, musicalmente, segundo Stolba, estão abaixo dos de Gaviniès, Rode e Fiorillo (STOLBA, 1968, p.247). São muito poucos os estudos com qualquer indicação de dinâmica, e muitos deles iniciam com uma marcação de dinâmica que é a única encontrada durante o estudo todo. Adicionar dinâmica aumenta o nível de dificuldade e auxiliará na prevenção do toque mecânico como elementos técnicos indicados.

\section{Federigo Fiorillo - 31 Selected Studies}

Federigo Fiorillo (1755-1823) foi um compositor profícuo - cerca de duzentas obras são atribuídas a ele, mas é mais conhecido por seus estudos. Há poucos registros escritos de que ele foi professor, ao invés disso ele passava a maioria do seu tempo tocando bandolim e viola (STOLBA, 1968, p.238). Apesar disso, seus estudos revelam seu conhecimento das dificuldades de performance do violino, e conquistaram uma posição ao lado de Kreutzer e Rode na literatura pedagógica do violino e da viola (STOLBA, 1968, p.238).

Os estudos de Fiorillo estão classificados como nível oito. Enquanto são ligeiramente mais fáceis que os de Campagnoli, eles possuem uma grande abrangência de técnicas, e elementos de mão esquerda e direita são frequentemente combinados ao invés de serem isolados. O trabalho em ítens como cordas duplas, oitavas, escalas e arpejos, além da utilização de posições altas, fazem com que os estudos de Fiorillo sejam uma ponte entre Kreutzer e Rode. Como nos estudos de Kreutzer, Fiorillo propõe variações de arcadas para dois de seus estudos que podem ser aplicados a diversos outros. Há alguns estudos específicos para mão direita, alguns outros para mão esquerda, mas a maioria incorpora dificuldades para ambas as mãos.

Stolba expressou sua boa impressão com a musicalidade dos estudos de Fiorillo dizendo que "estes são estudos para estilo e expressão assim como são

\footnotetext{
127“challenge of the modern violin by aiming partly at fluency in contraction and extension of the left hand".
} 
estudos para técnica."128 (STOLBA, 1968, p.236). Indicações de dinâmica são freqüentes, e diversos estudos contêm material melódico interessante.

Pierre Rode - 24 Caprices

Jacques Pierre Rode (1774-1830) compôs um conjunto de caprichos destinados a alunos avançados, como os estudos de Fiorillo e Gaviniès. Segundo Boris Schwarz, "Seu talento inato como professor é demonstrado em seus 24 Caprichos, que equilibram as necessidades técnicas e musicais do aluno e tornaramse parte indispensável do currículo do violinista". (NEW GROVE, "Rode, Jacques Pierre). Sheila Nelson concorda com essa afirmação em seu livro The Violin and Viola, dizendo que assim como os estudos de Kreutzer, os caprichos de Rode são essenciais ao desenvolvimento técnico dos alunos hoje em dia (NELSON, 2003 p.138).

Assim como os estudos de Fiorillo, os caprichos de Rode são classificados como nível oito, e o material contido neles é mais uniformemente equilibrado entre mão esquerda, mão direita e a combinação dos estudos que a maioria dos livros de estudos (BARRETT, 1978, p.23). As dificuldades trabalhadas são essencialmente as mesmas que as encontradas nos estudos de Fiorillo e Gaviniès, mas os estudos de Rode são mais musicais que ambos (STOLBA, 1968, p.245). O tamanho dos estudos varia, as melodias são agradáveis, os movimentos harmônicos são interessantes e cada estudo é uma peça satisfatória. Os estudos de Rode abrangem também todas as tonalidades maiores e menores, o que é raro, e apesar de serem em sua maioria monofônicos, há algumas cordas duplas e acordes (STOLBA, 1968, p.245).

\section{Pierre Gaviniès - 24 Studies}

Pierre Gaviniès (1728-1800) foi um violinista, compositor, professor e filantropo francês que compôs um conjunto de vinte e quatro estudos para violino (Les 24 Matinées), que demonstram sua virtuosidade pelo seu nível de dificuldade. Ele tocava frequentemente no Concert Spirituel, como solista e músico de câmara, e após o surgimento do Conservatório de Paris, ele aceitou um cargo como professor de violino, no qual permaneceu até sua morte (NEW GROVE, "Gaviniès, Pierre").

\footnotetext{
128،"these are études for style and expression as well as études for technique."
} 
Segundo Stolba, "Gaviniès planejou seus estudos para o aperfeiçoamento da mecânica da mão esquerda e da flexibilidade do arco." ${ }^{\prime 29}$ (STOLBA, 1968, p.240) Barrett classifica os estudos de Gaviniès como nível dez, o que é apropriado, considerando o alto nível de técnica que eles exigem (BARRETT, 1978, p.27). Há passagens em posições altas em todas as quatro cordas (Stolba destaca sua preferência pela quarta e sétima posição), tonalidades complexas (muitas são menores) e componentes difíceis para mão esquerda e direita são combinados ao invés de isolados, como nos livros de estudos mais fáceis (STOLBA, 1968, p.240). Os saltos e extensões encontrados em seus estudos são mais complicados na viola, considerando a diferença de tamanho entre o violino e a viola, e os estudos de Gaviniès são mais utilizados para o refinamento do que para o ensino da técnica. Um alto nível de proficiência é pré-requisito para estes estudos, e enquanto há alguns que focam especificamente nas dificuldades de mão esquerda ou direita, a maioria apresenta as dificuldades para as duas mãos ao mesmo tempo.

Os 24 Studies de Gaviniès são moderadamente musicais, apesar da extensa utilização de padrões repetidos e uma pequena variação dos padrões estabelecidos no primeiro compasso. Indicações de dinâmica são reservadas quase que exclusivamente para o primeiro compasso, e somente nos estudos número 3 e 12 há outra indicação que não "forte".

A utilização de estudos como parte regular do ensino fornece ao aluno as qualidades técnicas que eles necessitam para o sucesso, e pela escolha cuidadosa de estudos que sejam musicais ou ao fazer ajustes para torná-los mais musicais, seu senso de musicalidade é desenvolvido. Ambos os elementos são essenciais, negligenciar um em favor do outro pode ser prejudicial em qualquer nível.

Alguns dos livros analisados terão seus estudos listados abaixo, de acordo com a dificuldade técnica principal a ser trabalhada. Para esta finalidade, dos estudos de Mazas serão somente utilizados os do segundo volume - Etudes Brillantes.Os números referem-se ao número do estudo em cada método.

\footnotetext{
129 "Gaviniès designed his studies for perfection of the mechanics of left hand and suppleness of the bow".
} 
- Arpejos: Kayser 7, 12 e 27, Mazas 37 e 48, Kreutzer 6, 8, 10, 12 e 30, Fiorillo 1, 9, 10, 11, 16, 23, 29 e 30, Rode: 8, 18 e 24, Gaviniès: 6, 9 e 19.

- Controle de Arco: $\quad$ Kayser 2, 3, 6, 7, 11, 16, 17, 21, 26, 28 e 34, Mazas 31, 32, 37, 39, 42, 43, 44, 49, 51 e 53, Kreutzer 1, 13, 14, 25, 27, 28, 29 e 31, Fiorillo $1,5,8,12,15,21,22,25$ e 31, Rode 1, 2, 3, 8, 11, 12 e 13, Gaviniès 1, 2, 5, 5, 8, 11 e 13.

- Cadências: Mazas 40, Kreutzer 23

- Cordas Duplas: Kayser 20, Mazas 46 e 50, Kreutzer 32, 33, 34, 35, 36, 38, 39, 40, 41 e 42, Fiorillo 2, 4, 17, 18, 26 e 30, Rode 4, 19, 20, 23 e 24, Gaviniès 1, 15 e 24

- Independência/Velocidade dos dedos: Kayser 4, 22, 30 e 35, Mazas 54, Kreutzer 9, Fiorillo 28, Rode 9, 10, 16 e 20, Gaviniès 3 e 12

- Forma da mão: Kayser 34, Kreutzer 7, 24 e 25, Fiorillo 5, 13, 22, 24, 27 e 30, Rode: 2 e 19, Gaviniès 4, 5 e 22

- Afinação: Kayser 1, 5, 9, 11, 16, 25, 35 e 36, Mazas 32 e 39, Kreutzer 2, 3, 14 e 26, Fiorillo 15, 23 e 29, Rode 5, 11, 12, 13, 14, 15, 22 e 24, Gaviniès 10, 11 e 13 - Martelé/Detaché: Kayser 1, 9, 11 e 18, Mazas 36, Kreutzer 2, 3 e 5, Fiorillo 29

- Ornamentos: Kayser 14 e 15, Mazas 41, 55 e 56, Kreutzer 15, 16, 17, 18, 19, 20, 21, 22, 31 e 40, Fiorillo 2, 6 e 7, Rode 1, 4 e 16, Gaviniès 1, 7, 15 e 18 - Mudança de Posição: Kayser 32, Mazas 31, 35 e 38, Kreutzer 1, 11 e 26, Fiorillo 13, 14 e 21, Rode 5 e 6, Gaviniès 4, 12, 14, 16, 18 e 21

- Spiccatto: Kayser: 5, 13, 19, 24, 25 e 29, Mazas 45 e 52, Fiorillo 19 e 26, Rode 9, 17 e 21, Gaviniès 4, 14, 16, 18 e 20

- Staccato: Kayser: 23, 31e 33, Mazas 33, 34, 47 e 50, Kreutzer 4 e 28, Fiorillo 3, Rode 7 e 21, Gaviniès 7

- Mudanças de Cordas: Kayser 10, Mazas 49 e 53, Rode 8 e 22, Gaviniès 17, $18,21,22$ e 24 
Bibliografia anotada de Estudos e Métodos originais para Viola $(1780-1860)^{130}$

Bruni, Antonio Bartolomeo (1751-1821) - Methode pour L'AltoContenant lês príncipes de cet instrument Suivis de Vingt-cinq ÉtudesDediée a Monsieur Fabignon

Nascido na Itália, Bruni estudou com Pugnani e passou a maior parte de sua vida adulta em Paris. O método é iniciado com uma breve discussão sobre a clave de do e o dedilhado diatônico na viola. Os primeiros treze estudos são muito pequenos em tamanho, abordam diversos padrões de dedilhados e cordas duplas na viola até a terceira posição. Os dedilhados são extensivamente marcados. A parte principal do método consiste em vinte e cinco estudos, dois dos quais com variações. Variam em tamanho e abordam a maioria dos padrões de dedilhados e cordas duplas nas primeiras três posições. Detaché e staccato são intercalados e as figuras arpejadas são extensivamente utilizadas. Estes estudos são de execução um pouco mais fácil que os estudos de Mazas para violino.

Cavallini, Eugenio (1808-1881) - Guida per lo Studio elementare e progressive della Viola, I e Il parte.

Cavallini foi um violinista, violista e compositor italiano, e aluno de Alessandro Rolla. Foi spalla da Orquestra La Scalla e professor de violino no conservatório. Este método foi escrito em 1860 e publicado postumamente em 1897. A primeira parte deste método é iniciada com cordas soltas e avança até todas as escalas maiores e menores até a quinta posição, com combinações variadas de arcadas. A isso se seguem dezessete exercícios "fáceis", todos curtos e na primeira posição. A maioria da primeira parte consiste em vinte e nove estudos, os primeiros curtos e simples, permanecendo na primeira e terceira posições, e gradualmente torna-se mais longos, mais complexos musical e tecnicamente, e estendendo até a sétima posição. Os últimos estudos exigem habilidades técnicas avançadas. Segunda parte consiste em vinte e quatro estudos em tonalidades menores, e iniciam no nível técnico no qual a primeira parte é finalizada. As habilidades técnicas desenvolvidas incluem sautillé, marcato, staccato com arco para cima, arpejos,

130 Learning Viola Technique Through Original Etudes. ASTA National Conference, Detroit, Michigan. March 8 , 2007. Presented by Steven Kruse, West Virginia University 
cordas duplas, acordes, trinados, mudanças de corda com legato e posições mais altas na corda do.

Giorgeti, Ferdinando (1796-1867) - Metodo per esercitarsi a bem suonare l'alto Viola. Op. 34.

Violinista e compositor italiano, Giorgetti viajou extensivamente pela Espanha e França. Dizem que ele moldou sua maneira de tocar em Rode. Escreveu diversas obras de música de câmara e ensinou violino e viola no Instituto Musicale em Florença. Este método foi escrito em torno de 1840. A primeira parte contém uma breve apresentação da viola e escalas até a quinta posição. As escalas são escritas em duetos para duas violas. A segunda parte, também escrita para duetos, agora para viola e cello, contém exercícios em cordas duplas e seis "Estudos Característicos". Os estudos possuem títulos e foco em técnicas específicas, incluindo sautillé, spiccatto, ornamentos, cordas duplas, mudanças de cordas, mudanças de posição e figuras arpejadas. Todos os estudos exigem um nível técnico avançado. A parte final consiste em uma obra para viola e piano entitulada "Grand Solo for the Viola in the form of a dramatic Scene", que possui uma variedade de exigências técnicas e foi criada para aplicação das técnicas desenvolvidas nas duas partes anteriores.

Kayser, Heinrich Ernst (1815-1888) Neue Schule für Bratsche, Op. 54.

Kayser é mais conhecido por seus Estudos Progressivos e Elementares para violino. O Nouvelle Méthode d'Alto inicia com uma apresentação de ritmos e notações. Os estudos contidos neste método são tecnicamente mais fáceis, menores e não tão musicalmente completos quanto os estudos para violino. Os primeiros quarenta e seis exercícios são todos na primeira posição, enfatizando as técnicas de arco básicas - detaché, staccato e legato, assim como repetições de padrões de dedilhados básicos na mão esquerda. Os exercícios 47 a 49 utilizam a segunda posição e os exercícios 51 a 56 a terceira posição e as mudanças entre primeira e terceira posição. Os últimos quatro exercícios utilizam a quarta e quinta posição e as mudanças entre a primeira e a quinta posição. A obra foi publicada em torno de 1873 em Leipzig, e o opus indica que a publicação foi posterior aos estudos de violino. 
Martinn, Jacques (1775-1836) - Methode d'Alto. Nouvelle Edition ed. Theóphile Laforge.

Jacques Martinn foi um violinista flamengo, que mudou-se para Paris em cerca de 1793 e tocou em diversas orquestras de ópera. Foi professor de violino no Lycée de Charlemagne e escreveu métodos para violino e para viola. A edição editada por Theóphile Laforge, professor de viola do Conservatório de Paris, foi publicada em cerca de 1900. O método está dividido em quatro partes: quatro artigos escritos, entitulados "Princípios", abordando a posição da viola e a leitura da clave de do, doze pequenas lições em forma de dueto de duas violas, que se estendem até a terceira posição e utilizam as técnicas básicas de arco, três sonatas para duas violas, mais longas e com mais desafios técnicos e musicais, sem ultrapassar a terceira posição, e vinte e quatro estudos. Os estudos forma compostos por Cavallini e creditados a ele.

\section{Estudos e Caprichos}

Blumental, Joseph von (1782-1850) - Grand Caprice for Alto, Oeuvre 79.

O violista belga Joseph von Blumenthal estudou música em Praga e exerceu a maioria de sua carreira musical em Viena. A maioria de suas composições é para violino, mas escreveu também um grande número de duos e trios que incluem a viola. O Grand Caprice foi escrito tanto para utilização em concertos como para desenvolvimento técnico. Na tonalidade de fá maior, as arcadas estão todas marcadas e os dedilhados indicados nas passagens cromáticas e nas posições mais altas. Estruturalmente, a obra consiste em uma introdução rapisódica seguida de um tema e quatro variações, terminando numa coda. As dificuldades técnicas são enfatizadas, incluindo passagens com escalas e arpejos rápidos e cordas duplas. A extensão vai até a quinta posição e exige um nível técnico avançado.

Campagnoli, Bartolomeo (1751-1827) - 41 Caprices pour l'Alto Viola. Oeuvre 22.

O violinista italiano Bartolomeo Campagnoli com estudou com Paolo Guastarobba e Pietro Nardini, na escola de Giuseppe Tartini. Teve uma carreira de sucesso na Itália antes de se mudar para Dresden em 1780, para assumir a direção da Capela do Duque de Courland. Foi spalla e maestro da orquestra Gewandhaus em Leipzig de 1787 a 1818. Escreveu obras pedagógicas para violino e viola. Os 41 
Caprichos foram publicados pela primeira vez em 1805 e ainda permanecem como material básico de estudo do violista. Em nível similar aos estudos para violino de Kreutzer e Fiorillo, fornecem um estudo progressivo e completo em técnica de arco e posições de mão esquerda. Contém desafios técnicos e musicais.

Cavallini, Eugenio. (1806-1881) - 24 Exercices pour Alto Seul. Publicado como a terceira parte do Méthode d'Alto de J. Martinn. Ed. Théophile Laforge.

Estes estudos foram publicados pela primeira vez em Milão em 1860. Os primeiros estudos são curtos e elementares, exigindo apenas uma utilização modesta da terceira posição. O avanço é rápido, abordando uma grande variedade de arcadas na corda e fora da corda e dificuldades causadas pelas mudanças de corda. Estes estudos fornecem uma prática extensiva nas primeiras cinco posições, com diversas passagens permanecendo na quinta posição por grandes períodos. Entretanto esta posição é raramente excedida. Também fornecem uma prática extensiva na meia posição, e também são incluídos estudos de trinados e cordas duplas. Os últimos quatro estudos, peças mais longas compostas para funcionar também como obras de concerto, são de nível técnico similar aos estudos de Rode.

Hoffmeister, Franz Anton (1754-1812) - Études pour Alto Viola. Dois volumes. Leipzig: C. F. Peters, Bureau de Musique, n.d.

Além de ter sido um compositor muito prolífico, Hoffmeister foi um dos campeões de publicação em sua época. Seu concerto para viola em ré maior ainda hoje faz parte do repertório padrão dos violistas. Os doze estudos foram compostos para funcionar também como peças de concerto. Alguns dos estudos são em forma sonata, outros minuetos, outros em forma de tema com variações. O compositor incorpora habilidades técnicas que podem ser encontradas no concerto clássico padrão. Há passagens incluindo cordas duplas, arpejos e escalas em detaché e arcadas ligadas. A quinta posição aparece com freqüência, mas raramente excedida. O nível técnico pode ser comparado com os caprichos mais fáceis de Rode.

Rolla, Alessandro (1757-1841) - Esercizio ed Arpeggio per Viola, Opera Postuma. Rolla, Alessandro. Frammenti d'Opera di Studio per La Viola, Opera Postuma. 
Alessandro Rolla foi um dos violinistas e violistas italianos mais famosos de sua época. Foi primeiro violino e maestro da orquestra La Scalla em Milão de 1803 a 1833 e professor de violino e viola no novo Conservatório de Milão de 1808 a 1835. Foi professor de Cavallini e, possivelmente, por um breve período, de Paganini. Compôs pelo menos quinze concertos para viola. Estes estudos incluem passagens extensas de escalas e arpejos até a quinta posição, passagens freqüentes de cordas duplas, staccato com arco para cima e mudanças de cordas. Exigem nível técnico avançado.

\section{Método de Base atual}

Volmer, Berta - Bratschenschle, 2 vol.

Método de iniciação à viola dividido em dois volumes. Contém escalas e mudança de posição, além de músicas curtas para uma ou duas violas com nível progressivo de dificuldade.

O primeiro volume é iniciado com uma introdução, discorrendo sobre os princípios básicos da viola - clave de do, notação, posição. Os exercícios iniciam nas cordas soltas, adicionando então a mão esquerda, aumentando o grau de dificuldade dos exercícios. O segundo volume inicia no ponto onde termina o primeiro volume, abordando as mudanças de posição até a quinta posição, cordas duplas, ornamentos e vibrato. A aplicação da técnica ao final se dá em estudos de Wohlfhart, Kayser, Kreutzer e o Moto Perpétuo de Paganini, e duetos. 


\section{ANEXO B - CONTEÚDO PROGRAMÁTICO}

Curso: Viola

Duração: 8 Semestres

\section{1은 Semestre:}

Mão esquerda: Exercícios de flexibilidade e equilíbrio dos dedos e articulações, pressão adequada dos dedos para articulação, mudança de posição, afinação, posição fixa até a $3^{a}$ posição, vibrato, cordas duplas e acordes na 1 a posição. Mão direita: Exercícios de flexibilidade dos dedos e articulações para produção de som de qualidade, consciência do peso do braço para produção de som, distribuição de arco, mudanças de corda, golpes de arco - detaché, martelé, staccato, legato, combinação de arcadas, dinâmicas, cordas duplas na $1^{1 \underline{a}}$ posição, acordes na $1^{\underline{a}}$ posição.

\section{Prática:}

- Estudos: Kayser, Kreutzer, Bruni, Campagnoli, Fiorillo

- Exercícios: Sevcik op.1 parte 1, op.8, op.2

- Escalas: Flesch, Mogill - Scale Studies

- Repertório: Telemann - Concerto em sol maior, Eccles - Sonata, J. S. Bach - Suíte n. 1 ou Suíte n.3, Fiocco - Allegro 


\section{2o Semestre:}

Mão Esquerda: Exercícios de golpes de arco na corda e fora da corda - detaché, martelé, staccato, spiccatto no ponto de equilíbrio do arco.

Mão direita: Exercícios de cordas duplas até a $3^{\underline{a}}$ posição, acordes de três e quatro notas na 1aㅡ posição, mudança até a 4⿳亠丷a posição, posição fixa até a 4⿳亠丷a posição, harmônicos naturais, trinados e mordentes.

\section{Prática:}

- Estudos: Kayser, Kreutzer, Bruni, Campagnoli, Fiorillo, Mazas - livro 1

- Exercícios: Sevcik op.1 parte 1, op.8, op.2, op.9

- Escalas: Flesch, Mogill - Scale Studies

- Repertório: Telemann - Concerto em sol maior, Eccles - Sonata, J. S. Bach - Suíte n.1 ou Suíte n.3, Fiocco - Allegro, Marcello - Sonata em do maior, ré maior ou mi menor, Haendel - Sonata em sol menor, Sitt - Autum Leaves, Liszt - Romance Oublieé, Guerra Peixe - 3 Peças 


\section{3o Semestre:}

Mão direita: Golpes de arco: detaché, martelé, staccato, legato - oito ou mais notas por arcada, spiccatto - em diferentes partes do arco e em diferentes velocidades, aplicação dos diferentes fatores que compõem a emissão de som - pressão, velocidade e ponto de contato, sonoridade nas cordas duplas, acordes de três e quatro notas entre a $1^{\underline{a}}$ e a $3^{\underline{a}}$ posições.

Mão esquerda: mudança de posição - ascendente e descendente em qualquer posição, correta utilização do braço esquerdo no registro agudo do instrumento, posição fixa - da $1^{\underline{a}}$ a $5^{\underline{a}}$, velocidade dos dedos na $1^{\underline{a}}$ posição, cordas duplas terças, sextas e oitavas e mudanças de posição, harmônicos naturais com $3^{\circ}$ e $4^{\circ}$ dedos, extensão do $4^{\circ}$ dedo.

\section{Prática:}

- Estudos: Kreutzer, Bruni, Campagnoli, Rode, Fiorillo, Hoffmeister, Cavallini, Mazas - livro 1

- Exercícios: Sevcik op.1 parte 1, op.8, op.2, op.9

- Escalas: Flesch, Mogill - Scale System

- Repertório: J. C. Bach - Concerto em do menor, J. S. Bach - Suítes n. 1, 2 ou 3 para viola solo, Zelter - Concerto em ré maior, Glazunov - Elegia, Telemann Fantasias para viola solo, Fiocco - Allegro, Marcello - Sonata em do maior, ré maior ou mi menor, Haendel - Sonata em sol menor, Guerra Peixe - 3 Peças, Guerra Peixe - Bilhete de um Jogral 


\section{4ํㅗㄹ Semestre}

Mão direita: Golpes de arco: detaché, martele, staccato, legato - mais de 8 notas por arco, spiccatto - em diferentes partes do arco e em diferentes velocidades, sautillé, combinação de diferentes arcadas em velocidades diversas e em diferentes partes do arco, aplicação dos fatores que compõem a emissão de som - pressão, velocidade e ponto de contato com a premissa de produção de som de qualidade em todos os pontos do arco, acordes de três e quatro notas e mudanças de posição - acordes invertidos.

Mão esquerda: posição fixa da $1^{\text {a }}$ a $5^{\text {a }}$ posição, velocidade dos dedos em posições fixas e nas mudanças de posição, digitação de cromatismos, cordas duplas em intervalos de terças, sextas, oitavas, quartas e quintas e com mudanças de posição, harmônicos naturais e artificiais, extensões e reduções.

\section{Prática:}

- Estudos: Kreutzer, Bruni, Campagnoli, Rode, Hoffmeister, Cavallini, Mazas - livro 1

- Exercícios: Sevcik op.1 parte 1, op.8, op.2, op.9

- Escalas: Flesch, Mogill - Scale System

- Repertório: J. C. Bach - Concerto em do menor, J. S. Bach - Suítes n. 1, 2 ou 3 para viola solo, Zelter - Concerto em ré maior, Glazunov - Elegia, Telemann Fantasias para viola solo, Marcello - Sonata em do maior, ré maior ou mi menor, Guerra Peixe - 3 Peças, Guerra Peixe - Bilhete de um Jogral, Schumann Märchenbilder, Bruch - Kol Nidrei, Fauré - Elegia, Hummel - Fantasia, Hindemith Trauermusik. 


\section{5을 Semestre}

Mão direita: Golpes de arco: detaché, martele, staccato, legato - mais de 8 notas por arco, spiccatto - em diferentes partes do arco e em diferentes velocidades, sautillé, combinação de diferentes arcadas em velocidades diversas e em diferentes partes do arco, ricoché em uma corda, collé, tremolo, ataques - acento, sfz, fp.

Mão esquerda: flexibilidade e equilíbrio dos dedos e articulações, diferenciação entre afinação melódica e harmônica - cordas duplas e acordes, vibrato - aplicação correta e coerente dos diferentes tipos de vibrato de acordo com o repertório.

\section{Prática:}

- Estudos: Campagnoli, Rode, Hoffmeister, Cavallini, Dont, Mazas - livro2

- Exercícios: Sevcik op.1, op.8, op.2, op.9

- Escalas: Flesch, Mogill - Scale System

- Repertório: J. C. Bach - Concerto em do menor, J. S. Bach - Suítes n. 1, 2 ou 3 para viola solo, Zelter - Concerto em ré maior, Glazunov - Elegia, Telemann Fantasias para viola solo, Marcello - Sonata em do maior, ré maior ou mi menor, Guerra Peixe - 3 Peças, Guerra Peixe - Bilhete de um Jogral, Schumann Märchenbilder, Bruch - Kol Nidrei, Fauré - Elegia, Hummel - Fantasia, Hindemith Trauermusik, Villa-Lobos - O Canto do Cisne Negro, Max Reger - Três Suites para Viola Solo 


\section{6을 Semestre}

Mão direita: Golpes de arco: detaché, martele, staccato, legato - mais de 8 notas por arco, spiccatto - em diferentes partes do arco e em diferentes velocidades, sautillé, combinação de diferentes arcadas em velocidades diversas e em diferentes partes do arco, collé, tremolo, ataques - acento, sfz, fp., ricoché com mudança de corda. Mão esquerda: Scordatura

\section{Prática:}

- Estudos: Campagnoli, Rode, Hoffmeister, Cavallini, Mazas - vol.2, Dont, Gaviniès

- Exercícios: Sevcik op.1, op.8, op.2, op.9

- Escalas: Flesch, Mogill - Advanced Scales and Double Stops

- Repertório: J. S. Bach - Suítes n. 4, 5 ou 6 para viola solo, Guerra Peixe - Bilhete de um Jogral, Schumann - Märchenbilder, Stamitz - Concerto em Ré Maior, Hoffmeister - Concerto em Ré Maior, Bruch - Romance, Schumann Märchenbilder, Schumann - Adagio e Allegro, Radamés Gnattali - Brasiliana para viola, Brahms - Sonatas op. 120 para viola e piano, Paganini - Moto Perpétuo, Bloch - Suíte Hebraica 


\section{7은 Semestre}

A partir deste semestre, aplicação e aperfeiçoamento de toda a técnica adquirida até este ponto.

\section{Prática:}

- Estudos: Campagnoli, Rode, Hoffmeister, Cavallini, Mazas - vol.2, Dont, Gaviniès

- Exercícios: Sevcik op.1, op.8, op.2, op.9

- Escalas: Flesch, Mogill - Advanced Scales and Double Stops

- Repertório: J. S. Bach - Suítes n. 4, 5 ou 6 para viola solo, Stamitz - Concerto em Ré Maior, Hoffmeister - Concerto em Ré Maior, Bruch - Romance, Radamés Gnattali - Brasiliana para viola, Brahms - Sonatas op. 120 para viola e piano, Walton - Concerto, Schubert - Sontata "Arpeggione", Enesco - Concertpiece, Weber - Andante e Rondó Ungarese, Guarnieri, C. - Sonata 


\section{8o Semestre}

Aplicação e aperfeiçoamento de toda a técnica adquirida até este ponto.

\section{Prática:}

- Estudos: Campagnoli, Rode, Hoffmeister, Cavallini, Mazas - vol.2, Dont, Gaviniès

- Exercícios: Sevcik op.1, op.8, op.2, op.9

- Escalas: Flesch, Mogill - Advanced Scales and Double Stops

- Repertório: J. S. Bach - Suítes n. 4, 5 ou 6 para viola solo, Radamés Gnattali Brasiliana para viola solo, Brahms - Sonatas op.120 para viola e piano, Walton Concerto, Schubert - Sontata "Arpeggione", Enesco - Concertpiece, Hindemith Sonata op. 11 n.4, Hindemith - Sonata op. 25 n.1, Bartók - Concerto para viola, Rebecca Clarke - Sonata, Shostakovich - Sonata, Stravinsky - Elegia para Viola Solo

\section{Recital de Formatura}

- 1 obra para viola solo

- 1 obra do período barroco

- 1 obra do período clássico

- 1 obra do período romântico

- 1 obra do período contemporâneo

- 1 obra de compositor brasileiro 


\section{Bibliografia Básica}

\section{Estudos e Caprichos}

Campagnoli - 41 Capricci Op.22 per Viola.

Dont, Jacob - Etüden und Capricen Op.35.

Flesch, Carl - Das Scale System.

Gaviniès, Pierre - Les 24 Matinées per viola.

Kayser - 36 Studies.

Kreutzer, Rudolph - 42 Studies or Caprices

Mazas - Estudes Speciales for viola vol. 1 e 2

Mogill - Advanced Scales and Double Stops for viola

Mogill - Scale Studies for viola

Rode, Pierre. 24 - Caprices for the Viola.

Sevcik - Op.1 School of Violin Technique (transcribed for viola)

Sevcik - Op.2 School of Bowing Technique.

Secvik - Op.8 School of Shifting

Sevcik - Op.9 School Double Strings

\section{Repertório}

Bach, J. C. - Concerto em do menor

Bartók - Concerto para viola

Bloch - Suíte Hebraica

Brahms - Sonatas op. 120 para viola e piano.

Brahms - Sonatensatz

Bruch - Kol Nidrei

Bruch - Romance

Eccles - Sonata

Enesco - Concertpiece

Fauré - Elegia

Fiocco - Allegro

Glazunov - Elegia

Guarnieri, C. - Sonata n.1

Guerra Peixe - 3 Peças 
Haendel - Sonata em sol menor

Hindemith - Sonata op. 11 n.4

Hindemith - Trauermusik

Hoffmeister - Concerto em Ré Maior

Hummel - Fantasia

Liszt - Romance Oublieé

Marcello - Sonata em do maior

Marcello - Sonata em ré maior

Marcello - Sonata em mi menor

Mozart - Sinfonia Concertante for Violin and Viola K,320d

Paganini - Moto Perpétuo

Radamés Gnattali - Brasiliana para viola

Rebecca Clarke - Sonata para viola e piano

Schubert - Sontata "Arpeggione"

Schumann - Adagio e Allegro

Schumann - Märchenbilder

Shostakovich - Sonata op. 147

Sitt - Autum Leaves

Stamitz - Concerto em Ré Maior

Telemann - Concerto em sol maior

Villa-Lobos - O Canto do Cisne Negro

Walton - Concerto para viola

Weber - Andante e Rondó Ungarese

Zelter - Concerto em ré maior

\section{Viola Solo}

Bach, J. S. - Seis Suítes

Guerra Peixe - Bilhete de um Jogral

Hindemith - Sonata op. 25 n. 1

Max Reger - Três Suites para Viola Solo

Stravinsky - Elegia para Viola Solo

Telemann - 12 Fantasias para viola solo 


\section{Bibliografia Complementar}

AUER, Leopold. Violin Playing as I teach It. Londres: Gerald Duckworth and Company Ltda., 1921

BARRETT, Henry, The Viola: Complete Guide for Teachers and Students, $2^{\text {nd }}$ ed. Rev. and ed. Tuscaloosa: The University of Alabama Press, 1978

BOYDEN, David e WOODWARD, Ann. Violin Family, Ed. Stanley Sadie. The Grove Musical Instrument Series. New York: W.W.Norton and Co. 1989

BOYDEN, David. History of Violin Playing. London: Macmillan. 1989

DALTON, David. Playing the Viola - Conversations with William Primrose. Nova Iorque: Oxford University Press, 2003

FLESCH, Carl. Basic Studies for Viola. New York: Carl Fiscer, Inc., 1990

FLESCH, Carl. The Art of Violin Playing. 2 vol. Nova lorque: Carl Fischer Inc., 1930

GALAMIAN, Ivan and NEUMANN, Frederick, Contemporary Violin Technique, 2 vol. New York: Galaxy Music Corporation, 1966

Principles of Violin Playing and Teaching. Englewood Cliffs, Nova Jersei: Prentice Hall, 1962

KIEVMAN, Louis. Practicing the Viola Mentally-Phisically. California: Kelton Publications. 1969

MENUHIN, Yehud e PRIMROSE, William. Violin and Viola. Yehudi Menuhin Music Guides. London: Kahn \& Averill, 2008

NELSON, Sheila M. The Violin and Viola: History, Structure, Techniques. Nova Iorque: Dover Publications, 2003 
PRIMROSE, William. A Walk in the North Side: Memoirs of a Violist. Provo, Utah:

Brigham Young University Press, 1978

REITER, Emmanuela. Karen Tuttle's Heritage: The Theory and Prectice of Coordination. Boston: Emmanuela Reiter, 2008

RILEY Maurice. The History of the Viola. Michigan:Braun-Brumfield.1980

\section{Artigo:}

WHITE-SMITH, Juliet. From Violin to Viola. American String Teacher Magazine, fevereiro 2000. 